LEONARDO PEREIRA MESQUITA

Avaliação da resposta imune e inflamatória na encefalite experimentalmente induzida em camundongos pela infecção pelo vírus da estomatite vesicular e herpesvírus bovino tipo 5 


\section{LEONARDO PEREIRA MESQUITA}

Avaliação da resposta imune e inflamatória na encefalite experimentalmente induzida em camundongos pela infecção pelo vírus da estomatite vesicular e herpesvírus bovino tipo 5

Tese apresentada ao Programa de PósGraduação em Patologia Experimental e Comparada da Faculdade de Medicina Veterinária e Zootecnia da Universidade de São Paulo para a obtenção do título de Doutor em Ciências

Departamento:

Patologia

Área de Concentração:

Patologia Experimental e Comparada

Orientador:

Prof. Dr. Paulo César Maiorka

São Paulo 
Autorizo a reprodução parcial ou total desta obra, para fins acadêmicos, desde que citada a fonte.

\section{DADOS INTERNACIONAIS DE CATALOGAÇÃO NA PUBLICAÇÃO}

(Biblioteca Virginie Buff D’Ápice da Faculdade de Medicina Veterinária e Zootecnia da Universidade de São Paulo)

Mesquita, Leonardo Pereira

Avaliação da resposta imune e inflamatória na encefalite experimentalmente induzida em camundongos pela infecção pelo vírus da estomatite vesicular e herpesvírus bovino tipo 5 / Leonardo Pereira Mesquita. -- 2016.

$95 \mathrm{f}$ : : il.

Tese (Doutorado) - Universidade de São Paulo. Faculdade de Medicina Veterinária e Zootecnia. Departamento de Patologia, São Paulo, 2016.

Programa de Pós-Graduação: Patologia Experimental e Comparada.

Área de concentração: Patologia Experimental e Comparada.

Orientador: Prof. Dr. Paulo César Maiorka.

1. Citocinas. 2. Neuro-inflamação. 3. Quimiocinas. 4. Sistema nervoso central. I. Título. 
São Paulo, 27 de abril de 2015

\section{CERTIFICADO}

Certificamos que o Projeto intitulado "Avaliação da Resposta Imune e Inflamatória no Sistema Nervoso Central Causada pelo Herpesvírus Bovino tipo 5 (BoHV-5) em camundongos BALB/c.", protocolado sob o CEUA n 3485200814, utilizando 216 Camundongos isogênicos (216 femeas), sob a responsabilidade de Paulo César Maiorka, foi aprovado na reunião de 17/09/2014, e está de acordo com os princípios éticos de experimentação animal da Comissão de Ética no Uso de Animais da Faculdade de Medicina Veterinária e Zootecnia da Universidade de São Paulo.

We certify that the Research "Inflammatory and immune response in the central nervous system caused by bovine herpesvirus type 5 (BoHV-5) in Balb/c mice ", protocol number CEUA 3485200814, utilizing 216 Isogenics mice (216 females), under the responsibility Paulo César Maiorka, was approved in the meeting of day 09/17/2014, and agree with Ethical Principles in Animal Research adopted by Ethic Committee on Animal Use of the School of Veterinary Medicine and Animal Science of the University of São Paulo.

Atenciosamente,

Jesios \&antain

Profa. Dra. Denise Tabacchi Fantoni

Presidente da Comissão de Ética no Uso de Animais

Faculdade de Medicina Veterinária e Zootecnia

Universidade de São Paulo 


\section{FOLHA DE AVALIAÇÃO}

Autor: MESQUITA, Leonardo Pereira

Título: Avaliação da resposta imune e inflamatória na encefalite experimentalmente induzida em camundongos pela infecção pelo vírus da estomatite vesicular e herpesvírus bovino tipo 5

Tese apresentada ao Programa de PósGraduação em Patologia Experimental e Comparada da Faculdade de Medicina Veterinária e Zootecnia da Universidade de São Paulo para a obtenção do título de Doutor em Ciências

Data:

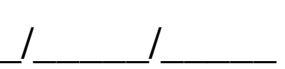

\section{Banca Examinadora}

Prof. Dr.

Instituição: Julgamento:

Prof. Dr.

Instituição: Julgamento:

Prof. Dr.

Instituição: Julgamento:

Prof. Dr. Instituição: Julgamento:

Prof. Dr. Instituição: Julgamento: 
Aos meu pais, Eduardo e Maria do Carmo, à minha irmã Luciana, e à minha mulher Laís, dedico. 


\section{AGRADECIMENTOS}

Ao professor e amigo Paulo C. Maiorka, pela orientação, paciência, e dificuldades compartilhadas.

À professora Cláudia Mori e prof. Enio Mori, por sua imprescindível ajuda durante a execução do projeto.

Aos membros da banca, pela disponibilidade e contribuições indispensáveis, especialmente a profa. Mary S. Varaschin, que me ajudou desde o início na patologia animal.

A todos os professores do VPT, especialmente à prof. Cristina Massoco por ter cedido o laboratório de farmacologia para sua utilização.

Ao pessoal do Instituto Biológico, laboratório de Viroses de Bovídeos, especialmente a profa. Maristela Pituco, a qual foi fundamental para realização do trabalho, e à Márcia, sempre disposta a ajudar.

Ao pessoal do laboratório de ornitopatologia, do prof. Antônio Piantino, especialmente ao Luis, pela ajuda na execução deste trabalho.

À prof. Mayra E. O. D’Avila Assumpção, do departamento de reprodução animal, por ter permitido a realização da quantificação de ácidos nucleicos.

Aos professores e residentes do Department of Pathology, University of Georgia, EUA, especialmente à profa. Elizabeth Howerth, que me orientou nos EUA, com ela muito aprendi, muito obrigado.

À profa. Corrie C Brown, que me acolheu muito bem nos EUA, não tenho palavras para descrever sua hospitalidade, assim como meu amigo Nanda.

Aos amigos aqui presentes, Dennis, Luis e Rafael, e distantes Fábio e Jean, pelo companheirismo e diversão compartilhados, muito obrigado. $\mathrm{E}$ a todos outros amigos e amigas não citados aqui, mas igualmente importantes.

A todos os colegas de trabalho Adriana, Fernanda, Thaís Hamilton, Thaís Gamon, Paloma, Andressa, Vera e Elena que de alguma forma colaboraram.

Aos vários funcionários do VPT, especialmente o Nelsinho, D. Idalina, Mauro, Luciana, Buga, Cláudio, Herculano, Vagner e Nicolle.

Aos funcionários da biblioteca FMVZ-USP, especialmente à Elza Faquim, pela revisão do presente trabalho. 
À FAPESP, pela concessão da bolsa de estudos de doutorado (processo 2013/00629-6) e BEPE (processo 2014/20631-8). 


\section{RESUMO}

MESQUITA, L. P. Avaliação da resposta imune e inflamatória na encefalite experimentalmente induzida em camundongos pela infecção pelo vírus da estomatite vesicular e herpesvírus bovino tipo 5 [Evaluation of immune and inflammatory responses in experimentally induced encephalitis in mice caused by vesicular stomatitis virus and bovine herpesvirus type 5]. 2016. $95 \mathrm{f}$. Tese (Doutorado em Ciências) - Faculdade de Medicina Veterinária e Zootecnia, Universidade de São Paulo, São Paulo, 2016.

O presente trabalho compreende o estudo da resposta imune e inflamatória no sistema nervoso central (SNC) de camundongos ou ratos-veadeiros (Peromyscus maniculatus) frente a infecção por dois diferentes tipos de vírus neurotrópicos, o vírus da estomatite vesicular (VEV) e o herpesvírus bovino tipo 5 (BoHV-5). Na primeira etapa, foi avaliada a função das células residentes do SNC no tocante à expressão de quimiocinas durante a infecção pelo VEV em ratos-veadeiros. No presente estudo, durante a encefalite causada pelo vírus da estomatite vesicular sorotipo New Jersey (VEVNJ) em ratos-veadeiros, as quimiocinas RANTES e MCP-1 foram expressas somente no bulbo olfatório (BO), local onde o vírus estava restrito. A expressão de quimiocinas foi seguida de um influxo de células inflamatórias no BO tardiamente no curso da doença aguda. A quimiocina RANTES foi expressa por neurônios, astrócitos e micróglia, ao passo que MCP-1 foi expressa por neurônios e astrócitos. Embora os astrócitos e a micróglia tenham respondido à infecção pelo VEVNJ ao expressarem quimiocinas, os neurônios foram o principal tipo celular infectado pelo vírus. Portanto, os neurônios infectados podem exercer um papel crucial na geração da resposta imune no BO. A sinalização entre neurônios e outras células residentes do SNC muito provavelmente é o mecanismo pelo qual os astrócitos e micróglia são ativados durante a encefalite causada pelo VEVNJ. Os resultados aqui apresentados, também indicam que a expressão de RANTES e MCP-1 no BO de ratos-veadeiros infectados pelo VEVNJ pode ajudar a prevenir a disseminação do vírus para outras áreas do SNC. Na segunda etapa, foi avaliada a susceptibilidade de camundongos isogênicos BALB/c frente à infecção pelo BoHV-5 em camundongos isogênicos BALB/c em diferentes dias pós-inoculação (DPI). O BoHV-5 quando inoculado pela via intracraniana foi capaz de infectar e se replicar no SNC de camundongos BALB/c. Entretanto, até o momento avaliado (15 DPI), os 
animais sobreviveram a infecção sem apresentar sinais neurológicos evidentes. A infecção foi acompanhada de uma resposta imune do tipo Th1 importante, com expressão significativa das citocinas IFN- $\gamma$ e TNF- $\alpha$, e quimiocina CCL-2. A expressão das citocinas e quimiocinas se deu principalmente no início da infecção (3 e 4 DPI), a qual foi seguida por uma meningo-encefalite com manguitos perivasculares e periventriculite, compostas predominantemente por macrófagos e linfócitos. Após a expressão significativa das citocinas e quimiocina, os animais foram capazes de debelar a infecção aguda, uma vez que partículas virais viáveis não foram detectadas após o 6 DPI. Entretanto, o BoHV-5 foi capaz de infectar o gânglio trigeminal, uma vez que grande quantidade de DNA de BoHV-5 foi detectada no $3 \mathrm{DPI}$, o que foi confirmado pela presença de antígenos virais no citoplasma de neurônios do gânglio trigeminal de camundongos BALB/c infectados.

Palavras-chave: Citocinas. Neuro-inflamação. Quimiocinas. Sistema nervoso central. 


\begin{abstract}
MESQUITA, L. P. Evaluation of immune and inflammatory responses in experimentally induced encephalitis in mice caused by vesicular stomatitis virus and bovine herpesvirus type 5. [Avaliação da resposta imune e inflamatória na encefalite experimentalmente induzida em camundongos pela infecção pelo vírus da estomatite vesicular e herpesvírus bovino tipo 5]. 2016. 95 f. Tese (Doutorado em Ciências) - Faculdade de Medicina Veterinária e Zootecnia, Universidade de São Paulo, São Paulo, 2016.
\end{abstract}

The present work comprises the study of immune and inflammatory responses in the central nervous system (CNS) of mice or deer mice (Peromyscus maniculatus) during infection by two different neurotropic viruses, the vesicular stomatitis virus (VSV) and bovine herpesvirus type 5 (BoHV-5). In the first part, the role of CNS resident cells regarding chemokine expression in deer mice infected with VSV was evaluated. Here, we demonstrated that during vesicular stomatitis New Jersey virus (VSNJV) encephalitis in deer mice, chemokines RANTES and MCP-1 are expressed only in the olfactory bulb $(\mathrm{OB})$, where the virus was restricted. This chemokine expression was followed by the influx of inflammatory cells to the OB later in the course of acute disease. Neurons, astrocytes and microglia expressed RANTES, whereas MCP-1 was expressed by neurons and astrocytes. Although astrocytes and microglia responded to VSNJV infection by expressing chemokines, neurons were the predominantly infected cell type. Therefore, infected neurons may have a critical role in initiating an immune response in the OB. The signaling between neurons and other CNS resident cells is most likely the mechanism by which astrocytes and microglia are activated during the course of VSV encephalitis. Our results also indicate that the expression of RANTES and MCP-1 in the OB of deer mice infected with VSNJV might help prevent the spread of VSNJV to other areas of CNS. In the second part of the study, the susceptibility of isogenic BALB/c mice to BoHV-5 infection was evaluated in different days post-inoculation (DPI). BoHV-5, when inoculated through intracranial route, was able to infect and replicate within the CNS of BALB/C mice. However, until the evaluated time (15 DPI), the mice was able to survive without showing prominent neurological signs. The infection was accompanied by an important Th1 immune response, with a significant expression of the cytokines IFN-Y 
and TNF- $\alpha$, and chemokine CCL-2. The expression of these cytokines and chemokines was detected mainly on the early course of infection ( 3 and $4 \mathrm{DPI}$ ), and was followed by a meningoencephalitis with perivascular cuffing and periventriculitis, composed mainly by macrophages and lymphocytes. After the expression of cytokines and chemokine, the mice were able to curb BoHV-5 acute infection, since viable viral particles were not detected after 6 DPI. However, BoHV-5 was able to infect the trigeminal ganglia, since a large number of BoHV-5 DNA copies was detected on $3 \mathrm{DPI}$, which was confirmed by the presence of viral antigens within the cytoplasm of neurons in the trigeminal ganglia of infected BALB/c mice.

Keywords: Cytokines. Neuroinflammation. Chemokines. Central nervous system. 
2 CINÉTICA DA EXPRESSÃO DE RANTES E MCP-1 NO SISTEMA NERVOSO CENTRAL DE RATOS-VEADEIROS (Peromyscus maniculatus) INFECTADOS PELO VíRUS DA ESTOMATITE

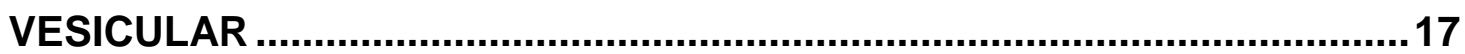

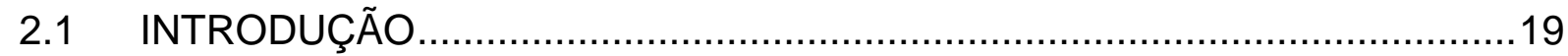

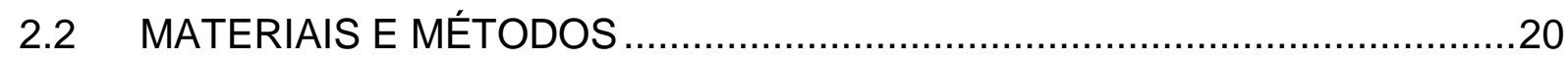

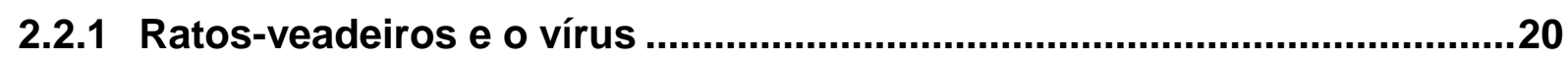

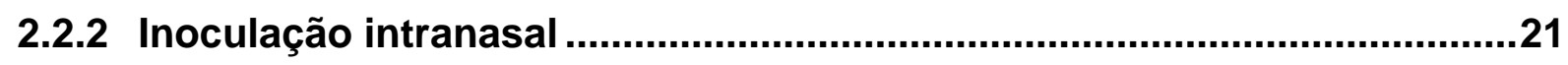

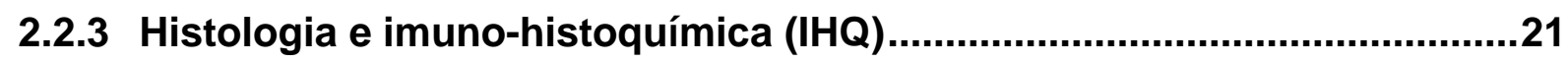

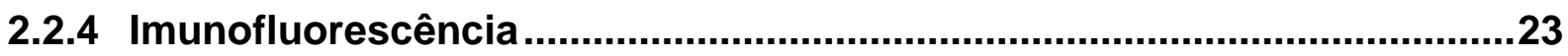

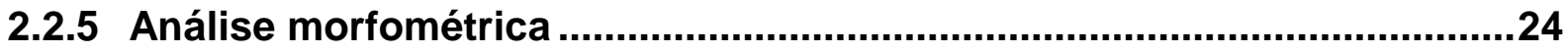

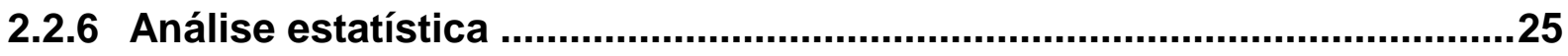

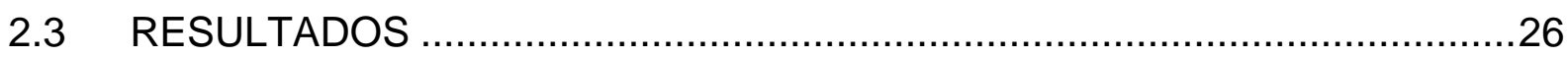

2.3.1 Expressão de RANTES e MCP-1 no SNC de ratos-veadeiros infectados com VEVNJ..........................................................................26

2.3.2 Expressão de RANTES e MCP-1 em células residentes do SNC de ratos-veadeiros infectados com VEVNJ ...............................................29

2.3.3 Distribuição de VEVNJ Colorado no SNC de ratos-veadeiros

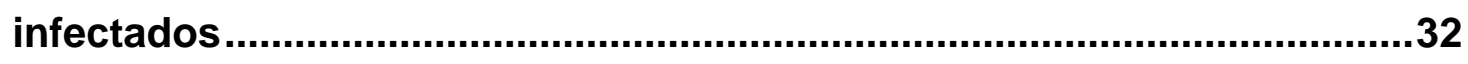

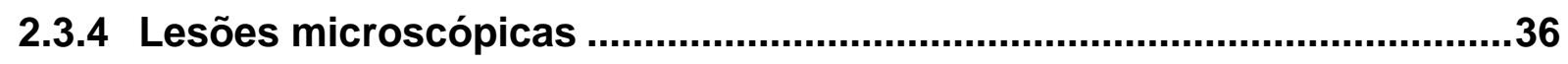

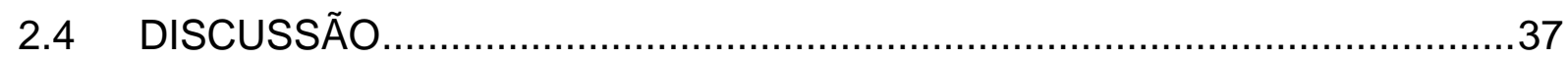

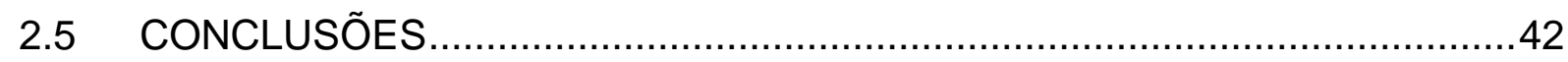

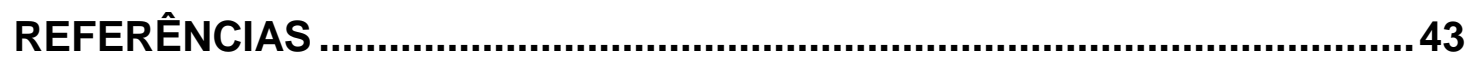

APÊNDICE

3 AVALIAÇÃO DA RESPOSTA IMUNE E INFLAMATÓRIA NO SISTEMA NERVOSO CENTRAL DE CAMUNDONGOS INFECTADOS PELO HERPESVÍRUS BOVINO TIPO 5 (BoHV-5)....................................59

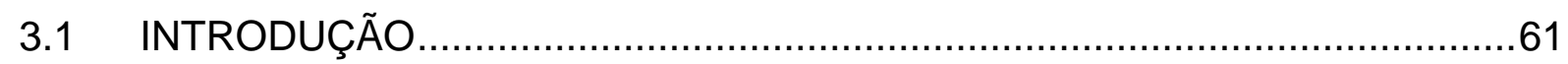

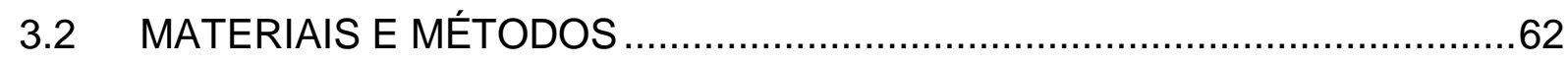

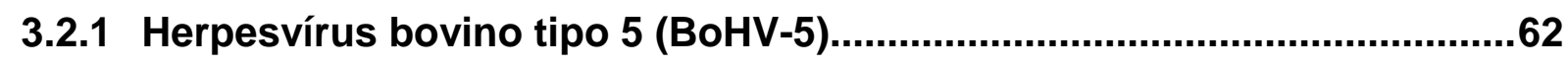


3.2.2 Camundongos e delineamento experimental.........................................63

3.2.3 Necropsia, coleta de material e perfusão transcardíaca ..........................65

3.2.4 Análise histológica e imuno-histoquímica (IHQ) ....................................65

3.2.5 Extração do RNA, transcrição reversa para síntese do DNA complementar (cDNA) e qPCR para quantificação de citocinas e quimiocina pró-inflamatórias................................................................67

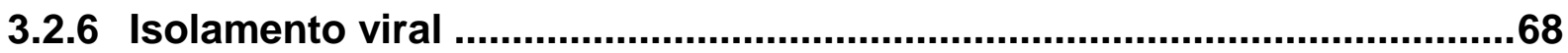

3.2.7 Detecção do BoHV-5 pela PCR quantitativa (qPCR) absoluta em

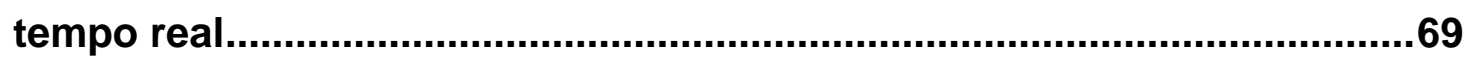

3.2.8 Extração de DNA para posterior detecção do BoHV-5 pela PCR quantitativa (qPCR) em tempo real ...........................................................71

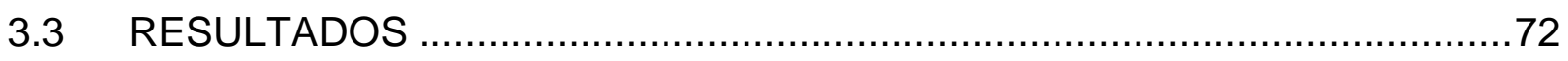

3.3.1 Resultado da infecção - sinais clínicos ………......................................72

3.3.2 Análise histológica e imuno-histoquímica (IHQ) .....................................72

3.3.3 Expressão gênica de citocinas e quimiocina pró-inflamatórias................79

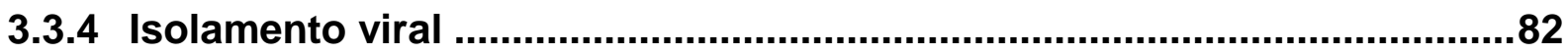

3.3.5 Quantificação absoluta de BoHV-5 por qPCR em tempo real..................83

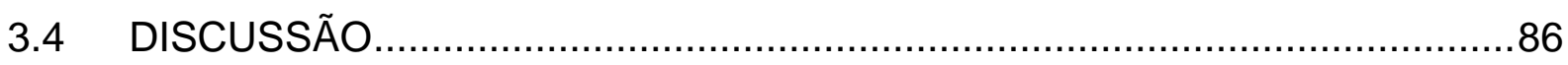

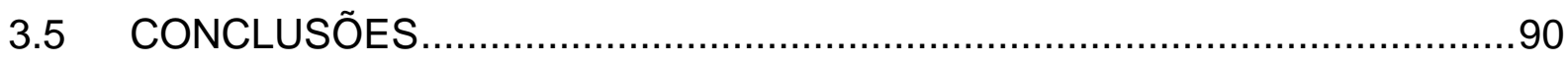

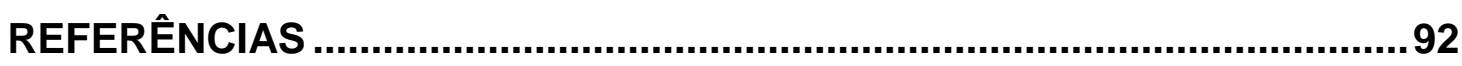

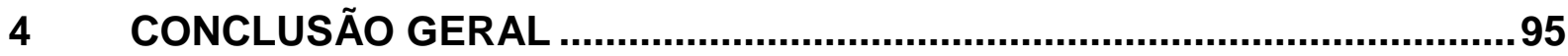




\section{INTRODUÇÃO GERAL}

O presente trabalho compreende o estudo da resposta imune e inflamatória no sistema nervoso central (SNC) de camundongos ou ratos-veadeiros (Peromyscus maniculatus) frente a infecção por dois diferentes tipos de vírus neurotrópicos, o vírus da estomatite vesicular (VEV) e o herpesvírus bovino tipo 5 (BoHV-5). Portanto, o presente trabalho será divido e apresentado na forma de artigos científicos de acordo com o tipo de agente etiológico (VEV ou BoHV-5) e modelos animais (camundongos isogênicos BALB/c ou ratos-veadeiros) estudados.

Primeiramente, no capítulo 2, será apresentado um artigo científico, intitulado "Cinética da expressão de RANTES e MCP-1 no sistema nervoso central de ratosveadeiros (Peromyscus maniculatus) infectados pelo vírus da estomatite vesicular". Este estudo teve como objetivo avaliar a cinética de expressão de quimiocinas no SNC de ratos-veadeiros infectados pela via intranasal com o VEV, bem como avaliar a participação das células gliais (neurônios, astrócitos e micróglia) no desenvolvimento da encefalite. A expressão de quimiocinas foi correlacionada com a distribuição viral e com o infiltrado inflamatório no SNC. Neste estudo foi realizada a expressão por meio de imuno-histoquímica das quimiocinas: chemokine monocyte chemoattractant protein-1 (MCP-1) também conhecida como $\mathrm{C}-\mathrm{C}$ motif ligand 2 (CCL2), e RANTES (regulated on activation, normal T-cell expressed and secreted), também conhecida como CCL5. A participação das células gliais no tocante a expressão de quimiocinas durante a infecção pelo VEV neste modelo foi avaliada por meio de dupla-imunofluorescência (microscopia confocal).

O segundo trabalho resultante do estudo da patogênese da infecção pelo VEV em ratos-veadeiros será apresentado na forma de artigo científico. Este artigo foi publicado no periódico Veterinary Pathology e o mesmo será aqui apresentado integralmente, como foi publicado, na secção Apêndice, capítulo 2. Este artigo é intitulado de "Pathogenesis of Vesicular Stomatitis New Jersey Virus Infection in Deer Mice (Peromyscus maniculatus) Transmitted by Black Flies (Simulium vittatum)". O objetivo principal deste trabalho foi avaliar a susceptibilidade de ratosveadeiros (Peromyscus maniculatus) jovens e lactentes frente a infecção causada pelo VEV (sorotipo New Jersey) transmitido por moscas hematófagas (Simulium vittatum), bem como a habilidade destes camundongos infectados em transmitir o 
VEV para moscas não infectadas. Este artigo ressalta também a neuropatogênese da infecção causada pelo VEV descrevendo a cinética da evolução das lesões no SNC, bem como a distribuição viral. Os estudos relacionados a patogênese da infecção pelo VEV em ratos-veadeiros foram realizados em colaboração com pesquisadores do Department of Pathology, University of Georgia, Athens, GA.

$O$ presente trabalho também teve como objetivo descrever os estudos referentes a infecção pelo BoHV-5 em camundongos. Este será apresentado na forma de artigo científico, capítulo 3, o qual é intitulado de "Avaliação da resposta imune e inflamatória no sistema nervoso central de camundongos infectados pelo herpesvírus bovino tipo 5 (BoHV-5)". Este artigo teve como objetivo avaliar a resposta imune do SNC de camundongos BALB/c recém-desmamados frente a infecção pelo BoHV-5, bem como a avaliar a capacidade de neuro-invasividade, neuropatogenicidade e replicação do BoHV-5 no SNC destes camundongos. Este artigo irá elucidar alguns aspectos relacionados a infecção pelo BoHV-5 em camundongos $B A L B / c$, uma vez que não existem dados sólidos na literatura científica internacional a respeito da resposta imune e cinética da infecção nestes animais. 
Cinética da Expressão de RANTES e MCP-1 no Sistema Nervoso Central de Ratos-Veadeiros (Peromyscus maniculatus) Infectados pelo Vírus da Estomatite Vesicular 


\section{CINÉTICA DA EXPRESSÃO DE RANTES E MCP-1 NO SISTEMA NERVOSO CENTRAL DE RATOS-VEADEIROS (PEROMYSCUS MANICULATUS) INFECTADOS PELO VÍRUS DA ESTOMATITE VESICULAR}

No presente capítulo é apresentado um artigo que foi submetido ao periódico Journal of Comparative Pathology.

\section{RESUMO}

O vírus da estomatite vesicular (VEV) é um vírus bem reconhecido por causar encefalite em camundongos quando inoculado pela via intranasal. $O$ rato-veadeiro (Peromyscus maniculatus), o qual é um roedor nativo do Novo Mundo, também é susceptível a infecção pelo VEV com lesões no sistema nervoso central (SNC) similares àquelas observadas em outras espécies de roedores. As quimiocinas, tais como RANTES (CCL-5) e MCP-1 (CCL-2), as quais são importantes para quimiotaxia e ativação de células inflamatórias, são expressas durante a encefalite causada pelo VEV. Entretanto, a função das células residentes do SNC no tocante à expressão de quimiocinas é pouco caracterizada. No presente estudo, durante a encefalite causada pelo vírus da estomatite vesicular sorotipo New Jersey (VEVNJ) em ratos-veadeiros, as quimiocinas RANTES e MCP-1 foram expressas somente no bulbo olfatório (BO), local onde o vírus estava restrito. A expressão de quimiocinas foi seguida de um influxo de células inflamatórias no $B O$ tardiamente no curso da doença aguda. A quimiocina RANTES foi expressa por neurônios, astrócitos e micróglia, ao passo que MCP-1 foi expressa por neurônios e astrócitos. Embora os astrócitos e a micróglia tenham respondido à infecção pelo VEVNJ ao expressarem quimiocinas, os neurônios foram o principal tipo celular infectado pelo vírus. Portanto, os neurônios infectados podem exercer um papel crucial na geração da resposta imune no BO. A sinalização entre neurônios e outras células residentes do SNC muito provavelmente é o mecanismo pelo qual os astrócitos e micróglia são ativados durante a encefalite causada pelo VEVNJ. Os resultados aqui apresentados, também indicam que a expressão de RANTES e MCP-1 no BO de 
ratos-veadeiros infectados pelo VEVNJ possivelmente contribuem para prevenir a disseminação do vírus para outras áreas do SNC.

\section{ABSTRACT}

The vesicular stomatitis virus (VSV) is a well-known virus that causes encephalitis in mice when inoculated intranasally. The deer mouse, a native New World rodent, is also susceptible to VSV infection with similar central nervous system (CNS) lesions as those observed in others rodent species. Chemokines, such as RANTES (CCL-5) and MCP-1 (CCL-2), which are important for chemotaxis and activation of inflammatory cells, are expressed during the course of VSV encephalitis. However, the role of CNS resident cells regarding chemokine expression is poorly characterized. Here, we demonstrated that during vesicular stomatitis New Jersey virus (VSNJV) encephalitis in deer mice, chemokines RANTES and MCP-1 are expressed only in the olfactory bulb $(\mathrm{OB})$, where the virus was restricted. This chemokine expression was followed by the influx of inflammatory cells to the OB later in the course of acute disease. Neurons, astrocytes and microglia expressed RANTES, whereas MCP-1 was expressed by neurons and astrocytes. Although astrocytes and microglia responded to VSNJV infection by expressing chemokines, neurons were the predominantly infected cell type. Therefore, infected neurons may have a critical role in initiating an immune response in the OB. The signaling between neurons and other CNS resident cells is most likely the mechanism by which astrocytes and microglia are activated during the course of VSV encephalitis. Our results also indicate that the expression of RANTES and MCP-1 in the OB of deer mice infected with VSNJV might help prevent the spread of VSNJV to other areas of CNS. 


\subsection{INTRODUÇÃO}

O vírus da estomatite vesicular (VEV) é vírus envelopado que possui uma única fita de RNA e que pertence ao gênero Vesiculovirus da família Rhabdoviridae. O VEV é um vírus bem reconhecido, que causa uma encefalite aguda em camundongos quando inoculado pela via intranasal. Inicialmente, o VEV infecta neurônios receptores olfatórios do neuro-epitélio e segue no sentido caudal para bulbo olfatório (BO); e posteriormente se dissemina para regiões mais caudais do sistema nervoso central (SNC) (HUNEYCUTT et al., 1994). O rato-veadeiro (Peromyscus maniculatus), um roedor nativo do Novo Mundo, também é susceptível a infecção pelo vírus da estomatite vesicular sorotipo New Jersey (VEVNJ) (CORNISH et al., 2001). Quando inoculado pela via intranasal, o VEVNJ se dissemina pelo SNC do rato-veadeiro por meio do transporte transneuronal retrógrado e por meio do sistema ventricular (CORNISH et al., 2001). Uma vez que a patogênese da infecção pelo VEVNJ no rato-veadeiro é semelhante àquela descrita para outras espécies de roedores (CORNISH et al., 2001), aquela espécie pode ser utilizada como modelo viral de infecção do SNC.

Em camundongos, o VEV infecta neurônios com uma rápida ativação da micróglia e de astrócitos, o que contribui para o desenvolvimento da encefalite (BI et al., 1995). O recrutamento de células inflamatórias para o SNC pode ser desencadeado por diversas quimiocinas, que podem ser expressadas por células residentes do SNC, incluindo neurônios, micróglia e astrócitos (ASENSIO; CAMPBELL, 1999). As quimiocinas pertencem a um grupo de pequenas proteínas secretadas, as quais são divididas em duas principais subfamílias, baseado no arranjo dos resíduos amino-terminais de cisteína dependendo se os dois primeiros resíduos são separados por um aminoácido (CXC) ou não (CC) (ZLOTNIK; YOSHIE, 2000). Durante a encefalite causada pelo VEV em camundongos, diversas quimiocinas são expressas durante o pico da inflamação aguda, incluindo a quimiocina monocyte chemoattractant protein-1 (MCP-1), também conhecida como C-C motif ligand 2 (CCL-2), e RANTES (regulated on activation, normal T-cell expressed and secreted), também conhecida como CCL-5 (IRELAND; REISS, 2006; STEEL et al., 2014). Estas quimiocinas são expressas em diversas condições inflamatórias e degenerativas do SNC. RANTES e MCP-1 estão envolvidas 
principalmente na ativação e infiltração de monócitos e linfócitos $T$ para 0 neuroparênquima (REISS et al., 2002). Adicionalmente, a quimiocina MCP-1 está envolvida no recrutamento de células natural killer (DESHMANE et al., 2009). A expressão de RANTES no SNC de camundongos infectados pelo herpesvírus simples tipo 1 (HSV-1) é responsável pela adesão e rolamento de leucócitos na microvasculatura, contribuindo assim para o desenvolvimento da encefalite (VILELA et al., 2009). Em condições neurodegenerativas, tais como a encefalomielite autoimune experimental, a qual é um modelo para esclerose múltipla, a expressão das quimiocinas RANTES e MCP-1 está correlacionada com a adesão de leucócitos à microvasculatura cerebral (DOS SANTOS et al., 2005). Embora a expressão destas quimiocinas esteja frequentemente correlacionada com a inflamação e dano ao neuroparênquima, em algumas condições, tanto RANTES como MCP-1 podem exercer um efeito neuroprotetor (MADRIGAL et al., 2009; TRIPATHY et al., 2010).

A infecção pelo VEV em camundongos de laboratório tem sido extensivamente estudada. Entretanto, a resposta imune de ratos-veadeiros frente a infecção pelo VEV ainda não foi investigada. Embora se saiba que as quimiocinas são cruciais para o desenvolvimento da encefalite causada pelo VEV, poucos estudos foram desenvolvidos no intuito de verificar a função das células residentes do SNC no tocante à produção de quimiocinas durante a infecção pelo VEV. Portanto, o objetivo do presente estudo foi avaliar a expressão e a origem celular de RANTES e MCP-1 no SNC durante a infecção aguda pelo VEV em ratos-veadeiros adultos.

\subsection{MATERIAIS E MÉTODOS}

\subsubsection{Ratos-veadeiros e o vírus}

Ratos-veadeiros fêmeas, de seis semanas de idade, provenientes de um estudo prévio foram utilizadas (CORNISH et al., 2001). Todos os procedimentos experimentais foram realizados sob um protocolo aprovado pela University of Georgia's Institutional Animal Care and Use Committee, University of Georgia, 
Athens, USA. Antes da realização dos procedimentos experimentais, todos os animais foram testados para anticorpos neutralizantes anti-VEVNJ como descrito por Cornish et al. (2001).

O VEVNJ cepa Colorado foi fornecido pelo National Veterinary Services Laboratories (NVSL), US Department of Agriculture (NVSL accession No. 95-44625). O vírus foi isolado em 1995 de um equino no Colorado, EUA. O isolado viral foi passado e titulado em microplacas contendo monocamadas de células Vero (CORNISH et al., 2001). A dose infectante utilizada foi de $1 \times 10^{6} \mathrm{TCID}_{50}$ (dose infectante em $50 \%$ do cultivo celular) em $50 \mu \mathrm{L}$ de meio essencial mínimo (MEM).

\subsubsection{Inoculação intranasal}

Trinta e cinco ratos-veadeiros foram anestesiados com quetamina $(100 \mathrm{mg} / \mathrm{Kg})$ e xilazina $(10 \mathrm{mg} / \mathrm{Kg})$ e os mesmos foram inoculados por meio da via intranasal com $1 \times 10^{6}$ TCID $_{50}$ de VEVNJ-Colorado em 50 $\mu \mathrm{L}$ de MEM conforme descrito previamente (CORNISH et al., 2001). Estes animais foram divididos em grupos de 5 camundongos, sendo que cada grupo foi eutanasiado por overdose de $\mathrm{CO}_{2}$ em 1 a 7 dias pós-inoculação (DPI). Adicionalmente, 5 camundongos foram utilizados como controles negativos e os mesmos foram inoculados por via intranasal com MEM sem o vírus. Os camundongos controle foram eutanasiados no 7 DPI. A necropsia foi realizada em todos os camundongos, incluindo os animais controle. O SNC e a cavidade nasal de cada animal foram coletados.

\subsubsection{Histologia e imuno-histoquímica (IHQ)}

Os tecidos coletados foram fixados em formalina tamponada por 24 a $48 \mathrm{~h}$ seguidos de descalcificação em ácido fórmico a $5 \%$ das cavidades nasais. Posteriormente, os tecidos foram processados rotineiramente para histologia e foram embebidos em parafina. Secções de $3 \mu \mathrm{m}$ foram coradas por hematoxilina e eosina (HE) para avaliar as lesões histológicas. Secções coronais de diferentes regiões do 
SNC foram avaliadas, tais como o bulbo olfatório (BO); região septo-striatal; diencéfalo caudal (hipocampo e tálamo); mesencéfalo rostral (hipocampo caudal) e cerebelo rostral com os pedúnculos cerebelares.

A imuno-histoquímica (IHQ) para as quimiocinas RANTES e MCP-1, e para o VEVNJ foi realizada em todas as áreas do SNC descritas anteriormente. Adicionalmente, a IHQ para VEVNJ foi realizada na cavidade nasal dos camundongos.

RANTES e MCP-1 foram detectadas por meio de IHQ como descrito previamente (HICKS et al., 2013), com algumas modificações. Secções de $3 \mu \mathrm{m}$ foram submetidas a recuperação antigênica (RA) com Borg Decloaker (Biocare Medical, Concord, California, USA) por $10 \mathrm{~min}$ em uma panela de pressão (Biocare Medical, Concord, California, USA) a $120^{\circ} \mathrm{C}$. Posteriormente, as secções foram incubadas com Power Block ${ }^{\mathrm{TM}}$ (Biogenex, Fremont, California, USA) por 7 minutos na temperatura ambiente seguida de incubação com uma solução de peróxido de hidrogênio a 3\% na temperatura ambiente por $10 \mathrm{~min}$. Os anticorpos primários: goat polyclonal anti-mouse CCL5 (AF478; R\&D Systems, Minneapolis, Minnesota, USA) e goat polyclonal anti-mouse CCL2 (AF-479-NA; R\&D Systems, Minneapolis, Minnesota, USA) foram incubados por $1 \mathrm{~h}$ na temperatura ambiente nas diluições de 1:200 e 1:800 respectivamente. Como controle negativo, os anticorpos primários foram substituídos por um Goat Super Sensitive negative control (Biogenex, Fremont, California, USA). Após a incubação com os anticorpos primários, as lâminas foram incubadas com anticorpo secundário rabbit biotinylated anti-goat (Vector Laboratories, Burlingame, California, USA) diluído a 1:200 por 20 min seguido de incubação com streptavidina conjugada a peroxidase (Biocare Medical, Concord, California, USA). A ligação entre antígenos e anticorpos foi visualizada utilizado-se o substrato DAB (3,3'-diaminobenzidina) (Vector Laboratories, Burlingame, California, USA), seguido de leve contracoloração com hematoxilina. Secções de baço e tecido linfoide sem alterações histológicas de ratos-veadeiros naïve foram utilizados como controles positivos.

Para a detecção dos antígenos de VEVNJ, a IHQ foi realizada nos tecidos fixados em formalina e embebidos em parafina utilizando-se o método da fosfatase alcalina conjugada a streptavidina-biotina conforme descrito previamente (CORNISH et al., 2001). Resumidamente, secções de $3 \mu \mathrm{m}$ foram submetidas a RA com tampão citrato a 0,01M ( $\mathrm{pH} \mathrm{6,0)}$ por $10 \mathrm{~min}$ em panela de pressão (Biocare Medical, 
Concord, California, USA) t $120^{\circ} \mathrm{C}$. As secções foram incubadas com anticorpo primário anti-VEVNJ proveniente de fluido ascítico hiperimune de camundongo (Dr. R. B. Tesh, Department of Pathology, University of Texas Medical Branch, Galveston, TX) em uma diluição de 1:4000 em temperatura ambiente por $1 \mathrm{~h}$. Como controle negativo, foi utilizado um Mouse Super Sensitive negative control (Biogenex, Fremont, California, USA). Posteriormente, as secções foram incubadas com um link universal biotinilado feito em cabras (Biocare Medical, Concord, California, USA) seguido de incubação com fosfatase alcalina conjugada a streptavidina (Biocare Medical, Concord, California, USA). A reação foi revelada utilizando-se o Vulcan Fast Red Chromogen (Biogenex, Fremont, California, USA) seguido de leve contracoloração com hematoxilina. Secções do SNC de ratosveadeiros previamente infectados pelo VEVNJ foram utilizados como controle positivo.

\subsubsection{Imunofluorescência}

Secções de SNC embebidas em parafina foram cortadas a $3 \mu \mathrm{m}$ e preparadas para imunofluorescência. Primeiramente, as secções de SNC foram submetidas a imunofluorescência com os anticorpos primários individualmente. Resumidamente, as secções foram submetidas a RA com Borg Decloaker (Biocare Medical, Concord, California, USA), semelhantemente ao descrito anteriormente para IHQ convencional, seguido de bloqueio com soro equino a 2,5\% por $30 \mathrm{~min}$ em temperatura ambiente. Posteriormente, as secções foram incubadas por $2 \mathrm{~h}$ a $37^{\circ} \mathrm{C}$ com os seguintes anticorpos primários: anti-CCL5 (goat, 1:20, R\&D Systems, Minneapolis, Minnesota, USA); anti-CCL2 (goat, 1:20, R\&D Systems, Minneapolis, Minnesota, USA); anti-proteína glial fibrilar ácida (GFAP) (rabbit, 1:100, Dako, Carpinteria, California, USA); anti-lba-1 (rabbit, 1:500, Wako, Richmond, Virginia); e anti-NeuN (guinea pig, 1:200, Millipore, Temecula, California, USA). Após a incubação com os anticorpos primários, as secções foram incubadas por $1 \mathrm{~h}$ a temperatura ambiente, em câmara escura, com os seguintes anticorpos secundários apropriados: Alexa 488 anti-goat (donkey, 1:100, Jackson Immunoresearch, West Grove, Pennsylvania, USA); Alexa 594 anti-rabbit (chicken, 1:400, Molecular Probes, 
Eugene, Oregon, USA); e Alexa 594 anti-guinea pig (donkey, 1:400, Jackson Immunoresearch, West Grove, Pennsylvania, USA). As lâminas foram lavadas em PBS, pH 7,2 por três vezes e as mesmas foram montadas com meio Prolong ${ }^{\circledR}$ gold antifade mountant com DAPI (Molecular Probes, Eugene, Oregon, USA). Para duplaimunofluorescência, cada anticorpo primário, anti-CCL-5 ou anti-CCL-2 foi incubado juntamente com os diferentes marcadores de células residentes do SNC (GFAP, Iba1 e NeuN), seguido de uma incubação com uma mistura apropriada de anticorpos secundários descritos anteriormente. Adicionalmente, a imunofluorescência foi realizada para detectar antígenos de VEVNJ em amostras de SNC e cavidade nasal dos camundongos infectados. Para tal, as secções foram submetidas a RA conforme descrito anteriormente para IHQ convencional, seguido de bloqueio com soro fetal caprino a $2 \%$ por $30 \mathrm{~min}$ em temperatura ambiente. As secções foram incubadas com o anticorpo primário anti-VEVNJ proveniente de fluido ascítico hiperimune de camundongo (Dr. R. B. Tesh) em uma diluição de $1: 800$ por $2 \mathrm{~h}$ a $37^{\circ} \mathrm{C}$, seguido de incubação por $1 \mathrm{~h}$ em câmara escura em temperatura ambiente com o anticorpo secundário Alexa 488 anti-mouse (goat, 1:200, Jackson Immunoresearch, West Grove, Pennsylvania, USA). As amostras de SNC também foram submetidas a dupla-imunofluorescência com anticorpo primário anti-VEVNJ associado a diferentes marcadores celulares (GFAP, lba-1 e NeuN) utilizando-se uma mistura de anticorpos primários seguido de uma mistura apropriada de anticorpos secundários. A dupla marcação das quimiocinas e marcadores celulares foram avaliadas utilizando-se um microscópio confocal Zeiss LSM 710. As imagens da dupla-imunofluorescência para VEVNJ com os diferentes marcadores celulares foram obtidas utilizando-se diferentes filtros em um microscópio de fluorescência (Olympus BX41), sendo que as imagens de um mesmo campo foram sobrepostas utilizando-se o software ImageJ (National Institute of Health, USA).

\subsubsection{Análise morfométrica}

Uma análise quantitativa foi realizada para avaliar a marcação para RANTES e MCP-1 no SNC de três animais de cada grupo. Para tal, o BO foi dividido em dois regiões principais. A primeira incluiu as camadas do nervo olfatório e glomerular (Região 1) e a segunda região compreendeu as camadas plexiforme externa, mitral, 
plexiforme interna e granular (Região 2). Dez campos de 400X não sobrepostos foram selecionados em cada região principal. Primeiramente, avaliou-se o BO e os campos foram selecionados baseando-se no número de células positivas. Os campos com maior número de células foram selecionados primeiramente, seguidos pelos campos com menor número de células positivas e campos sem nenhuma marcação na IHQ. Estes últimos foram selecionados randomicamente. A média da área por um campo de 400X para as Regiões 1 e 2 foi de 135,000 $\mu^{2}$ e 148,000 $\mu^{2}$ respectivamente. O número total de células positivas em cada campo e o tamanho da área analisada foram mensurados utilizando-se o software ImageJ (National Institute of Health, USA). As células foram consideradas positivas quando havia total marcação do citoplasma e quando o núcleo desta célula era facilmente reconhecível. Em cada secção de outras áreas avaliadas do SNC (septo striatal; diencéfalo caudal; mesencéfalo rostral; e cerebelo rostral), a seleção dos campos, bem como a contagem foi realizada semelhantemente ao descrito anteriormente com uma área média de $148,000 \mu \mathrm{m}^{2}$ por campo de 400X.

\subsubsection{Análise estatística}

Os dados foram primeiramente analisados para a distribuição normal utilizando-se o teste de Shapiro-Wilk. A homocedasticidade foi testada utilizando-se o teste de Levene. Os dados que não mostraram distribuição normal foram testados por meio do teste não paramétrico Kruskal-Wallis seguido do teste de LSD para uma múltipla comparação das médias ranqueadas. O nível de significância considerado foi de $p<0.05$. Todos os testes foram realizados utilizando-se o software SPSS 20.0 (IBM). 


\subsection{RESULTADOS}

\subsubsection{Expressão de RANTES e MCP-1 no SNC de ratos-veadeiros infectados com VEVNJ}

O SNC foi divido em diferentes regiões para se estudar a distribuição da expressão de RANTES e MCP-1. As regiões analisadas incluíram o BO; septo striatal; diencéfalo caudal (hipocampo e tálamo); mesencéfalo rostral (hipocampo caudal); e cerebelo rostral com os pedúnculos cerebelares. A marcação para RANTES e MCP-1 foi detectada somente no BO de ratos-veadeiros adultos infectados pelo VEVNJ. As células foram consideradas positivas para RANTES e MCP-1 quando havia marcação intracitoplasmática intensa e homogênea quando comparada aquelas observadas no grupo controle (Figura 1). O VEVNJ quando inoculado pela via intranasal em camundongos e ratos-veadeiros infecta neurônios receptores olfatórios da mucosa nasal (PLAKHOV et al., 1995; CORNISH et al., 2001). Os axônios destes neurônios olfatórios penetram na placa cribiforme e entram no BO (MORI et al., 2005), realizando sinapses no nível da camada glomerular com tufted cells cujos corpos celulares estão localizados na camada mitral (IMAI, 2014). Células mitrais e tufted cells realizam sinapse com as células granulares as quais compõem a maior população de interneurônios no BO localizados na camada granular (IMAI, 2014). Portanto, para se estudar a distribuição da expressão de RANTES e MCP-1, o BO foi dividido em duas regiões principais. A primeira região (Região 1 ) incluiu as camadas do nervo olfatório e glomerular e a segunda região (Região 2) compreendeu a camada plexiforme externa até a camada mais interna do BO (camada granular).

Em ambas as regiões analisadas, o número de células expressando RANTES ou MCP-1 variou significativamente entre os diferentes dias analisados $(p<0.05)$. RANTES foi primeiramente detectada em um alto número de células na Região 1 no $4 \mathrm{DPI}$, seguido por uma queda nesta região no $7 \mathrm{DPI}$ (Gráfico $1 \mathrm{~A}$ ). Semelhantemente, na Região 2, RANTES foi primeiramente detectada no 4 DPI (Gráfico 1B). Entretanto, o número de células positivas para RANTES nesta região aumento significativamente do 5 para o 6 DPI. Em ambas as regiões, nenhuma 
diferença foi encontrada na expressão de RANTES entre os animais controle e os animais infectados pelo VEVNJ no 1, 2, e 3 DPI. No tocante a expressão de MCP-1, um número significativo de células positivas foi primeiramente detectado no $4 \mathrm{DPI}$, com uma queda no $5 \mathrm{DPI}$. Esta diminuição chegou a um número de células positivas que não diferiu estatisticamente do número de células positivas observadas no $1 \mathrm{DPI}$ (Gráfico $1 \mathrm{C}$ ). Na região 2, MCP-1 foi também detectada primeiramente em um alto número de células no 4 DPI, com um aumento do 5 para o 6 DPI (Gráfico 1D). 
Figura 1 - Expressão de RANTES (CCL-5) e MCP-1 (CCL-2) por imuno-histoquímica no bulbo olfatório de ratos-veadeiros infectados pelo VEVNJ

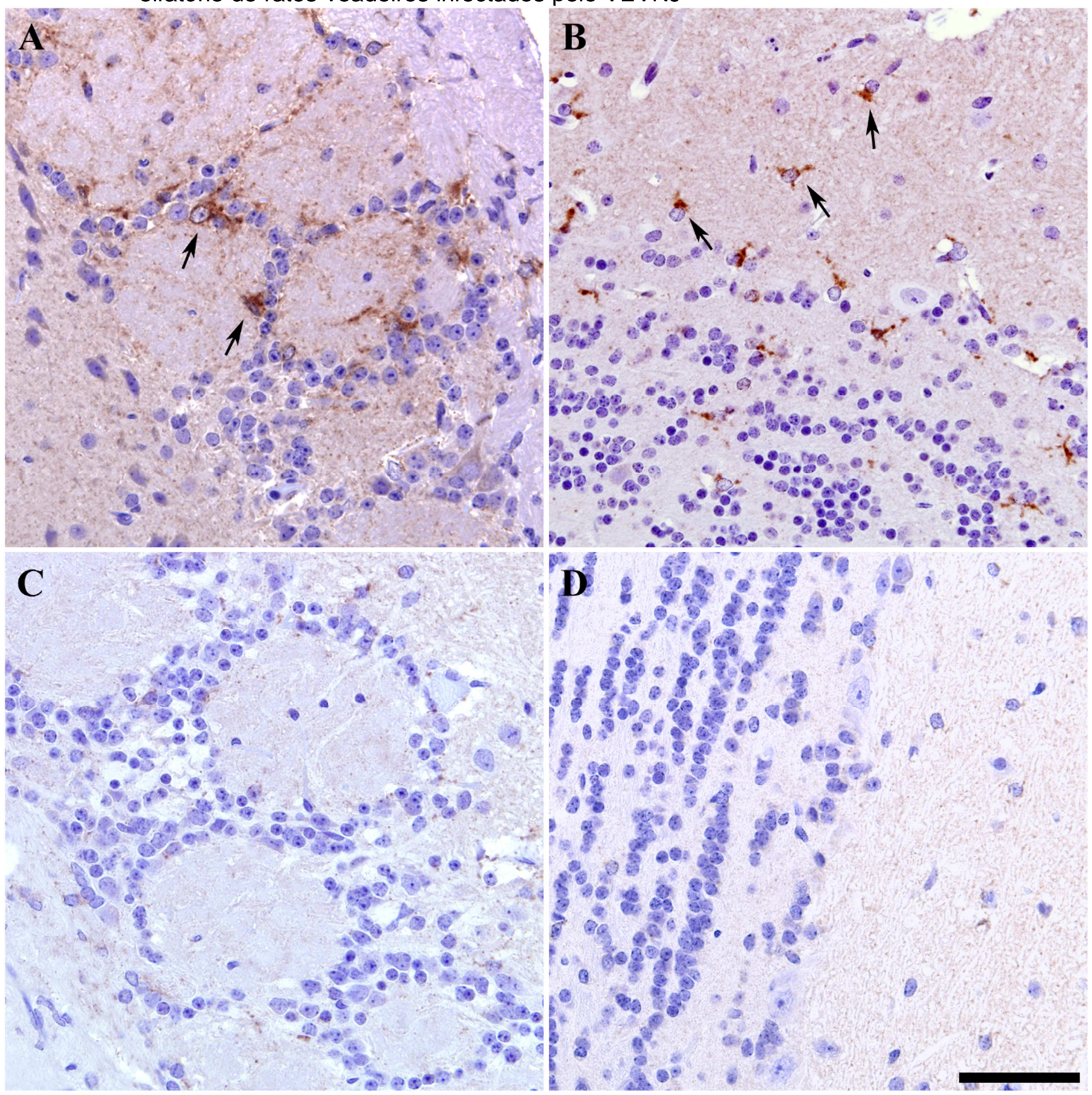

Fonte: (MESQUITA, L. P., 2016)

Legenda: Nas camadas do nervo olfatório e glomerular, uma intensa marcação intracitoplasmática para CCL-5 (setas) foi observada (A). Uma intensa marcação intracitoplasmática para CCL2 (setas) foi observada em células localizadas na camada plexiforme externa até a camada granular (B). Nos animais controle, células com marcação proeminente para CCL-5 (C) e CCL-2 (D) não foram observadas. Células positivas individuais foram contadas para análise morfométrica. IHQ. Barras, $50 \mu \mathrm{m}(\mathrm{A}-\mathrm{D})$. 
Gráfico 1 - Número de células positivas para RANTES (CCL-5) e MCP-1 (CCL-2) por imunohistoquímica no bulbo olfatório de ratos-veadeiros infectados pelo VEVNJ em diferentes dias pós inoculação (DPI)

A
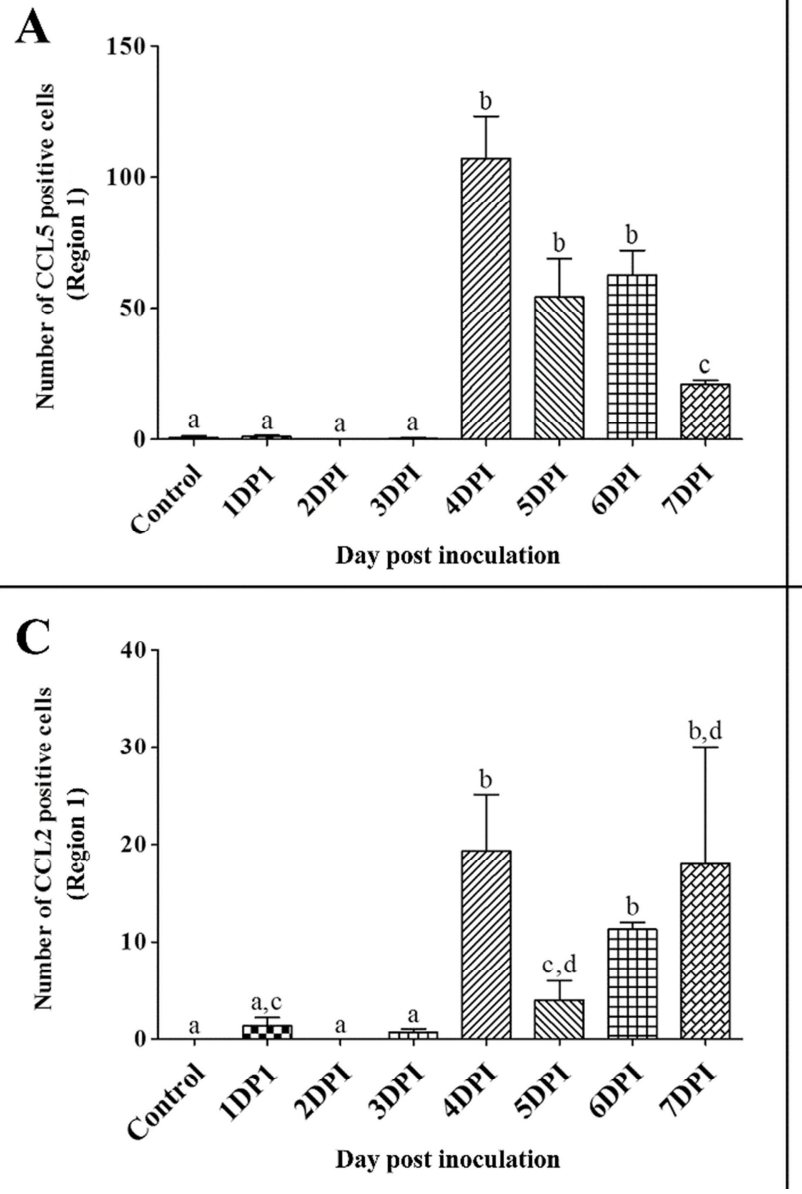

B

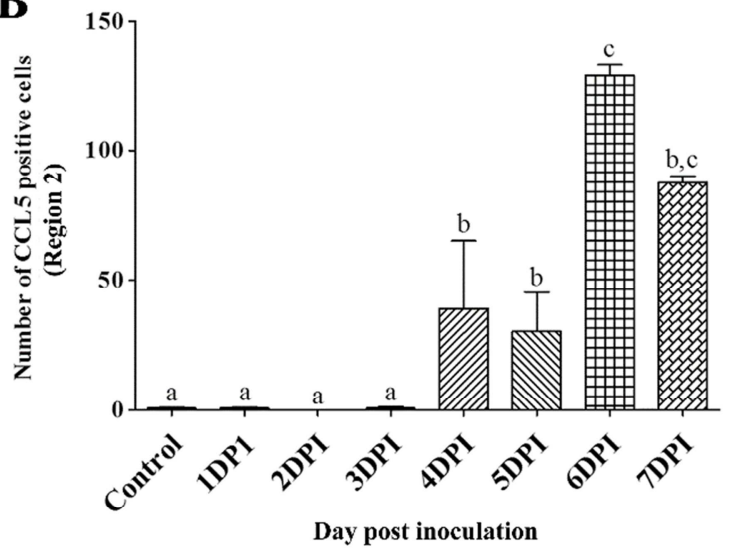

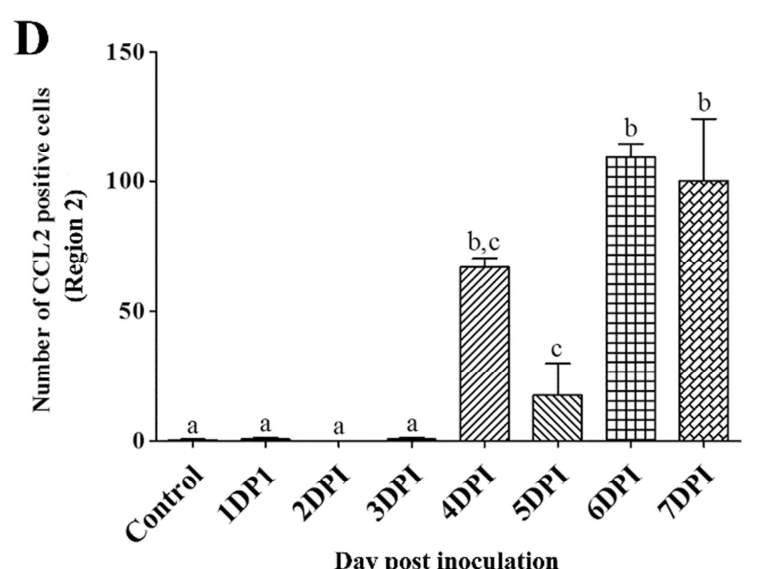

Fonte: (MESQUITA, L. P., 2016)

Legenda: Expressão de CCL-5 nas camadas do nervo olfatório e glomerular (Região 1) (A); e camadas plexiforme externa, células mitrais, plexiforme interna e granular (Região 2) (B). Expressão de CCL-2 nas camadas do nervo olfatório e glomerular (Região 1) (C); e camadas plexiforme externa, células mitrais, plexiforme interna e granular (Região 2) (D). As barras representam a média \pm SEM. A significância foi determinada utilizando-se o teste de Kruskal-Wallis $(p<0.05)$ seguido do teste LSD. As diferentes letras acima das barras de erro indicam uma diferença significativa entre os diferentes DPI (média ranqueada, LSD. $p$ $<0.05)$.

\subsubsection{Expressão de RANTES e MCP-1 em células residentes do SNC de ratos-veadeiros infectados com VEVNJ}

Diversas quimiocinas, tais como RANTES e MCP-1 são expressas no SNC durante a encefalite causada por VEV em camundongos (IRELAND; REISS, 2006). Entretanto, pouco se sabe sobre a origem celular destas quimiocinas no SNC. Portanto, no presente estudo, a origem celular destas quimiocinas foi avaliada por 
meio de dupla marcação com diferentes marcadores celulares. O marcador microglial utilizado no presente estudo lba-1 poderia também marcar monócitos derivados do sangue que durante um evento de neuro-inflamação podem adentrar e se tornarem ativadas no SNC. Entretanto, no neuroparênquima, a grande maioria das células positivas para Iba-1 possuíam morfologia consistente com a micróglia ramificada (dados não mostrados) (GLENN et al., 1992). Portanto, no presente estudo, as células positivas para lba-1 serão referidas como micróglia.

RANTES estava co-localizada com o marcador astrocítico GFAP (Figura 2A a C) e com o marcador microglial Iba-1 (Figura 2D a F). Adicionalmente, RANTES foi visualizada no citoplasma de células cujos núcleos foram marcados pelo marcador neuronal NeuN (Figura 2G a I). Estes resultados sugerem que os astrócitos, neurônios e micróglia no BO expressam RANTES durante a encefalite causada por VEVNJ em ratos-veadeiros. Por outro lado, MCP-1 estava co-localizada com GFAP (Figura $3 \mathrm{~A}$ a $\mathrm{C}$ ) e também foi observada no citoplasma de células cujos núcleos eram positivos para o marcador neuronal NeuN (Figura 3D a F). Entretanto, MCP-1 não foi co-localizada com o marcador microglial lba-1 (Figura 3G a I), sugerindo que a quimiocina MCP-1 é principalmente expressa em neurônios e astrócitos do BO, mas não em micróglia durante a encefalite causada pelo VEVNJ. 
Figura 2 - Astrócitos, neurônios e micróglia no bulbo olfatório expressam RANTES (CCL-5) durante a encefalite causada por VEVNJ em ratos-veadeiros

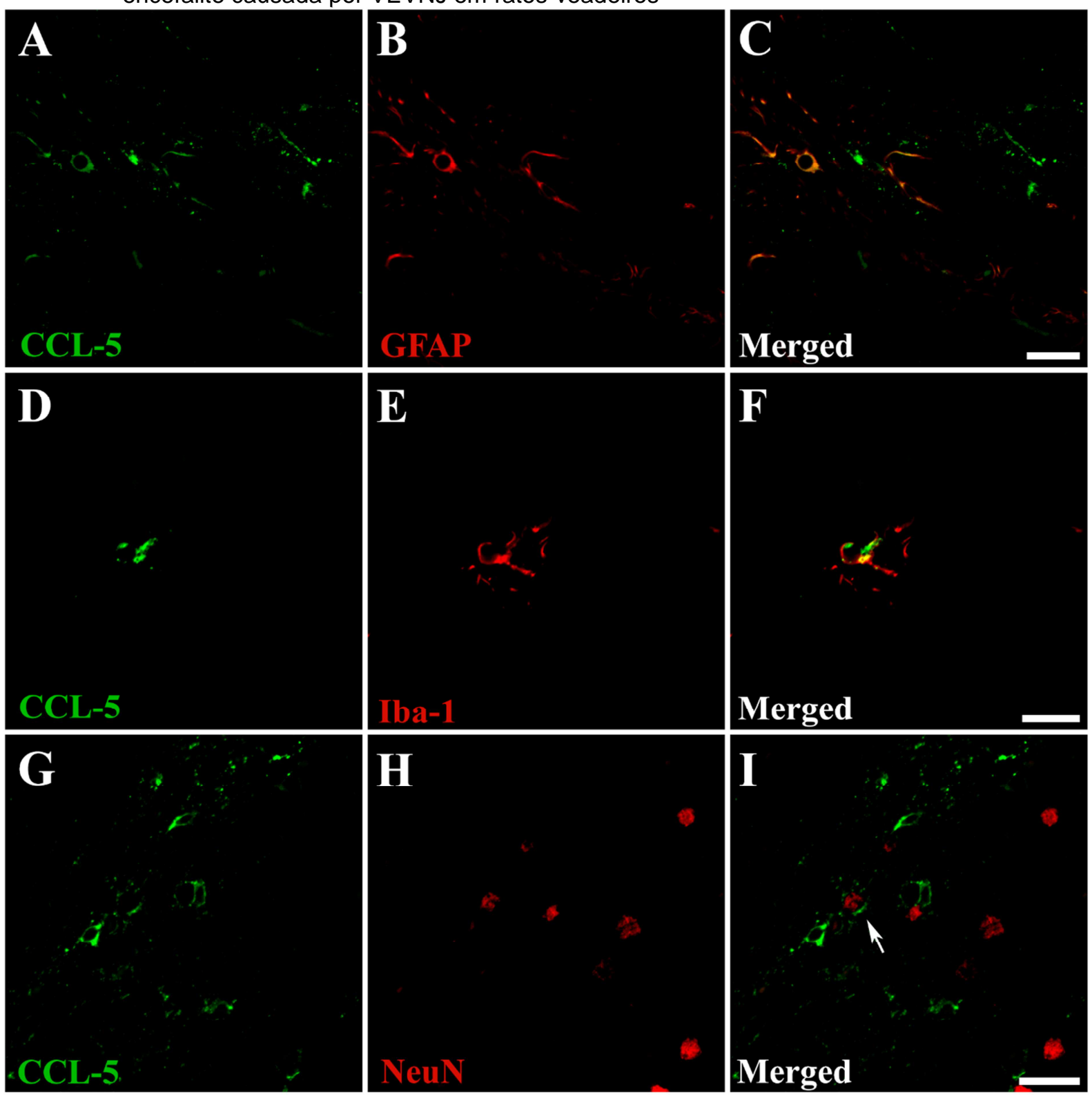

Fonte: (MESQUITA, L. P., 2016)

Legenda: CCL-5 foi detectada em células GFAP+ (A-C), em células Iba-1+ (D-F) e estava localizada na região perinuclear (seta) de células $\mathrm{NeuN}+(\mathrm{G}-\mathrm{I})$. Dupla-imunofluorescência. Barras, 25 $\mu \mathrm{m}(\mathrm{A}-\mathrm{I})$. 
Figura 3 - Astrócitos e neurônios no bulbo olfatório, exceto micróglia, expressam MCP-1 (CCL-2) durante a encefalite causada por VEVNJ em ratos-veadeiros

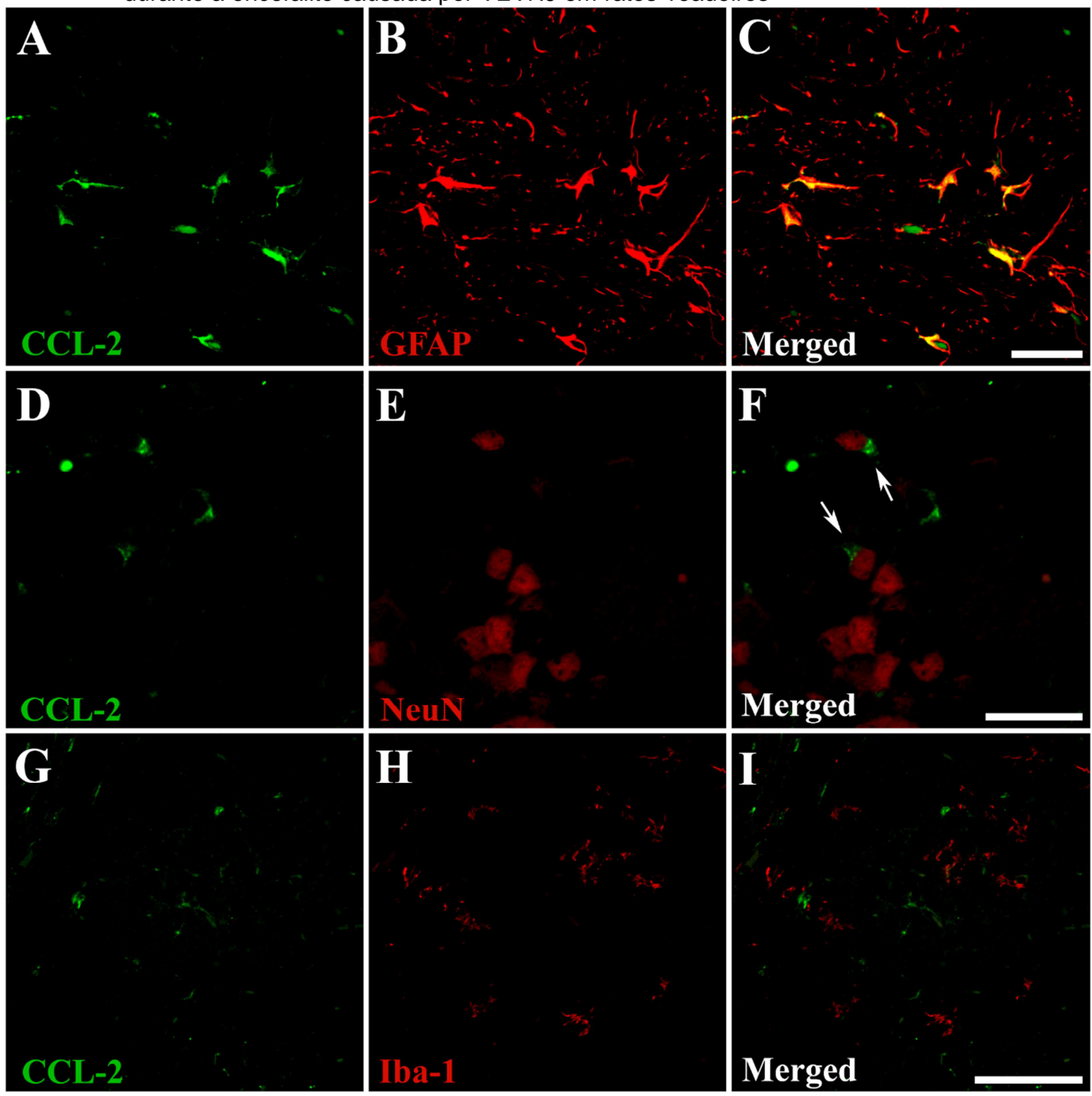

Fonte: (MESQUITA, L. P., 2016)

Legenda: CCL-2 foi detectada em células GFAP+ $(A-C)$, bem como na região perinuclear (setas) de células $\mathrm{NeuN}+(\mathrm{D}-\mathrm{F})$. Entretanto, CCL-2 não estava co-localizada em células Iba-1+ (G-I). Dupla-imunofluorescência. Barras, $25 \mu \mathrm{m}(\mathrm{A}-\mathrm{F})$ e $100 \mu \mathrm{m}$ (G-I).

\subsubsection{Distribuição de VEVNJ Colorado no SNC de ratos-veadeiros infectados}

No $1 \mathrm{DPI}$, havia uma marcação leve, multifocal e intracitoplasmática para os antígenos de VEVNJ no epitélio olfatório e raras células epiteliais das glândulas de Bowman (Figura 4A). No 3 até o 6 DPI, haviam áreas localmente extensas nas quais 
grande quantidade de antígenos virais foram visualizadas ao longo do epitélio olfatório, incluindo as glândulas de Bowman (Figura 4B). No 7 DPI, a marcação para o VEVNJ tornou-se menos proeminente, com somente a marcação multifocal leve a moderada no epitélio olfatório.

No BO, antígenos de VEVNJ foram inicialmente detectados no 2 DPI. Nos 3 e $4 \mathrm{DPI}$, antígenos de VEVN foram principalmente visualizados nas camadas do nervo olfatório, glomerular e plexiforme externa (Figura 4C), com ocasionais marcações da camada de células mitrais e discreta extensão destas marcações para as camadas plexiforme interna e granular no 4 DPI (Figura 4D). No 7 DPI, antígenos de VEVNJ ainda podiam ser detectados em todas as camadas do $\mathrm{BO}$. Antígenos virais não foram observados no SNC caudalmente ao BO.

A dupla-imunofluorescência para o VEVNJ com diferentes marcadores celulares revelou que o vírus estava predominantemente localizado no citoplasma de neurônios (células $\mathrm{NeuN+}$ ) (Figura 5A a C) e seus processos. Raramente, o VEVNJ estava co-localizado com o marcador astrocítico GFAP (Figura 5D a F). Os antígenos de VEVNJ não estavam co-localizados com o marcador microglial lba-1 (Figura 6G a I). 
Figura 4 - Distribuição de VEVNJ no SNC de ratos-veadeiros infectados
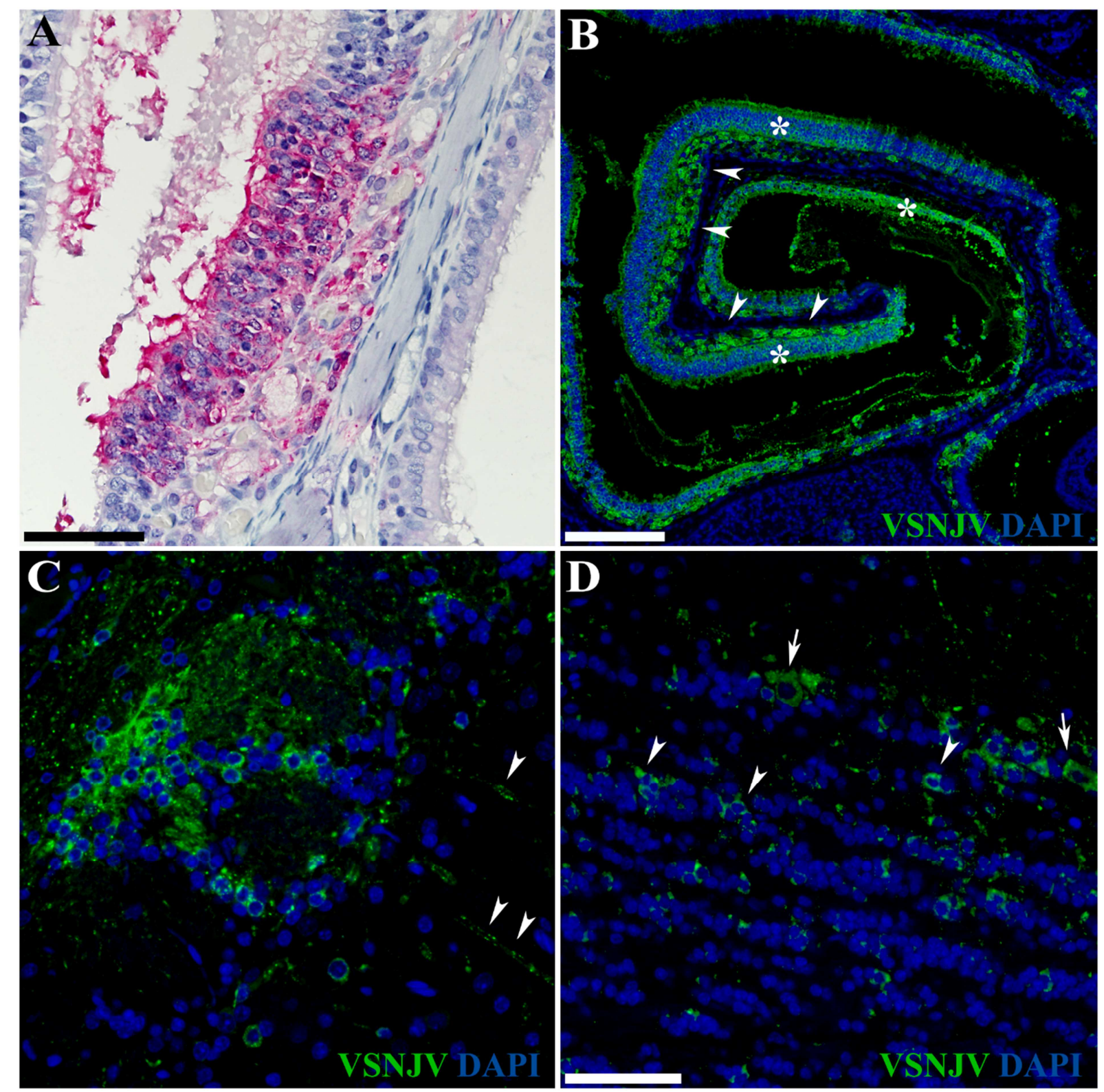

Fonte: (MESQUITA, L. P., 2016)

Legenda: No 1 DPI, antígenos de VEVNJ foram observados no epitélio olfatório e glândulas de Bowman subjacentes nas conchas nasais (A), IHQ. No 4 DPI, a marcação para VEVNJ tornou-se disseminada no epitélio olfatório (asteriscos) e glândulas de Bowman subjacentes (cabeças de setas) (B), imunofluorescência. No bulbo olfatório, no 4 DPI, antígenos de VEVNJ estavam presentes nas camadas do nervo olfatório e glomerular com uma leve extensão para a camada plexiforme externa, onde os antígenos virais também foram detectados nos processos neuronais (cabeças das setas) (C), imunofluorescência. Adicionalmente, no 4 DPI, VEVNJ estava presente nas camadas de células mitrais e granular, onde os antígenos virais foram detectados nas células mitrais (setas) e células granulares (cabeças das setas) (D), imunofluorescência. Barras, $50 \mu \mathrm{m}(A), 400 \mu \mathrm{m}(B) \mathrm{e}$ $40 \mu \mathrm{m}(\mathrm{C}-\mathrm{D})$. 
Figura 5 - O VEVNJ infecta predominantemente neurônios e raros astrócitos no SNC de ratosveadeiros infectados

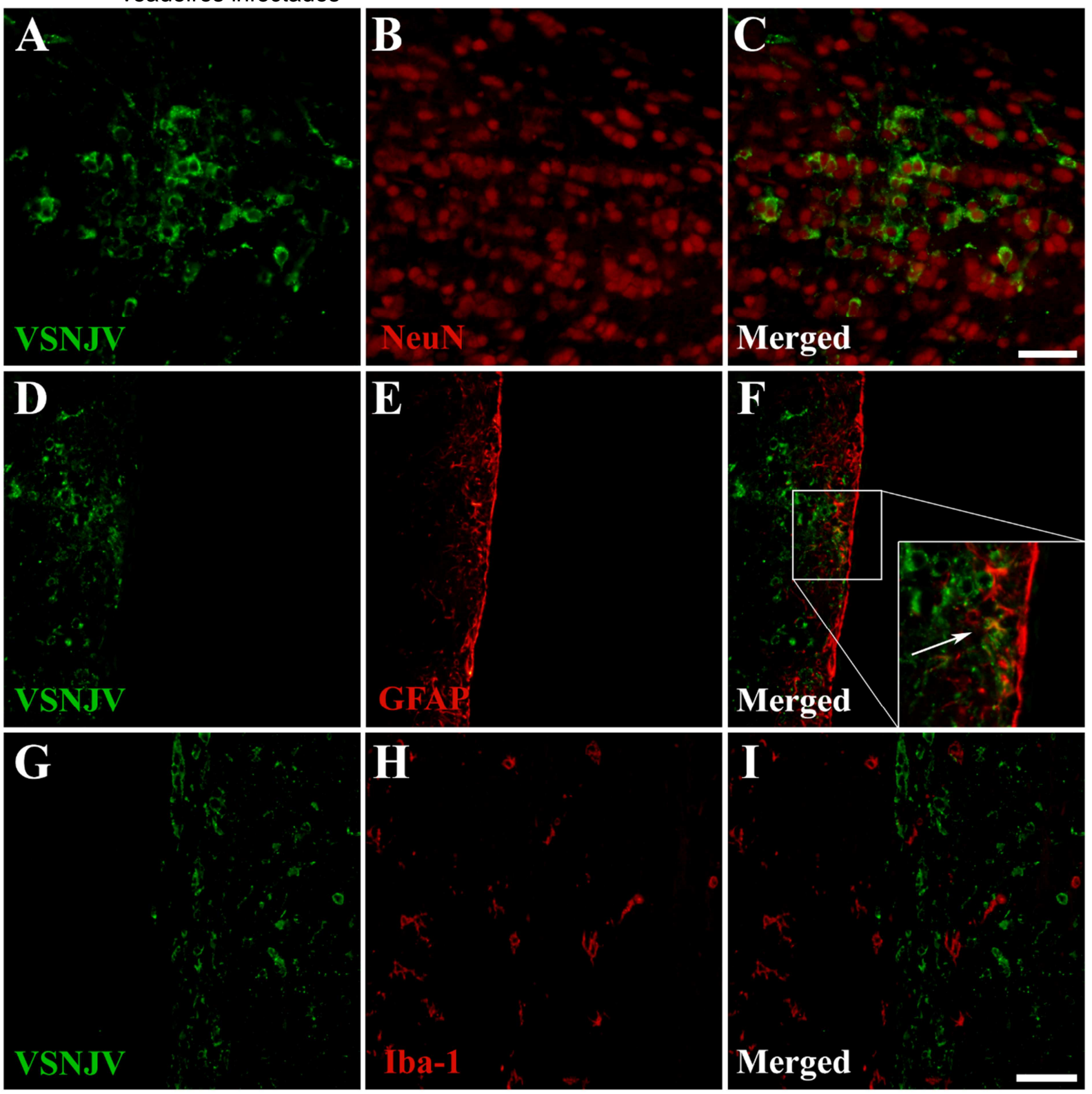

Fonte: (MESQUITA, L. P., 2016)

Legenda: A grande maioria dos antígenos de VEVNJ foram observados dentro do citoplasma de células NeuN+ (A-C). Antígenos de VEVNJ raramente foram detectados em células GFAP+ (inset, seta) (D-F) e os mesmos não apresentaram co-localização com células Iba-1+ (G-I). Dupla-imunofluorescência. Barras, $20 \mu \mathrm{m}(\mathrm{A}-\mathrm{C})$ e $75 \mu \mathrm{m}$ (D-I). 


\subsubsection{Lesões microscópicas}

As lesões nas conchas nasais de ratos-veadeiros adultos infectados pelo VEVNJ tornaram-se mais proeminentes a partir do $3 \mathrm{DPI}$. Neste, havia vacuolização multifocal do epitélio olfatório com um moderado número de células epiteliais necróticas. O lúmen estava preenchido por uma discreta a moderada quantidade de debris celulares associado a poucos neutrófilos degenerados ou viáveis. A lâmina própria estava infiltrada por uma discreta quantidade de macrófagos, plasmócitos e linfócitos. Raramente, havia no lúmen das glândulas de Bowman um baixo número de células necróticas. A necrose do epitélio olfatório progrediu até o $6 \mathrm{DPI}$, no qual havia áreas localmente extensas de erosão e ulceração do epitélio com grande quantidade de debris celulares e um alto número de neutrófilos preenchendo o lúmen das conchas nasais. No $7 \mathrm{DPI}$, havia uma discreta a moderada quantidade de debris celulares preenchendo o lúmen, assim como áreas multifocais de erosão. Entretanto, haviam áreas multifocais nas quais a lâmina basal estava recoberta por única camada de células epiteliais achatadas (epitélio em regeneração).

As lesões no SNC somente foram detectadas no BO. Todas as outras áreas avaliadas, tais como a região septo-striatal; diencéfalo caudal (hipocampo e tálamo); mesencéfalo rostral (hipocampo caudal) e cerebelo rostral com os pedúnculos cerebelares, lesões histológicas não foram observadas. No $\mathrm{BO}$, as lesões foram detectadas inicialmente no $4 \mathrm{DPI}$. Na camada glomerular, os espaços perivasculares e pericelulares estavam discretamente aumentados (edema). Nesta região havia um discreto infiltrado inflamatório composto predominantemente por neutrófilos nos espaços perivasculares. No $6 \mathrm{DPI}$, o edema estava mais proeminente e os espaços perivasculares estavam multifocalmente preenchidos por uma camada de macrófagos e linfócitos (manguito perivascular), os quais também estavam presentes nas leptomeninges. No $7 \mathrm{DPI}$, a encefalite tornou-se mais severa com um moderado número de macrófagos, linfócitos e raros neutrófilos nas leptomeninges e manguitos perivasculares no neuroparênquima estendendo-se desde a camada glomerular até a granular compostos por 1 a 3 camadas de macrófagos e linfócitos. Nos animais controle, lesões histológicas não foram observadas. 


\subsection{DISCUSSÃO}

As células residentes do SNC dispõem de diversos mecanismos da reposta imune inata os quais são importantes para se debelar infecções causadas por vírus neurotrópicos (NAIR; DIAMOND, 2015). O VEV é um rhabdovirus que em camundongos de laboratório e ratos-veadeiros apresenta um alto neurotropismo cursando com encefalite severa (HUNEYCUTT et al., 1993; CORNISH et al., 2001) com ativação de células gliais resultando em astrocitose e microgliose ( $\mathrm{Bl}$ et al., 1995; CHRISTIAN et al., 1996; CORNISH et al., 2001). Todavia, a resposta imune inata na infecção pelo VEV ainda não foi investigada em ratos-veadeiros. Durante a encefalite causada pelo VEV em camundongos de laboratório, diversas quimiocinas, incluindo RANTES e MCP-1 são expressas no SNC (REISS et al., 2002; STEEL et al., 2014). Entretanto, a origem celular destas quimiocinas durante a infecção causada pelo VEV, assim como a correlação entre a distribuição viral e a expressão destas quimiocinas são pouco caracterizadas. No presente estudo, a inoculação intranasal de VEVNJ-Colorado em ratos-veadeiros adultos induziu a expressão de RANTES e MCP-1 no BO. Em outras áreas do SNC, além do $B O$, não se observaram marcações para estas quimiocinas. No BO, RANTES foi expressa em todas as células residentes do SNC avaliadas, incluindo astrócitos, micróglia e neurônios, ao passo que MCP-1 não foi expressa pela micróglia. Inúmeros estudos demonstraram que vírus neurotrópicos podem induzir uma importante resposta de quimiocinas em células residentes do SNC (HOSKING; LANE, 2010). Células de origem neuronal, quando infectadas in vitro com vírus da raiva (RABV), o qual é intimamente relacionado ao VEV, apresentaram uma expressão robusta de RANTES na ausência de células gliais, demonstrando que os neurônios por si só podem responder a infecção causada por vírus de dsRNA (PRÉHAUD et al., 2005). A micróglia também pode reconhecer e responder à infecção pelo RABV e pelo herpesvírus simples tipo 1 resultando na expressão de quimiocinas, tais como a RANTES (LOKENSGARD et al., 2001; NAKAMICHI et al., 2005). Semelhantemente, no presente estudo, os neurônios e a micróglia expressaram RANTES durante a encefalite causada pelo VEVNJ em ratos-veadeiros. Entretanto, esses resultados diferem daqueles obtidos em camundongos infectados pelo RABV, os quais expressaram RANTES em células gliais, mas não em neurônios (HICKS et al., 
2013). Durante a infecção in vitro pelo vírus da encefalite japonesa, um vírus RNA, RANTES foi induzida em cultivo celular de micróglia e astrócitos, e culturas mistas de neurônios/glia, mas não em neurônios cultivados na ausência de células da glia (CHEN et al., 2004). Além de neurônios e micróglia, RANTES foi expressa por astrócitos nos ratos-veadeiros infectados pelo VEVNJ no presente estudo. Semelhantemente, em outras infecções virais que afetam o SNC tais como o HIV e o vírus da encefalomielite murina de Theiler, RANTES foi expressa em astrócitos, o que pode contribuir ou não para o desenvolvimento da inflamação no SNC (CARPENTIER et al., 2008; LIU et al., 2014). No presente estudo, ao contrário de RANTES, MCP-1 não foi observada na micróglia. Estes resultados são semelhantes àqueles observados in cultivo celulares de micróglia infectado pelo RABV, nos quais se observou a expressão de RANTES, mas não de MCP-1 (ZHAO et al., 2013). Entretanto, no presente estudo, uma grande quantidade de neurônios e astrócitos expressaram MCP-1. Semelhantemente, MCP-1 foi significativamente expressa em neurônios durante a infecção pelo RABV (HICKS et al., 2013) e em astrócitos na infecção pelo HIV (KHIATI et al., 2010). O tipo predominante da célula residente do SNC que expressa MCP-1 pode variar de acordo com o tipo de vírus (TERRY et al., 2012). Os neurônios são importantes produtores de MCP-1 na infecção pelo vírus West Nile (GETTS et al., 2008), ao passo que na infecção pelo HIV, os astrócitos são os principais produtores de MCP-1 (PERSIDSKY et al., 1999).

No presente estudo, o VEVNJ foi predominantemente observado no citoplasma de neurônios do BO de ratos-veadeiros infectados. Raramente, os antígenos de VEVNJ foram visualizados em astrócitos e não foram encontradas marcações para o vírus na micróglia. Os antígenos de VEVNJ que não foram observados em co-localização com os marcadores utilizados no presente estudo, muito provavelmente se encontravam no interior de dendritos e em menor quantidade em axônios, uma vez que a maioria das sinapses no BO são realizadas por conexões dendro-dendríticas (MORI et al., 1999). As células gliais tais como os astrócitos e micróglia, podem ser infectadas pelo VEV, porém a maioria das células infectadas são neurônios (NAIR et al., 2014). Os resultados do presente estudo são similares àquele em que se verificou que os neurônios eram o alvo primário do VEV, sendo que o vírus não foi detectado em células gliais, tais como os astrócitos (FENSTERL et al., 2012). Diferentemente, outro estudo demonstrou a co-localização de antígenos de VEVNJ com marcadores astrocítico e microgliais, sugerindo que a 
infecção destas células gliais podem exercer um papel importante no desenvolvimento da encefalite (CHAUHAN et al., 2010). Entretanto, uma comparação entre os estudos no tocante ao tropismo celular viral é difícil em decorrência de diferentes sorotipos utilizados, dose infectante e idade do animal no momento da inoculação. Importantemente, embora os astrócitos no BO não estavam significativamente infectados pelo vírus, os mesmos expressaram tanto RANTES como MCP-1, ao passo que a micróglia expressou somente MCP-1. Nos neurônios, ao contrário das células gliais, havia grande quantidade de antígenos de VEVNJ. Portanto, a comunicação entre neurônios e células gliais muito provavelmente é o mecanismo pelo qual as células gliais tais como astrócitos e micróglia são ativados durante a encefalite por VEVNJ em ratos-veadeiros. A micróglia bem como os astrócitos podem responder rapidamente à lesão neuronal expressando maiores quantidades de moléculas do tipo MHC (NEUMANN, 2001). Entretanto, o mecanismo pelo qual as células gliais respondem a infecções virais por meio de comunicação celular é pobremente caracterizado (NAIR; DIAMOND, 2015). As quimiocinas são redundantes e a expressão de uma quimiocina no SNC pode induzir a expressão de quimiocinas em outras células (MELCHJORSEN et al., 2003). No presente estudo, as quimiocinas expressadas por astrócitos e micróglia poderiam ter sido induzidas pelas quimiocinas liberadas por neurônios infectados pelo VEVNJ. Quimiocinas neuronais, tais como RANTES e MCP-1 podem ativar tanto astrócitos como a micróglia por meio de receptores correspondentes (DE HAAS et al., 2007). A ativação de células gliais por neurônios tem sido reportada em infecções causadas por vírus neurotrópicos tais como Borna disease virus (BDV). O BDV é um vírus RNA de fita negativa que infecta neurônios, que por sua vez pode liberar partículas virais ou moléculas solúveis resistentes ao calor que ativa astrócitos. A ativação do astrócitos, neste caso, se verificou por meio da expressão de RANTES, a qual foi seguida da ativação de micróglia (OVANESOV et al., 2008).

No presente estudo, RANTES e MCP-1 foram detectadas primeiramente em um número significativo de células no $4 \mathrm{DPI}$, principalmente na camada do nervo olfatório e glomerular do BO. Tardiamente no curso da infecção, houve um aumento do número de células positivas para ambas as quimiocinas no 6 DPI na camada plexiforme externa estendendo-se até a camada granular. Estes resultados são similares àqueles previamente descritos na encefalite por VEV. A expressão de quimiocinas durante a encefalite por VEV em camundongos apresentou um padrão 
bimodal, com o primeiro pico ocorrendo no 3 DPI seguido de outro pico no 6-7 DPI (IRELAND; REISS, 2006; STEEL et al., 2014). Os resultados dos experimentos aqui relatados, demonstraram um padrão de expressão de quimiocinas no $\mathrm{BO}$, no qual se observou incialmente um número significativo de células positivas nas camadas mais externas do $\mathrm{BO}$, as quais são a porta de entrada do vírus. Posteriormente, houve um aumento da expressão das áreas mais internas do $\mathrm{BO}$, o que correlacionou com a cinética da distribuição viral. Semelhantemente, na infecção pelo RABV, a distribuição de MCP-1 estava fortemente correlacionada com a distribuição viral, indicando que quando havia um aumento na quantidade de antígenos virais, havia também um aumento na marcação para MCP-1, ao passo que RANTES teve uma correlação mais fraca com a distribuição de RABV (HICKS et al., 2013). No presente estudo, a infecção pelo VEV no BO de ratos-veadeiros não induziu a expressão de quimiocinas em outras áreas do SNC, o que demonstra que estas quimiocinas podem afetar as células residentes do SNC localmente. Diferentemente, uma reposta distante de interferon do tipo I (IFN-I) em outras áreas do SNC de camundongos inoculados com o VEV protegeu contra a disseminação do vírus para áreas mais caudais do SNC (VAN DEN POL et al., 2014).

No presente estudo, uma lesão do tipo inflamatória significativa surgiu primeiramente no 6 DPI com o aparecimento de manguitos perivasculares compostos por macrófagos e linfócitos. Estas lesões se tornaram mais acentuadas no $7 \mathrm{DPI}$. A primeiro surgimento de uma encefalite severa no 6 DPI demonstra que as quimiocinas RANTES e MCP-1, primeiramente expressas no $4 \mathrm{DPI}$, muito provavelmente contribuíram para a infiltração de células inflamatórias para $0 \mathrm{BO}$. Adicionalmente à expressão de quimiocinas por células residentes do SNC, as células inflamatórias também poderiam exercer um papel importante na produção de quimiocinas no curso mais avançado da encefalite. A encefalite causada por VEV provavelmente é independente de linfócitos T como se observou em camundongos atímicos, sendo que em camundongos normais, os linfócitos T não aparecem no BO antes do 4 DPI (FREl et al., 1989). Este fato demonstra que as células residentes do SNC podem exercer um papel importante na iniciação e progressão da encefalite causada por VEV. Entretanto, outro estudo demonstrou que os linfócitos T podem exercer podem ser a fonte primária de quimiocinas no pico da inflamação (6-8 DPI), porém a participação das células gliais neste momento não pode ser excluída (Steel et al., 2014). Durante a infecção pelo VEV em ratos-veadeiros, as células residentes 
do SNC, tais como neurônios, astrócitos e micróglia, podem exercer um papel importante na iniciação de uma resposta antiviral por meio da expressão das quimiocinas RANTES e MCP-1.

Quando inoculado pela via intranasal em ratos-veadeiros, o VEVNJ-Colorado primeiramente chega às camadas do nervo olfatório e glomerular no $\mathrm{BO}$, as quais recebem axônios dos neurônios olfatórios receptores localizados no epitélio olfatório. Uma vez no BO, VEVNJ se dissemina para as outras camadas, tais como as camadas plexiforme externa, mitral e granular. Entretanto, no presente estudo, o vírus estava restrito ao BO e não se disseminou para outras áreas do SNC. Diversos estudos reportam que o VEV em camundongos wild-type, após a infecção do $\mathrm{BO}$, 0 vírus se dissemina para outras áreas do SNC (SABIN; OLITSKY, 1937; HUNEYCUTT et al., 1994; BI et al., 1995; CHRISTIAN et al., 1996; REISS et al., 1998; CORNISH et al., 2001). Entretanto, é difícil comparar os estudos, uma vez que a idade e linhagens de camundongos, sorotipo do vírus, assim como a quantidade de vírus inoculada diferem entre os estudos. O sorotipo Indiana foi utilizado em diversos estudos, incluindo aqueles que investigam possíveis mecanismos da resposta imune inata os quais são importantes para evitar a disseminação viral no SNC (BI et al., 1995; CHRISTIAN et al., 1996; LANG et al., 2007; DETJE et al., 2009; CHAUHAN et al., 2010; FENSTERL et al., 2012; DETJE et al., 2015). Usualmente nestes estudos, o vírus chega ao BO e se dissemina para outras áreas do SNC dependendo do tipo de imunodeficiência do camundongo utilizado. Nos ratosveadeiros de 3 a 7 semanas de idade, o VEV sorotipo Indiana infecta células do epitélio olfatório quando inoculado pela via intranasal. Entretanto, o vírus permanece restrito à cavidade nasal e não chega ao SNC por meio do $\mathrm{BO}$, demonstrando que o rato-veadeiro pode debelar a infecção viral na cavidade nasal, evitando o desenvolvimento da encefalite (E. W. Howerth, dados não publicados). No presente estudo, uma vez que a infecção pelo VEVNJ-Colorado estava restrita ao $\mathrm{BO}$, a expressão de RANTES e MCP-1 podem exercer um papel importante no intuito de controlar a infecção e disseminação do VEV para outras áreas do SNC, além do BO em ratos-veadeiros. Adicionalmente, inúmeros mecanismos da imunidade inata tais como receptor de IFN tipo I (IFNAR), IFN tipo I (IFN- $\beta$ ), interferon-induced Ifit2/ISG54, fator regulador de interferon - 1 (IRF-1) e MyD88 são importantes para controlar a infecção pelo VEV e evitar a disseminação do vírus no SNC de 
camundongos (LANG et al., 2007; DETJE et al., 2009; FENSTERL et al., 2012; NAIR et al., 2014; VAN DEN POL et al., 2014; DETJE et al., 2015).

\subsection{CONCLUSÕES}

Os experimentos do presente estudo demonstraram que as quimiocinas RANTES e MCP-1 são expressas por células residentes do SNC do BO durante a infecção causada pelo VEVNJ em ratos-veadeiros. Neurônios, astrócitos e micróglia expressaram RANTES, ao passo que MCP-1 foi expresso por neurônios e astrócitos. A disseminação viral nos neurônios do BO procedeu a expressão destas quimiocinas, demonstrando que os neurônios infectados muito provavelmente exercem um papel importante na iniciação da resposta imune no BO. Apesarem de não estarem significativamente infectados pelo VEVNJ, os astrócitos e a micróglia também responderam à infecção ao expressarem quimiocinas. 


\section{REFERÊNCIAS}

ASENSIO, V. C.; CAMPBELL, I. L. Chemokines in the CNS: plurifunctional mediators in diverse states. Trends in Neuroscience, v. 22, n. 11, p. 504-512, 1999.

BI, Z.; BARNA, M.; KOMATSU, T.; REISS, C. S. Vesicular stomatitis virus infection of the central nervous system activates both innate and acquired immunity. Journal of Virology, v. 69, n. 10, p. 6466-6472, 1995.

CARPENTIER, P. A.; GETTS, M. T.; MILLER, S. D. Pro-inflammatory functions of astrocytes correlate with viral clearance and strain-dependent protection from TMEVinduced demyelinating disease. Virology, v. 375, n. 1, p. 24-36, 2008.

CHAUHAN, V.; FURR, S.; STERKA, D.; NELSON, D.; MOERDYK-SCHAUWECKER, M.; MARRIOTT, I.; GRDZELISHVILI, V. Vesicular stomatitis virus infects resident cells of the central nervous system and induces replication-dependent inflammatory responses. Virology, v. 400, n. 2, p. 187-196, 2010.

CHEN, C. J.; CHEN, J. H.; CHEN, S. Y.; LIAO, S. L.; RAUNG, S. L. Upregulation of RANTES gene expression in neuroglia by Japanese encephalitis virus infection. Journal of Virology, v. 78, n. 22, p. 12107-12119, 2004.

CHRISTIAN, A. Y.; BARNA, M.; BI, Z.; REISS, C. S. Host immune response to vesicular stomatitis virus infection of the central nervous system in C57BL/6 mice. Viral Immunology, v 9, n. 3, p. 195-205, 1996.

CORNISH, T. E.; STALLKNECHT, D. E.; BROWN, C. C.; SEAL, B. S.; HOWERTH, E. W. Pathogenesis of experimental vesicular stomatitis virus (New Jersey serotype) infection in the deer mouse (Peromyscus maniculatus). Veterinary Pathology, v. 38, n. 4, p. 396-406, 2001.

DE HAAS, A. H.; VAN WEERING, H. R.; DE JONG, E. K.; BODDEKE, H. W.; BIBER, K. P. Neuronal chemokines: versatile messengers in central nervous system cell interaction. Molecular Neurobiology, v. 36, n. 2, p. 137-151, 2007.

DESHMANE, S.; KREMLEV, S.; AMINI, S.; SAWAYA, B. Monocyte Chemoattractant Protein-1 (MCP-1): An Overview. Journal of Interferon and Cytokine Research, $v$. 29, n. 6, p. 313-326, 2009. 
DETJE, C. N.; LIENENKLAUS, S.; CHHATBAR, C.; SPANIER, J.; PRAJEETH, C. K.; SOLDNER, C.; TOVEY, M. G.; SCHLÜTER, D.; WEISS, S.; STANGEL, M.; KALINKE, U. Upon intranasal vesicular stomatitis virus infection, astrocytes in the olfactory bulb are important interferon Beta producers that protect from lethal encephalitis. Journal of Virology, v. 89, n. 5, p. 2731-2738, 2015.

DETJE, C. N.; MEYER, T.; SCHMIDT, H.; KREUZ, D.; ROSE, J. K.; BECHMANN, I.; PRINZ, M.; KALINKE, U. Local type I IFN receptor signaling protects against virus spread within the central nervous system. Journal of Immunology, v. 182, n. 4, p. 2297-2304, 2009.

DOS SANTOS, A. C.; BARSANTE, M. M.; ARANTES, R. M.; BERNARD, C. C.; TEIXEIRA, M. M.; CARVALHO-TAVARES, J. CCL2 and CCL5 mediate leukocyte adhesion in experimental autoimmune encephalomyelitis--an intravital microscopy study. Journal of Neuroimmunology, v. 162, n.1, p. 122-129, 2005.

FENSTERL, V.; WETZEL, J. L.; RAMACHANDRAN, S.; OGINO, T.; STOHLMAN, S. A.; BERGMANN, C. C.; DIAMOND, M. S.; VIRGIN, H. W.; SEN, G. C. Interferoninduced Ifit2/ISG54 protects mice from lethal VSV neuropathogenesis. PLoS

Pathogens, v 8, n. 5, 2012.

FREI, K.; MALIPIERO, U. V.; LEIST, T. P.; ZINKERNAGEL, R. M.; SCHWAB, M. E.; FONTANA, A. On the cellular source and function of interleukin 6 produced in the central nervous system in viral diseases. European Journal of Immunology, v. 19, n. 4, p. 689-694, 1989.

GETTS, D. R.; TERRY, R. L.; GETTS, M. T.; MÜLLER, M.; RANA, S.; SHRESTHA, B.; RADFORD, J.; VAN ROOIJEN, N.; CAMPBELL, I. L.; KING, N. J. Ly6c+ "inflammatory monocytes" are microglial precursors recruited in a pathogenic manner in West Nile virus encephalitis. Journal of Experimental Medicine, v. 205, n. 10, p. 2319-2337, 2008.

GLENN, J. A.; WARD, S. A.; STONE, C. R.; BOOTH, P. L.; THOMAS, W. E. Characterisation of ramified microglial cells: detailed morphology, morphological plasticity and proliferative capability. Journal of Anatomy, v. 180, n. 1, p. 109-118, 1992.

HICKS, D.; NUNEZ, A.; BANYARD, A.; WILLIAMS, A.; ORTIZ-PELAEZ, A.; FOOKS, A.; JOHNSON, N. Differential Chemokine Responses in the Murine Brain Following Lyssavirus Infection. Journal of Comparative Pathology, v. 149, n. 4, p. 446-462, 2013. 
HOSKING, M. P.; LANE, T. E. The role of chemokines during viral infection of the CNS. PLoS Pathogens, v. 6, n. 7, 2010.

HUNEYCUTT, B. S.; BI, Z.; AOKI, C. J.; REISS, C. S. Central neuropathogenesis of vesicular stomatitis virus infection of immunodeficient mice. Journal of Virology, $v$. 67, n. 11, p. 6698-6706, 1993.

HUNEYCUTT, B. S.; PLAKHOV, I. V.; SHUSTERMAN, Z.; BARTIDO, S. M.; HUANG, A.; REISS, C. S.; AOKI, C. Distribution of vesicular stomatitis virus proteins in the brains of BALB/c mice following intranasal inoculation: an immunohistochemical analysis. Brain Research, v. 635, n. 2, p. 81-95, 1994.

IMAI, T. Construction of functional neuronal circuitry in the olfactory bulb. Seminars in Cell \& Developmental Biology, v. 35, p. 180-188, 2014.

IRELAND, D. D.; REISS, C. S. Gene expression contributing to recruitment of circulating cells in response to vesicular stomatitis virus infection of the CNS. Viral Immunology, v. 19, n. 3, p. 536-545, 2006.

KHIATI, A.; CHALOIN, O.; MULLER, S.; TARDIEU, M.; HORELLOU, P. Induction of monocyte chemoattractant protein-1 (MCP-1/CCL2) gene expression by human immunodeficiency virus-1 Tat in human astrocytes is CDK9 dependent. Journal of Neurovirology, v. 16, n. 2, p. 150-167, 2010.

LANG, K. S.; NAVARINI, A. A.; RECHER, M.; LANG, P. A.; HEIKENWALDER, M.; STECHER, B.; BERGTHALER, A.; ODERMATT, B.; AKIRA, S.; HONDA, K.; HENGARTNER, H.; ZINKERNAGEL, R. M. MyD88 protects from lethal encephalitis during infection with vesicular stomatitis virus. European Journal of Immunology, v. 37 , n. 9 , p. $2434-40$.

LIU, X.; SHAH, A.; GANGWANI, M. R.; SILVERSTEIN, P. S.; FU, M.; KUMAR, A. HIV-1 Nef induces CCL5 production in astrocytes through p38-MAPK and PI3K/Akt pathway and utilizes NF-kB, CEBP and AP-1 transcription factors. Scientific Reports, v. 4, p. 4450, 2014.

LOKENSGARD, J. R.; HU, S.; SHENG, W.; VANOIJEN, M.; COX, D.; CHEERAN, M. C.; PETERSON, P. K. Robust expression of TNF-alpha, IL-1beta, RANTES, and IP10 by human microglial cells during nonproductive infection with herpes simplex virus. Journal of Neurovirology, v. 7, n. 3, p. 208-219, 2001. 
MADRIGAL, J. L.; LEZA, J. C.; POLAK, P.; KALININ, S.; FEINSTEIN, D. L. Astrocyte-derived MCP-1 mediates neuroprotective effects of noradrenaline. Journal of Neuroscience 2009, 29 (1), 263-7.

MELCHJORSEN, J.; SØRENSEN, L. N.; PALUDAN, S. R. Expression and function of chemokines during viral infections: from molecular mechanisms to in vivo function. Journal of Leukocyte Biology, v. 74, n. 3, p. 331-343, 2003.

MORI, K.; NAGAO, H.; YOSHIHARA, Y. The olfactory bulb: coding and processing of odor molecule information. Science, v. 286, n. 5440, p. 711-715, 1999.

MORI, I.; NISHIYAMA, Y.; YOKOCHI, T.; KIMURA, Y. Olfactory transmission of neurotropic viruses. Journal of Neurovirology, v. 11, n. , p. 129-137, 2005.

NAIR, S.; DIAMOND, M. Innate immune interactions within the central nervous system modulate pathogenesis of viral infections. Current Opinion in Immunology, v. 36, p. 47-53, 2015.

NAIR, S.; MICHAELSEN-PREUSSE, K.; FINSTERBUSCH, K.; STEGEMANNKONISZEWSKI, S.; BRUDER, D.; GRASHOFF, M.; KORTE, M.; KÖSTER, M.; KALINKE, U.; HAUSER, H.; KRÖGER, A. Interferon regulatory factor-1 protects from fatal neurotropic infection with vesicular stomatitis virus by specific inhibition of viral replication in neurons. PLoS Pathogens, v. 10, n. 3, 2014.

NAKAMICHI, K.; SAIKI, M.; SAWADA, M.; TAKAYAMA-ITO, M.; YAMAMURO, Y.; MORIMOTO, K.; KURANE, I. Rabies virus-induced activation of mitogen-activated protein kinase and NF-kappaB signaling pathways regulates expression of CXC and $\mathrm{CC}$ chemokine ligands in microglia. Journal of Virology, v. 79, n. 18, p. 11801$11812,2005$.

NEUMANN, H. Control of glial immune function by neurons. Glia, v. 36, n. 2, 191199, 2001.

OVANESOV, M. V.; AYHAN, Y.; WOLBERT, C.; MOLDOVAN, K.; SAUDER, C.; PLETNIKOV, M. V. Astrocytes play a key role in activation of microglia by persistent Borna disease virus infection. Journal of Neuroinflammation, v. 5, n. 50, 2008.

PERSIDSKY, Y.; GHORPADE, A.; RASMUSSEN, J.; LIMOGES, J.; LIU, X.; STINS, M.; FIALA, M.; WAY, D.; KIM, K.; WITTE, M.; WEINAND, M.; CARHART, L.;

GENDELMAN, $\mathrm{H}$. Microglial and astrocyte chemokines regulate monocyte migration 
through the blood-brain barrier in human immunodeficiency virus-1 encephalitis. American Journal of Pathology, v. 155, n. 5, p. 1599-1611, 1999.

PLAKHOV, I. V.; ARLUND, E. E.; AOKI, C.; REISS, C. S. The earliest events in vesicular stomatitis virus infection of the murine olfactory neuroepithelium and entry of the central nervous system. Virology, v. 209, n. 1, p. 257-262, 1995.

PRÉHAUD, C.; MÉGRET, F.; LAFAGE, M.; LAFON, M. Virus infection switches TLR3-positive human neurons to become strong producers of beta interferon. Journal of Virology, v. 79, n. 20, p. 12893-12904, 2005.

REISS, C.; CHESLER, D.; HODGES, J.; IRELAND, D.; CHEN, N.; DIETZSCHOLD, B.; RICHT, J. Innate immune responses in viral encephalitis. Protective and Pathological Immune Responses in the Cns, v. 265, p. 63-94, 2002.

REISS, C. S.; PLAKHOV, I. V.; KOMATSU, T. Viral replication in olfactory receptor neurons and entry into the olfactory bulb and brain. Annals of New York Academy Sciences, v. 855, p. 751-761, 1998.

SABIN, A. B.; OLITSKY, P. K. Influence of host factors on neuroinvasiveness of vesicular stomatitis virus : I. Effect of age on the invasion of the brain by virus instilled in the nose. Journal of Experimental Medicine, v. 66, n. 1, p. 15-34, 1937.

STEEL, C.; BREVING, K.; TAVAKOLI, S.; KIM, W.; SANFORD, L.; CIAVARRA, R. Role of peripheral immune response in microglia activation and regulation of brain chemokine and proinflammatory cytokine responses induced during VSV encephalitis. Journal of Neuroimmunology, v. 267, n.2, p. 50-60, 2014.

TERRY, R. L.; GETTS, D. R.; DEFFRASNES, C.; VAN VREDEN, C.; CAMPBELL, I. L.; KING, N. J. Inflammatory monocytes and the pathogenesis of viral encephalitis. Journal of Neuroinflammation, v. 9, p. 270, 2012.

TRIPATHY, D.; THIRUMANGALAKUDI, L.; GRAMMAS, P. RANTES upregulation in the Alzheimer's disease brain: a possible neuroprotective role. Neurobiology of Aging, v. 31, n. 1, p. 8-16, 2010.

VAN DEN POL, A. N.; DING, S.; ROBEK, M. D. Long-distance interferon signaling within the brain blocks virus spread. Journal of Virology, v. 88, n. 7, p. 3695-3704, 2014. 
VILELA, M. C.; MANSUR, D. S.; LACERDA-QUEIROZ, N.; RODRIGUES, D. H.; LIMA, G. K.; ARANTES, R. M.; KROON, E. G.; DA SILVA CAMPOS, M. A.; TEIXEIRA, M. M.; TEIXEIRA, A. L. The chemokine CCL5 is essential for leukocyte recruitment in a model of severe Herpes simplex encephalitis. Annals of New York Academy Sciences, v. 1153, p. 256-263, 2009.

ZHAO, P.; YANG, Y.; FENG, H.; ZHAO, L.; QIN, J.; ZHANG, T.; WANG, H.; YANG, S.; XIA, X. Global gene expression changes in BV2 microglial cell line during rabies virus infection. Infection Genetics and Evolution, v. 20, p. 257-269, 2013.

ZLOTNIK, A.; YOSHIE, O. Chemokines: A new classification system and their role in immunity. Immunity, v. 12, n. 2, p. 121-127, 2000. 


\title{
Pathogenesis of Vesicular Stomatitis New Jersey Virus Infection in Deer Mice (Peromyscus maniculatus) Transmitted by Black Flies (Simulium vittatum)
}

Veterinary Pathology (c) The Author(s) 2016 Reprints and permission: DOI: $10.1177 / 0300985816653172$ vet.sagepub.com

\author{
L. P. Mesquita',2,", M. H. Diaz,4,", E. W. Howerth', \\ D. E. Stallknecht ${ }^{3}$, R. Noblet ${ }^{5}$, E. W. Gray, and D. G. Mead ${ }^{3}$
}

\begin{abstract}
The natural transmission of vesicular stomatitis New Jersey virus (VSNJV), an arthropod-borne virus, is not completely understood. Rodents may have a role as reservoir or amplifying hosts. In this study, juvenile and nestling deer mice (Peromyscus maniculatus) were exposed to VSNJV-infected black fly (Simulium vittatum) bites followed by a second exposure to naive black flies on the nestling mice. Severe neurological signs were observed in some juvenile mice by 6 to 8 days postinoculation (DPI); viremia was not detected in 25 juvenile deer mice following exposure to VSNJV-infected fly bites. Both juvenile and nestling mice had lesions and viral antigen in the central nervous system (CNS); in juveniles, their distribution suggested that the sensory pathway was the most likely route to the CNS. In contrast, a hematogenous route was probably involved in nestling mice, since all of these mice developed viremia and had widespread antigen distribution in the CNS and other tissues on 2 DPI. VSNJV was recovered from naive flies that fed on viremic nestling mice. This is the first report of viremia in a potential natural host following infection with VSNJV via insect bite and conversely of an insect becoming infected with VSNJV by feeding on a viremic host. These results, along with histopathology and immunohistochemistry, show that nestling mice have widespread dissemination of VSNJV following VSNJV-infected black fly bite and are a potential reservoir or amplifying host for VSNJV.
\end{abstract}

\section{Keywords}

arbovirus, arthropod-borne virus, deer mouse, encephalitis, vesicular stomatitis virus, neuropathogenesis, transmission, reservoir host

Vesicular stomatitis New Jersey virus (VSNJV) is an arthropodborne virus in the genus Vesiculovirus, family Rhabdoviridae, that primarily affects horses, cattle, and swine, yet many other animal species are also susceptible to infection, including wildlife. ${ }^{17}$ Infections in livestock are characterized by the development of vesicular lesions on the mouth, teats, and coronary bands, which are clinically indistinguishable from lesions of foot-and-mouth disease in cattle and pigs. ${ }^{11}$

Infection of domestic animals with VSNJV has occurred as small endemic foci on Ossabaw Island, Georgia, as well as in parts of southern Mexico, Costa Rica, and northern South America. ${ }^{1,2}$ In addition, VSNJV is associated with recurrent vesicular stomatitis (VS) epidemics in the western United States. $^{11}$

Transmission is associated with animal-to-animal contact and infected biting insects, such as sand flies (Lutzomyia spp) ${ }^{15}$, biting midges (Culicoides spp) ${ }^{10}$ and black flies (Simulium $s p p) .{ }^{3,6,7}$ However, several aspects of transmission by insects remain unclear, including how the virus is maintained between outbreaks and from what source insects are initially infected.
Serologic surveys to identify potential reservoir species involved in enzootic VSNJV maintenance have shown that mammals, including ungulates, carnivores, and rodents, may be naturally infected with VSNJV. ${ }^{17}$ Of these susceptible species, only rodents have been shown to consistently develop viremia following experimental infection. ${ }^{2}$ Based on serologic

'Department of Pathology, University of Georgia, Athens, GA, USA 2Department of Pathology, University of São Paulo, São Paulo, Brazil ${ }^{3}$ Southeastern Cooperative Wildlife Disease Study, College of Veterinary Medicine, University of Georgia, Athens, GA, USA

${ }^{4}$ Centers for Disease Control and Prevention, Division of Bacterial Diseases, Respiratory Diseases Branch, Atlanta, GA, USA

${ }^{5}$ Department of Entomology, University of Georgia, Athens, GA, USA

*These authors contributed equally to this manuscript.

Corresponding Author:

E. W. Howerth, Department of Pathology, University of Georgia, 50I D.W. Brooks Dr, Athens, GA 30602, USA.

Email: howerth@uga.edu 
studies ${ }^{17}$ and experimental infections, ${ }^{2}$ the deer mouse (Peromyscus maniculatus) has been implicated as a potential VSNJV reservoir host. Naturally infected deer mice have been associated both temporally and spatially with the occurrence of VS epizootics. ${ }^{17}$ Experimental infection demonstrated that deer mice can develop viremia and central nervous system (CNS) disease following intranasal or intradermal inoculation. ${ }^{2}$ The virus also can be transmitted from VSNJV-infected black flies to naive black flies that are physically separated while cofeeding on deer mice, even though the mice do not develop detectable viremia. ${ }^{7}$ In livestock, VSNJV can be transmitted mechanically to domestic pigs by black flies that had fed at the site of vesicular lesions in a previously infected host. ${ }^{18}$ In addition, in cattle, VSNJV-infected black flies can transmit the virus to a naive host and cause clinical disease. 19,20

While the presence of neutralizing antibodies in animals demonstrates their susceptibility to VSNJV infection, it does not fully implicate them as reservoirs. According to the World Health Organization (WHO), a reservoir species must have virus circulating in the bloodstream at levels sufficient to infect a blood-feeding vector. ${ }^{21}$ Detectable VSNJV viremia has been reported in rodents following direct and peripheral infection routes ${ }^{2,16}$ but never following transmission via infected insect bite. Neither transmission accompanied by viremia in a host nor transmission to insects from a viremic host has been documented previously for VSNJV in any vector-host relationship. The present study was designed to evaluate the susceptibility of juvenile and nestling deer mice to VSNJV infection via black fly bite and also the ability of these mice to transmit the virus to naive black flies.

\section{Materials and Methods}

Two- to 3-day-old female Simulium vittatum (IS-7 cytotype) from a continuous laboratory colony (Department of Entomology, University of Georgia, Athens, Georgia) were used in this study. Peromyscus maniculatus were obtained from the Peromyscus Stock Center (Columbia, South Carolina) and housed individually in microisolation cages under controlled temperature conditions. The use of animals in this study was approved by the University of Georgia's Institutional Animal Care and Use Committee (approval A2001-10076-ml). A 1997 Colorado equine VSNJV isolate was used in these studies. The virus was passaged and titrated in confluent Vero Middle America Research Unit (MARU, [Vero-M]) cell culture monolayers. ${ }^{6}$

\section{Experimental Design}

Two separate experiments were conducted. In the first experiment, 20 female juvenile mice (aged 26-28 days) were separated into 2 groups (10 mice/group). The mice of group 1 (case Nos. 1-10) were anesthetized with $45 \mathrm{mg} / \mathrm{kg}$ Telazol (Zoetis, Florham Park, New Jersey) and $7.5 \mathrm{mg} / \mathrm{kg}$ xylazine and were intranasally infected with a suspension of VSNJV $\left(10^{7} \mathrm{pfu} / \mathrm{ml}\right)$ by placing a drop of the suspension at the opening to the nasal cavity, stimulating the mouse to inhale the droplet. On 1 or
2 days postinoculation (DPI), naive female black flies were allowed to feed on the intranasally infected mice (20-40 flies/mouse), and blood samples were collected in heparinized capillary tubes from the orbital sinus of mice and centrifuged to separate serum for virus isolation. Of these mice, 6 and 4 mice were euthanized on 1 and 2 DPI, respectively, immediately after blood sampling and fly feeding. In addition, following feeding, flies were collected for virus isolation. Group 2 mice (case Nos. 11-20) were anesthetized as described above, and the abdomen was shaved to expose skin, facilitating direct contact for insect feeding. Black flies, infected with VSNJV as previously described, ${ }^{7}$ were allowed to feed on the shaved abdomen of each mouse until they no longer showed interest in feeding or until the anesthesia began to subside. To determine how many VSNJV-infected flies had fed on each mouse, black flies were dissected and examined for the presence of blood in the abdomen immediately after being allowed to feed on mice. Blood samples were collected in heparinized capillary tubes from the orbital sinus of all mice on 1 or 2 DPI, then centrifuged to separate serum for virus isolation. Then, 6 and 4 mice were euthanized on 1 and 2 DPI, respectively.

In a second experiment, 15 female juvenile mice (aged 26-28 days) and 8 nestling mice (aged 6-7 days) were used. Fifteen juvenile (group 3/case Nos. 21-35) deer mice were exposed to VSNJV-infected fly bite as described for group 2 above. Mice were observed daily for onset of clinical illness indicated by rapid breathing and/or paralysis in the hind legs. Mice with severe neurological signs $(n=4)$ were immediately euthanized. Six and 5 juvenile mice not showing clinical signs were euthanized on 10 and 11 DPI, respectively. Blood collected from the orbital sinus from these mice on 3 DPI and at euthanasia was processed for viral isolation and antibody titration. Eight nestling mice (group 4/case Nos. 36-43) were housed with the mother in a single microisolation cage. VSNJV-infected flies were allowed to feed on the anesthetized nestlings without shaving the abdomen since they had not developed a significant amount of fur. Subsequently, these mice were divided in 2 subgroups of 4 animals each, and naive flies were allowed to feed on anesthetized nestlings on 1 and 2 DPI, respectively. Immediately following feeding, the mice were euthanized as described above, and the flies were submitted for dissection and viral isolation. Flies with obvious swelling of the abdomen indicating blood feeding were homogenized individually.

All mice were euthanized by subcutaneous injection of barbiturate. Necropsy was performed in all euthanized mice and mice that died from both experiments, and samples of head, brain, spinal cord, skin, lung, and heart were collected and fixed in $10 \%$ neutral buffered formalin. In addition, samples of brain of nestling mice were collected for viral isolation.

\section{Virus Isolation, RT-PCR, and Antibody Titration}

Black flies were homogenized in groups of 1 to 3 black flies in 1.8-ml vials each containing 2 copperhead ball-bearing pellets and $0.5 \mathrm{ml}$ virus isolation media (minimum essential media [MEM] with $5 \%$ fetal bovine serum and $2 \%$ antibiotics). For 
virus isolation, either $10 \mu \mathrm{l}$ of serum or black fly samples was inoculated onto individual wells of a 12 -well plate with confluent Vero-M cell culture monolayers and incubated at $37^{\circ} \mathrm{C}$ in a $5 \% \mathrm{CO}_{2}$ atmosphere for 1 hour. Cell cultures were examined daily for 3 days for evidence of cytopathic effects (CPE). Before inoculation, black fly samples were centrifuged to settle debris, and $100 \mu \mathrm{l}$ of the resulting supernatant was used for virus isolation. Virus isolates were confirmed by reverse transcriptase polymerase chain reaction (RT-PCR) as described previously. $^{12}$

A previously described plaque assay ${ }^{6}$ was used to quantify VSNJV in virus isolation-positive black fly and serum samples. Briefly, 10-fold serial dilutions of positive serum or black fly samples were used as the cell culture inoculum. Two $0.5-\mathrm{ml}$ portions of each dilution were aliquoted onto each of 2 wells of 2-day-old confluent Vero-M cell culture monolayers in 24-well cell culture plates and incubated at $37^{\circ} \mathrm{C}$ for 1 hour. After removal of the inoculum, the cells were overlaid with a $1 \%$ gum tragacanth/1 $\times$ MEM solution supplemented with $3 \%$ heat-inactivated fetal bovine serum and $2 \times$ antibiotic/antimycotic $(200 \mathrm{U} / \mathrm{ml}$ penicillin, $200 \mu \mathrm{g} / \mathrm{ml}$ streptomycin, and 500 $\mathrm{ng} / \mathrm{ml}$ amphotericin B). After incubating for 3 days at $37^{\circ} \mathrm{C}$, cells were fixed by adding $20 \%$ formalin to the overlay and then stained with $5 \%$ crystal violet. Virus titers are expressed as plaque-forming units (pfu) per black fly or milliliters of serum.

Antibody titration was performed using a microtiter serum neutralization test. ${ }^{9}$ Briefly, for microtiter serum neutralization tests, 2-fold dilutions (maximum 1:256) of heat-inactivated serum samples were challenged with a virus solution (1000 $\left.\mathrm{TCID}_{50} / 25 \mu \mathrm{l}\right)$ to identify an increase in VSNJV neutralizing antibodies. A 4-fold or greater increase in neutralizing antibodies was considered evidence of seroconversion.

\section{Histology and Immunohistochemistry}

Formalin-fixed tissues were embedded in paraffin, sectioned at $4 \mu \mathrm{m}$, and stained with hematoxylin and eosin. Tissue sections from juvenile mice from the first experiment (case Nos. 1 and 2 /intranasal infection; case Nos. 11, 13-17, and 20/infection by fly bite), as well as from mice of the second experiment (case Nos. 21, 23, 25, 26, 31, 32, and 34/juveniles; case Nos. 35-43/ nestlings), were also stained for VSNJV antigen by immunohistochemistry (IHC).

Immunohistochemistry was performed using an alkaline phosphatase-conjugated streptavidin-biotin technique similar to what has been described and validated previously. ${ }^{2}$ Tissues were sectioned at $4 \mu \mathrm{m}$, mounted on slides, and deparaffinized, and antigen was retrieved by boiling in $0.01 \mathrm{M}$ citrate buffer $(\mathrm{pH} 6)$ for 7 minutes in a microwave oven. Sections were blocked with Power Block (Biogenex, Fremont, California) for 7 minutes at room temperature and then incubated with a 1:1500 dilution of anti-VSNJV hyperimmune mouse ascitic fluid kindly provided by Dr. R. B. Tesh. Sections were washed, and biotinylated anti-mouse and alkaline phosphatase-conjugated streptavidin label (Biogenex, San Ramon, California) were used sequentially. Fast red (Biogenex) was used as the chromagen/substrate, and sections were counterstained with hematoxylin. CNS sections of mice previously infected with VSNJV were used as positive controls. ${ }^{2}$ The primary antibody was substituted by homologous nonimmune sera as a negative control.

\section{Results}

\section{Clinical Outcome}

One juvenile mouse (case No. 10) from group 1 was found deceased on $1 \mathrm{DPI}$, probably due to trauma during the manipulation process. Clinical disease, characterized by neurological signs including rapid breathing and/or paralysis originating in the hind legs, developed in 5 juvenile mice that were exposed to VSNJV via fly bite (group 3/case Nos. 21, 23, 25, 26, and 31) One mouse was found deceased (case No. 26) and the other mice were euthanized on 6 to 8 DPI due to severe neurological signs. Juvenile mice from groups 1 and 2 did not exhibit clinical signs since they were euthanized on 1 or 2 DPI. Clinical signs similar to group 3 were observed in the nestling mice (group 4).

\section{Virus Isolation and Seroconversion}

Virus was detected in the serum on 1 or 2 DPI in 9 of 10 intranasally infected group 1 mice by virus isolation and confirmed by RT-PCR. Virus titers in the serum of these mice ranged from $7.5 \times 10^{2}$ to $7.5 \times 10^{4} \mathrm{pfu} / \mathrm{ml}$. However, virus was not recovered from any naive black flies that fed on the viremic mice ( $0 / 266$ flies).

Poor feeding by VSNJV-infected black flies was observed for group 2 mice. Based on observation during dissection, the number of flies containing discernible amounts of blood in the abdomen ranged from 0 to 3 flies per mouse. Viremia was not detected in the serum of any of these mice on 1 or 2 DPI.

Virus was not detected in the serum of any juvenile mice (group 3) exposed to VSNJV via infected fly bite on 3, 10, or 11 DPI. Although viremia was not detected, transmission was confirmed by seroconversion in 7 mice (case Nos. 21, 23, 25, $27,31,32$, and 34). Neutralizing antibody levels for all mice were $<1: 8$ on 3 DPI, and a 4 -fold or greater increase in neutralizing antibody titer was considered seroconversion. Neutralizing antibody titers ranged from $1: 16$ to $1: \geq 256$, and titers in the 5 mice that developed clinical illness included both extremes of this range. The 3 mice that seroconverted but did not demonstrate clinical signs of illness (Nos. 27, 32, and 34) had neutralizing antibody titers of $1: 32,1: 64$, and $1: \geq 256$, respectively.

In group 4 , virus was detected in the serum of 8 of 8 nestling mice on 1 and 2 DPI with virus titers ranging from $1.0 \times 10^{4}$ to $9.5 \times 10^{6} \mathrm{pfu} / \mathrm{ml}$. In addition, VSNJV was detected in the brain of all 8 nestling mice by virus isolation and confirmed by RT-PCR. Virus was recovered from $12 \%(15 / 126)$ of the total number of naive flies allowed to feed on all viremic nestling mice; of these, virus was recovered from $24 \%(15 / 63)$ of those 
Table I. Transmission of Vesicular Stomatitis New Jersey Virus (VSNJV) Between Viremic Nestling Deer Mice and Black Flies. ${ }^{a}$

\begin{tabular}{|c|c|c|c|c|}
\hline $\begin{array}{l}\text { Mouse } \\
\text { No. }\end{array}$ & $\begin{array}{l}\text { Virus Titer }^{\mathrm{b}} \\
\text { in Mouse } \\
\text { Serum, pfu/ml }\end{array}$ & $\begin{array}{l}\text { Fly } \\
\text { No. }\end{array}$ & $\begin{array}{c}\text { Virus Titer } \\
\text { in the Fly, } \\
\text { pfu/ml }\end{array}$ & $\begin{array}{l}\text { Flies Infected/ } \\
\text { Flies Fed, } \\
\text { No. (\%) }\end{array}$ \\
\hline $36^{c}$ & $1.0 \times 10^{4}$ & NA & NA & $0 / 15(0)$ \\
\hline \multirow[t]{3}{*}{$37^{c}$} & $3.0 \times 10^{5}$ & 16 & $<50$ & $3 / 6(50)$ \\
\hline & & 17 & $1.6 \times 10^{3}$ & \\
\hline & & 18 & $1.4 \times 10^{3}$ & \\
\hline \multirow[t]{2}{*}{$38^{c}$} & $2.5 \times 10^{4}$ & 26 & $1.5 \times 10^{2}$ & $2 / 8(25)$ \\
\hline & & 31 & $<50$ & \\
\hline $39^{c}$ & $6.5 \times 10^{4}$ & 46 & $<50$ & I/I2 (8) \\
\hline $40^{d}$ & $3.4 \times 10^{5}$ & NA & NA & $0 / 3(0)$ \\
\hline \multirow[t]{2}{*}{$4 I^{d}$} & $6.5 \times 10^{5}$ & 51 & $<50$ & $2 / 5(40)$ \\
\hline & & 54 & $4.0 \times 10^{2}$ & \\
\hline \multirow[t]{3}{*}{$42^{d}$} & $9.5 \times 10^{6}$ & 63 & $<50$ & $3 / 5(60)$ \\
\hline & & 65 & $<50$ & \\
\hline & & 66 & $<50$ & \\
\hline \multirow[t]{4}{*}{$43^{d}$} & $2.2 \times 10^{6}$ & 71 & $<50$ & 4/9 (44) \\
\hline & & 72 & $<50$ & \\
\hline & & 73 & 50 & \\
\hline & & 78 & $<50$ & \\
\hline
\end{tabular}

Abbreviations: NA, not applicable.

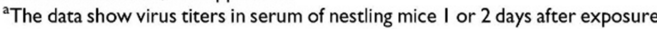
The fin she and the tiers and prevalece of virus recovery from a different cohort of previously uninfected flies after virus recovery from a differenting on the nestling mice.

feeding on the nestling mice.
baive black flies were allowed to feed on VSNJV-infected nestling mice on day ${ }^{\mathrm{C}} \mathrm{Naiv}$ black flies were allowed to feed on
$2^{\mathrm{d}}$ after infection of the mouse.

flies that were suspected of having had a blood feeding. The nestling mouse (case No. 42) with the highest virus titer produced the highest percentage $(60 \%)$ of VSNJV-infected flies, and the lowest virus titer was correlated to the lowest percentage of VSNJV-infected flies (Table 1). One nestling (case No. 40) was an exception to this observation since only 3 flies fed on this mouse. Virus titers of flies that fed on viremic nestlings were determined immediately after feeding and varied from $<50$ to $1.6 \times 10^{3} \mathrm{pfu} / \mathrm{ml}$. As shown in Table 1 , virus titers in VSNJV-infected flies were not directly proportionate to virus titers of nestling mice. The flies with the highest quantity of virus detected were not infected from the mouse with the highest virus titer. Overall, virus was recovered from a higher percentage of flies after feeding on nestlings with virus titers $\geq 10^{5} \mathrm{pfu} / \mathrm{ml}$.

\section{Histopathology and Immunohistochemistry}

Group I. All 10 mice inoculated intranasally had lesions in the nasal cavity that ranged from multifocal necrosis of the olfactory mucosa on 1 DPI to extensive necrosis with a mild to moderate infiltration of neutrophils in the submucosa in mice on 2 DPI. Three of the 6 mice euthanized on 1 DPI had dermatitis at the site of fly bite characterized by focal, mild infiltrations of neutrophils, mononuclear cells, and mast cells in the superficial dermis associated with edema in 1 mouse. On 1 DPI, 1 mouse developed a severe, diffuse purulent bronchiolitis and bronchopneumonia. On 2 DPI, mice had multifocal pyknotic cellular debris in multiple olfactory nerve fibers as they entered the olfactory bulb. IHC was performed on 2 mice (case Nos. 1 and 2), and both had multifocal staining for VSNJV in the olfactory epithelium and in Bowman's glands. Both of these mice also had staining of olfactory nerve fibers from the nasal mucosa to the level of the olfactory bulb. Skin, lung, and brain were immunonegative for VSNJV in these 2 animals.

Group 2. Of the first group of 10 juvenile mice exposed to VSNJV-infected fly bites, 3 of 6 mice on 1 DPI and 2 of 4 mice on 2 DPI had dermatitis at the area of feeding. This was characterized by multifocal serocellular crusting $(5 / 5)$, mild epidermal hyperplasia $(2 / 5)$, and diffuse and mild infiltration of a mixed population of inflammatory cells within the superficial dermis that was composed mainly of macrophages, plasma cells, and neutrophils, as well as fewer lymphocytes and mast cells $(5 / 5)$. Two of these mice had staining for VSNJV by IHC. One (case No. 13) had staining within adipocytes and hair follicles, and another mouse (case No. 20) had staining in the cytoplasm of epidermal keratinocytes and in inflammatory cells in the superficial dermis. In group 2, lesions were not present in brain, spinal cord, nasal mucosa, lung, and heart. Viral antigen was not visualized in these tissues.

Group 3. In the other 15 juvenile mice exposed to VSNJVinfected fly bites, dermatitis at the site of feeding occurred in 5 of the mice, 4 of which (case Nos. 21, 23, 25, and 26) became sick or died. The dermatitis visualized in group 3 was similar as described for group 2. However, viral antigen was not detected in the skin of mice of group 3 by IHC. Only the 4 mice that became sick or died had lesions in the CNS.

In the spinal cord, there was moderate to severe, multifocal to coalescing infiltration of lymphocytes and plasma cells admixed with rare neutrophils in the leptomeninges, severe necrosis of ependymal cells lining the central canal, and multifocal neuronal necrosis affecting both dorsal and ventral horns (Fig. 1). Neuronal necrosis associated with neutrophilic infiltration was also observed in the spinal ganglia (Fig. 2).

In the brain, lymphoplasmacytic leptomeningitis was most severe in the brainstem but affected the entire brain, including olfactory bulbs, and was most severe ventrally. The lesions were characterized by diffuse infiltration of a large number of neutrophils, severe multifocal neuronal necrosis (Fig. 3) in which necrotic neurons were often surrounded by neutrophils, and multifocal areas of hemorrhage. Necrosis of ependymal cells lining the fourth ventricle was also observed.

By immunohistochemistry, strong cytoplasmic immunolabeling for VSNJV antigen was detected in necrotic and viable neurons and their processes throughout the spinal cord (Fig. 4), in brainstem nuclei, and in dorsal root ganglia. VSNJV antigen was also detected in a large number of necrotic and viable ependymal cells lining the central canal of the spinal cord and the fourth ventricle. One mouse (case No. 26) had immunostaining for VSNJV in olfactory nerves, but there were no histopathologic changes in these nerves. Lesions and/or viral 


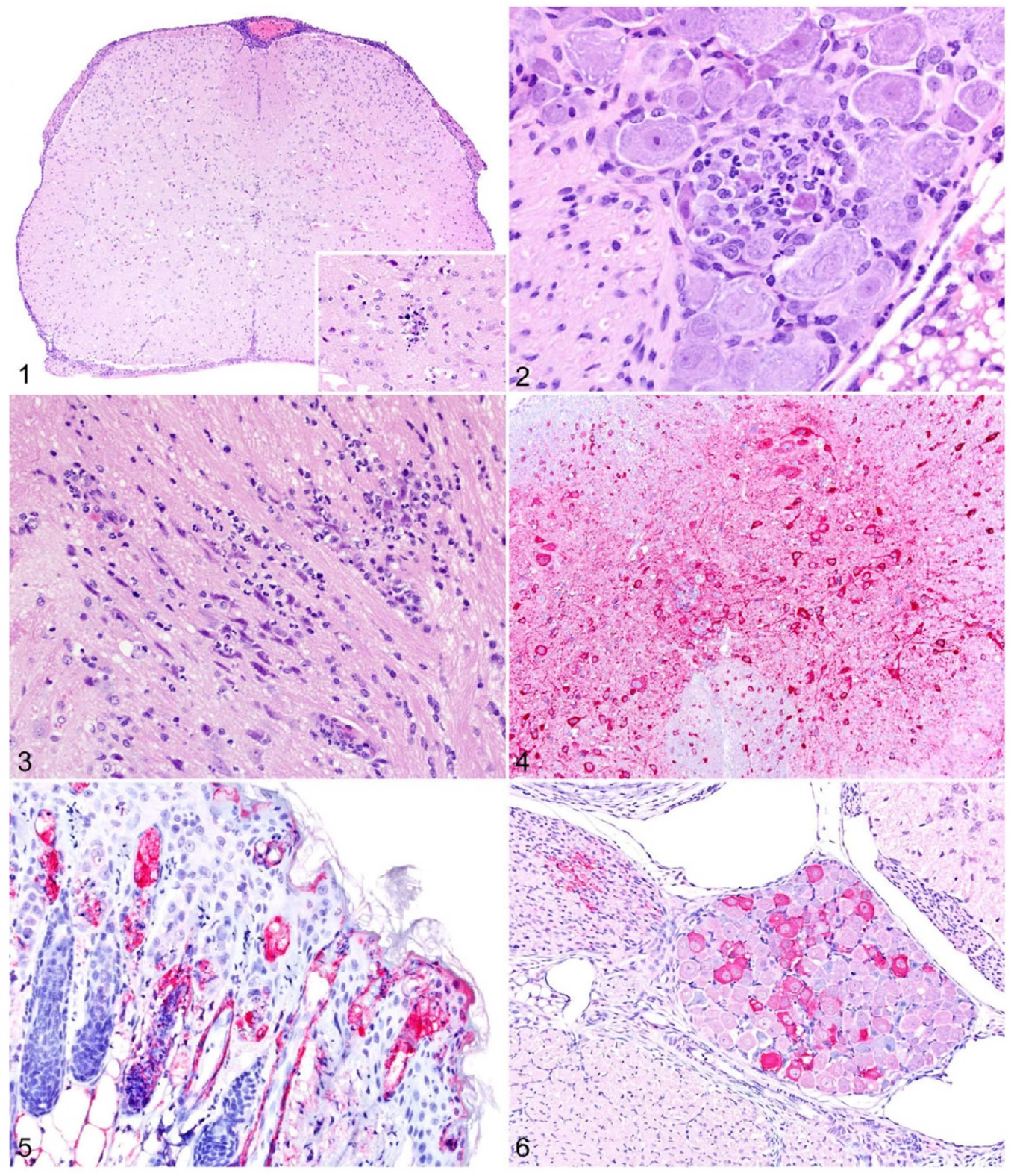

Figures 1-6. Deer mice infected with vesicular stomatitis New Jersey virus (VSNJV) via black fly bite. Figure I. Lymphoplasmacytic leptomeningitis, spinal cord, juvenile mouse at 7 days postinfection (DPI). The leptomeninges are expanded by lymphocytes and plasma cells. Inset: Necrosis of neurons and of ependymal cells lining the central canal. Hematoxylin and eosin (HE). Figure 2. Ganglioneuritis, dorsal root ganglion, juvenile mouse at 6 DPI. Neuronal necrosis with focal neutrophilic infiltration. HE. Figure 3. Encephalitis with neuronal necrosis, brainstem, juvenile mouse at 7 DPI. Neutrophils surround necrotic neurons, which are shrunken and eosinophilic. HE. Figure 4. Spinal cord, juvenile 
antigen were not detected in the olfactory bulb, cranial nerve ganglia, nasal mucosa, heart, lung, skeletal muscle, brown fat, or tongue epithelium of juvenile mice.

Group 4. In the group of nestling mice exposed to VSNJVinfected fly bites, skin lesions were seen in 5 (case Nos. 36, 37, 41, 42, and 43). On 1 DPI, in 2 mice (case Nos. 36 and 37), multifocal areas of hemorrhage were observed in the skin, but viral antigen was not detected. Three of 4 mice euthanized on 2 DPI had skin lesions. One (case No. 42) had a diffuse and mild lymphoplasmacytic and neutrophilic dermatitis without detectable viral antigen, and 1 had a moderate lymphoplasmacytic dermatitis and subcutaneous edema with a small amount of detectable viral antigen (case No. 43). One mouse (case No. 41) had extensive serocellular crusting and severe dermal and subcutaneous edema with severe neutrophilic infiltration and exocytosis. In this nestling, massive amounts of viral antigen were observed multifocally within hair follicles and adipocytes (Fig. 5), and underlying panniculus muscle fibers were positive for VSNJV by IHC.

All nestling mice in group 4 euthanized on 2 DPI had microscopic lesions in the CNS characterized by necrosis of ependymal cells lining the central canal of the spinal cord, the fourth ventricle, and the lateral ventricles. The capillaries throughout the brain were diffusely and markedly congested with swollen endothelial cells. Occasionally, the capillaries were surrounded by a small number of neutrophils, and there were multifocal areas of hemorrhage. There were a small number of neutrophils and lymphocytes within the leptomeninges.

By IHC, all nestling mice in group 4 euthanized at 1 DPI had a VSNJV immunolabeling of few neurons in dorsal root ganglia, in axons of the spinal nerve (Fig. 6), and in few scattered positive neurons in the cerebral cortex, cerebellum, brainstem, and olfactory bulb. On 2 DPI, massive amounts of viral antigen were detected in many neurons throughout the brain, including the cerebral cortex, hippocampus, olfactory bulb, brainstem, and thalamus. Immunolabeling was also present in many neurons in dorsal and ventral horns of spinal cord and dorsal root ganglia and trigeminal ganglia, as well as in olfactory nerves.

Lesions were not observed in the nasal respiratory mucosa, but 6 of 7 nestling mice had detectable viral antigen in the olfactory epithelium and Bowman's gland. Multifocal areas of myocardial necrosis containing massive amounts of viral antigen were seen in 5 of 7 nestling mice. On 2 DPI, 3 mice had multifocal, moderate necrosis of striated muscles around the spinal column, muscles of the head, and tongue; these muscles contained a large amount of viral antigen. VSNJV antigen was also observed in areas of striated or myocardial muscle without lesions. Immunolabeling was also seen in brown fat of 2 mice (case Nos. 40 and 43) associated with or without foci of necrosis. Although lung lesions were not observed, there was multifocal immunolabeling for VSNJV in alveolar septa in 2 of 7 nestling mice (case Nos. 39 and 43).

\section{Discussion}

In this study, both juvenile and nestling deer mice developed CNS disease after exposure to VSNJV-infected black fly bites. The morphologic and immunohistochemical findings suggest that VSNJV in juvenile deer mice reached the CNS via sensory nerves, whereas in nestling mice, the hematogenous route was also involved since these mice developed viremia. Importantly, these viremic nestling mice were able to transmit the virus to naive black flies, establishing 2 essential aspects of arboviral transmission. Although viremia was also detected in juvenile deer mice intranasally infected with VSNJV, the virus titers were not sufficient to infect blood-feeding flies, which suggests that specific host and vector factors may enhance virus replication and transmission in nestling mice.

In the present study, juvenile and nestling deer mice exposed to VSNJV-infected flies developed severe lesions in the CNS. Juvenile mice (group 3) exposed to VSNJV-infected flies were euthanized on 6 to 8 DPI due to severe neurological signs. Lesions in these mice were characterized by a diffuse lymphoplasmacytic leptomeningitis, necrosis of ependyma cells lining the central canal in the spinal cord, and multifocal neuronal necrosis associated with an infiltration of neutrophils in dorsal root ganglia, in both ventral and dorsal horns of the spinal cord and in a large number of neurons of the brainstem. Viral antigen was detected by IHC in the cytoplasm of viable and necrotic neurons of all these areas, including the axons of spinal nerves. No other lesions, or VSNJV antigen, were observed in other tissues. Despite dermatitis visualized in some mice, VSVNJ antigen was not detected in skin on 6 to $8 \mathrm{DPI}$ However, on 1 and 2 DPI, juvenile mice exposed to VSNJVinfected fly bites (group 2) had detectable VSNJV antigen in epithelial cells within the epidermis, in inflammatory cells, and in the dermis.

The presence of VSNJV antigen in the skin supports the hypothesis that when juvenile mice are exposed to VSNJVinfected flies, VSNJV reaches the spinal cord through peripheral nerves via the sensory pathway, whose receptors are located on or near the body surface. ${ }^{4}$ In this way, the virus may first reach the dorsal root ganglia as suggested by the presence of VSNJV antigen on neurons and extending axons. Projections of neurons of the dorsal root ganglia enter the spinal cord through the dorsolateral sulcus and synapse with interneurons involved in reflex activity or with neurons that project cranially to the brainstem. ${ }^{4}$ Large amounts of VSNJV antigen were found in neurons throughout the brainstem, consistent with involvement of the sensory pathway in VSNJV pathogenesis. In addition, the presence of viral antigen in ependymal cells

Figure 4. (continued) mouse at 7 DPI. VSNJV antigen is located within the cytoplasm of neurons of ventral and dorsal horns. Immunohistochemistry (IHC) for VSNJV. Figure 5. Haired skin, nestling mouse at 2 DPI. VSNJV antigen is present in the cytoplasm of epithelial cells of epidermis and hair follicles, as well as of adipocytes. IHC for VSNJV. Figure 6. Dorsal root ganglion, nestling mouse at 2 DPI. Neurons in the ganglion and axons of the spinal nerve are positive for VSNJV antigen. IHC for VSNJV. 
lining the fourth ventricle and central canal of spinal cord suggests that dissemination within the ventricular system may occur in juvenile deer mice exposed to VSNJV-infected black fly bites. In contrast, in intradermally VSNJV-infected juvenile deer mice, viral antigen was widespread in many regions in the brain and also in the heart. ${ }^{2}$ In this case, viral dissemination was attributed to hematogenous infection. ${ }^{2}$

Unlike juvenile mice, all nestling mice from the present study developed viremia on 1 and 2 DPI after being exposed to VSNJV-infected flies. The lesions in the CNS of nestling mice on 2 DPI were widespread throughout the brain, and VSNJV antigen was detected in a large number of neurons in many regions of brain and spinal cord, as well as in myocardium, striated muscles around the spinal column, tongue, lungs, olfactory epithelium, brown fat, and skin. Although the sensory pathway was also involved, viremia associated with widespread viral antigen in many organs, including the CNS, suggests that VSNJV spreads by a hematogenous route in nestling mice, which differed from the infection in juvenile mice.

The pathogenesis of VSNJV, when inoculated intradermally in a previous study, was similar between juvenile and nestling mice, with both age classes developing viremia. ${ }^{2}$ This could be attributed to the amount of inoculum, which is most likely higher in intradermal inoculation compared with fly bite. However, in nestling mice of the present study, virus dissemination was more widespread and prominent compared with intradermally inoculated nestlings. ${ }^{2}$ Since delivery of VSNJV by mosquitoes has been shown to induce a neutralizing antibody response more efficiently than injection, ${ }^{5}$ it is possible that specific factors of the vector are important for infection of deer mice with VSNJV from blood-feeding flies. A previous study has shown that specific factors of the vector may play an important role in VSNJV transmission to rodents by bloodfeeding flies. ${ }^{10}$

Following intranasal VSNJV inoculation of juvenile deer mice, virus travels through the olfactory nerves to the olfactory bulb and subsequently to other parts of the brain. ${ }^{2}$ In juvenile mice inoculated intranasally in the current study, lesions and viral antigen were found primarily in the olfactory epithelium and were similar to those described previously. ${ }^{2}$

The presence of virus in the serum of intranasally infected juvenile deer mice in this study is consistent with previous experimental infections using intranasal inoculation. ${ }^{2}$ However, because intranasal infection is not likely a naturally occurring mode of transmission, this may not reflect the pathogenesis of the natural disease. In addition, the inability to recover virus from naive flies that fed on these viremic juveniles suggests that the virus titers in these mice were not sufficient to infect blood-feeding flies. Although undetectable immediately after feeding, virus may have replicated to detectable and infective levels during the extrinsic incubation period. Unlike the intranasally infected juveniles, no juvenile mice exposed to VSNJV-infected fly bite (group 2) developed detectable viremia. It cannot be excluded that poor feeding by these flies could result in low amounts of viral inoculum resulting in no detectable viremia on 1 and 2 DPI. However, viral antigen was observed in the skin of these juvenile mice, demonstrating that viral transmission occurred in this group.

In contrast to juvenile mice exposed to VSNJV-infected fly bite, all nestling mice developed detectable viremia and, unlike the viremic intranasally infected juveniles, had virus titers sufficient to infect naive flies. The virus titers of nestling mice were generally higher than those of the intranasally infected juvenile mice and may be attributable to specific host factors that allow for enhanced virus transmission and replication in nestling mice following infection by infected insect bite. Thus, the results demonstrate that nestling deer mice have an increased susceptibility to VSNJV infection when inoculated through black fly bite. Similarly, in other rodent species, young mice are more susceptible to VSNJV infection. ${ }^{2,8,13,14,16}$ Based on the titers obtained from nestling mice, it is likely that a minimum of approximately $10^{4} \mathrm{pfu} / \mathrm{ml}$ of virus in the serum of deer mice is necessary for the infection of black flies. It is important to note here that the presence of VSNJV in black fly homogenate indicates transmission only and, for our purposes, was assumed to lead to disseminated infection in at least a portion of these flies, making them capable of transmitting virus. Virus titers in the nestling mice varied proportionately with recovery of virus in flies, indicating that more flies can potentially become infected by feeding on a host with a higher amount of virus in the blood.

In the absence of viremia, such as for the juveniles in the second experiment, transmission was also confirmed by seroconversion. Three juvenile mice developed relatively high neutralizing antibody levels without conspicuous clinical illness. This suggests that juvenile deer mice may be infected with VSNJV without displaying clinical signs and that mice of this age are capable of mounting a sufficient antibody response to limit development of disease and to survive VSNJV infection.

The detection of viremia in nestling mice is the first demonstration of viremia in a host following transmission by VSVNJinfected insect bite. Although previous experimental infections have suggested the potential of deer mice to serve as reservoir or amplifying hosts for VSNJV because of their susceptibility to systemic infection, ${ }^{2,16}$ especially development of relatively high virus titers in serum, these studies used intradermal injection or unnatural routes of infection rather than infection by black fly bites, the natural route of arboviral transmission. In the present study, the development of detectable viremia following infective insect bite satisfies one essential criterion for arboviruses. ${ }^{22}$ Conversely, in this study, the infection of black flies by feeding on viremic nestling mice is the first demonstration of VSNJV infection of an insect by feeding on a viremic host, further fulfilling the definition of an arbovirus. Together, these 2 demonstrations, viremia following VSNJV-infected insect bite and infection of insects via blood feeding on a viremic host, were able to reproduce principal components of what may occur in nature with the enzootic VSNJV transmission cycle. Besides the involvement of a viremic host in VSNJV transmission, a nonviremic host may also exert an important role in VS epidemiology. VSNJV can be transmitted horizontally by black flies to uninfected flies by cofeeding on 
the same nonviremic deer mouse. ${ }^{7}$ In addition, mechanical transmission of VSNJV by black flies has been demonstrated in domestic swine. ${ }^{18}$

In summary, the present study demonstrates that VSNJVinfected black flies were able to transmit the virus to juvenile and nestling mice, which were susceptible to infection developing significant CNS lesions. Naive flies were infected after feeding on viremic nestling deer mice, which could be potential reservoir hosts of VSNJV and may play an important role in the enzootic maintenance of the virus.

\section{Declaration of Conflicting Interests}

The author(s) declared no potential conflicts of interest with respect to the research, authorship, and/or publication of this article.

\section{Funding}

The author(s) disclosed receipt of the following financial support for the research, authorship, and/or publication of this article: The project was supported by the National Research Initiative of the USDA Cooperative State Research, Education and Extension Service, grant number 20013520410069 . Supplemental support was provided through Cooperative Agreement 2002-9613-0032-CA, Veterinary Services, APHIS, USDA. L. P. Mesquita was supported by a doctoral and research internship abroad grant from São Paulo Research Foundation (FAPESP), process no. 2014/20631-8.

\section{References}

1. Comer JA, Tesh RB, Modi GB, et al. Vesicular stomatitis virus, New Jersey serotype: replication in and transmission by Lutzomyia shannoni (Diptera: Psychodidae). Am J Trop Med Hyg. 2003;42:483-490.

2. Cornish TE, Stallknecht DE, Brown CC, et al. Pathogenesis of experimental vesicular stomatitis virus (New Jersey serotype) infection in the deer mouse (Peromyscus maniculatus). Vet Pathol. 2001;38:396-406.

3. Cupp EW, Mare CJ, Cupp MS, et al. Biological transmission of vesicular stomatitis virus (New Jersey) by Simulium vittatum (Diptera: Simuliidae). J Med Entomol. 1992;29:137-140.

4. De Lahunta A, Glass E. Veterinary Neuroanatomy and Clinical Neurology. St Louis, MO: Elsevier; 2009.

5. Limesand KII, Higgs S, Pearson LD, et al. Potentiation of vesicular stomatitis New Jersey virus infection in mice by mosquito saliva. Parasite Immunol. 2000; 22:461-467.

6. Mead DG, Mare CJ, Cupp EW. Vector competence of select black fly species for vesicular stomatitis virus (New Jersey serotype). Am J Trop Med Hyg. 1997; 57:42-48
7. Mead DG, Ramberg FB, Besselsen DG, et al. Transmission of vesicular stomatitis virus from infected to noninfected black flies co-feeding on nonviremic deer mice. Science. 2000;287:485-487.

8. Murphy FA, Harrison AK, Bauer SP. Experimental vesicular stomatitis virus infection: ultrastructural pathology. Exp Mol Pathol. 1975;23:426 440.

. National Veterinary Services Laboratories. Serologic Microtitration Techniques. Ames, IA: USDA, APHIS; 1981.

10. Perez de Leon AA, O'Toole D, Tabachnick WJ. Infection of guinea pigs with vesicular stomatitis New Jersey virus transmitted by Culicoides sonorensis (Diptera: Ceratopogonidae). J Med Entomol. 2006;43:568-573.

11. Rodriguez LL. Emergence and re-emergence of vesicular stomatitis in the United States. Virus Res. 2002;85:211-219.

12. Rodriguez LL, Letchworth GJ, Spiropoulou CF, et al. Rapid detection of vesicular stomatitis virus New Jersey serotype in clinical samples by using polymerase chain reaction. J Clin Microbiol. 1993;31:2016-2020.

13. Sabin AB, Olitsky PK. Influence of host factors on the neuroinvasiveness of vesicular stomatitis virus, I. effect of age on the invasion of the brain by virus instilled in the nose. $J$ Exp Med. 1937;66:15-34.

14. Sabin AB, Olitsky PK. Influence of host factors on neuroinvasiveness of vesicular stomatitis virus, II: effect of age on the invasion of the peripheral and central nervous systems by virus injected into the leg muscles or the eye. $J$ Exp Med. 1937;66:35-57.

15. Tesh RB, Chaniotis BN, Johnson KM. Vesicular stomatitis virus, Indian serotype: multiplication in and transmission by experimentally infected phlebotomine sandflies (Lutzomyia trapidoi). Am J Epidemiol. 1971;93: 491-495.

16. Tesh RB, Peralta PH, Johnson KM. Ecologic studies of vesicular stomatitis virus, II: results of experimental infection in Panamanian wild animals. $A m J$ Epidemiol. 1970;91:216 224

17. Webb PA, McLean RG, Smith GC, et al. Epizootic vesicular stomatitis in Colorado, 1982: some observations on the possible role of wildlife populations in an enzootic maintenance cycle. J Wildl Dis. 1987;23:192-198.

18. Smith PF, Howerth EW, Carter D, et al. Mechanical transmission of vesicular stomatitis New Jersey virus by Simulium vittatum (Diptera: Simuliidae) to domestic swine (Sus scrofa). J Med Entomol. 2009;46:1537-1540.

19. Mead DG, Lovett KR, Murphy MD, et al. Experimental transmission of vesicular stomatitis New Jersey virus from Simulium vittatum to cattle: clinical outcome is influenced by site of insect feeding. $J$ Med Entomol. 2009;46: 866-872.

20. Reis JL Jr, Rodriguez LL, Mead DG, et al. Lesion development and replication kinetics during early infection in cattle inoculated with vesicular stomatitis New Jersey virus via scarification and black fly (Simulium vittatum) bite. Vet Pathol. 2011;48:547-557.

21. World Health Organization. Arthropod-borne and rodent-borne viral diseases. World Health Organ Tech Rep Ser. 1985;719:36.

22. World Iealth Organization. Arboviruses and human disease. World Health Organ Tech Rep Ser. 1967;369:9. 
Avaliação da Resposta Imune e Inflamatória no Sistema Nervoso Central de Camundongos Infectados pelo Herpesvírus Bovino tipo 5 (BoHV-5) 


\section{AVALIAÇÃO DA RESPOSTA IMUNE E INFLAMATÓRIA NO SISTEMA NERVOSO CENTRAL DE CAMUNDONGOS INFECTADOS PELO HERPESVÍRUS BOVINO TIPO 5 (BOHV-5)}

No presente capítulo é apresentado um artigo que será submetido ao periódico Virology.

\section{RESUMO}

O herpesvírus bovino tipo 5 (BoHV-5) é responsável por causar meningo-encefalite em bovinos jovens, principalmente naqueles imunossuprimidos. Inicialmente, o BoHV-5 infecta células epiteliais da mucosa nasal e células neurônios olfatórios receptores infectando desta maneira o sistema nervoso central (SNC) e estabelecendo latência no gânglio trigeminal. Poucos estudos foram conduzidos para elucidar a resposta imune durante a infecção pelo BoHV-5. Apesar de existirem evidências da infecção pelo BoHV-5 em camundongos imunodeficientes, pouco se sabe a respeito da replicação viral, resposta imune e evolução da infecção pelo BoHV-5 no SNC de camundongos com o sistema imune intacto. Portanto, o presente estudo teve como objetivo avaliar a resposta do SNC à infecção pelo BoHV-5 em camundongos isogênicos BALB/c em diferentes dias pós-inoculação (DPI). O BoHV-5 quando inoculado pela via intracraniana foi capaz de infectar e se replicar no SNC de camundongos BALB/c. Entretanto, até o momento avaliado (15 DPI), os animais sobreviveram a infecção sem apresentar sinais neurológicos evidentes. A infecção foi acompanhada de uma resposta imune do tipo Th1 importante, com expressão significativa das citocinas IFN-ץ e TNF- $\alpha$, e quimiocina CCL-2. A expressão das citocinas e quimiocinas se deu principalmente no início da infecção (3 e 4 DPI), a qual foi seguida por uma meningo-encefalite com manguitos perivasculares e periventriculite, compostas predominantemente por macrófagos e linfócitos. Após a expressão significativa das citocinas e quimiocina, os animais foram capazes de debelar a infecção aguda, uma vez que partículas virais viáveis não foram detectadas após o 6 DPI. Entretanto, o BoHV-5 foi capaz de infectar o 
gânglio trigeminal, uma vez que grande quantidade de DNA de BoHV-5 foi detectada no 3 DPI, o que foi confirmado pela presença de antígenos virais no citoplasma de neurônios do gânglio trigeminal de camundongos BALB/c infectados.

\section{ABSTRACT}

The bovine herpesvirus type 5 (BoHV-5) is responsible for causing meningoencephalitis in young cattle, mainly on those with immunosuppression. Initially, BoHV-5 infects epithelial cells and olfactory receptor neurons within the nasal cavity and travels to the central nervous system (CNS), where it can stablish a latent infection in trigeminal ganglia. Few studies have attempted to study the immune response during BoHV-5 infection. Despite that BoHV-5 can infect mice with severe genetic immune deficiencies, little is known about viral replication, immune response and the course of the disease in the CNS of wild-type mice. Therefore, the aim of this study was to evaluate the response in the CNS of isogenic BALB/c mice to BoHV-5 infection in different days post-inoculation (DPI). BoHV-5, when inoculated through intracranial route, was able to infect and replicate within the CNS of BALB/C mice. However, until the evaluated time (15 DPI), the mice was able to survive without showing prominent neurological signs. The infection was accompanied by an important Th1 immune response, with a significant expression of the cytokines IFN-Y and TNF- $\alpha$, and chemokine CCL-2. The expression of these cytokines and chemokines was detected mainly on the early course of infection ( 3 and $4 \mathrm{DPI}$ ), and it was followed by a meningoencephalitis with perivascular cuffing and periventriculitis, composed mainly by macrophages and lymphocytes. After the expression of cytokines and chemokine, the mice were able to curb BoHV-5 acute infection, since viable viral particles were not detected after 6 DPI. However, BoHV-5 was able to infect the trigeminal ganglia, since a large number of BoHV-5 DNA copies was detected on $3 \mathrm{DPI}$, which was confirmed by the presence of viral antigens within the cytoplasm of neurons in the trigeminal ganglia of infected BALB/c mice. 


\subsection{INTRODUÇÃO}

O herpesvírus bovino tipo 5 (BoHV-5) pertence à família Herpesviridae, e é responsável por causar meningo-encefalite em bovinos jovens e é antigenicamente e geneticamente relacionado ao herpesvírus bovino tipo 1 (BoHV-1). Embora seja antigenicamente e geneticamente relacionado ao BoHV-1, o BoHV-5 possui uma capacidade de neuro-invasão e neurovirulência bem superior. Após uma replicação inicial no epitélio nasal, o BoHV-5 infecta células olfatórias e terminações nervosas do nervo maxilar, e se dissemina para o sistema nervoso central (SNC) por meio dos nervos olfatório ou trigêmio (DEL MÉDICO ZAJAC et al., 2010). Em bovinos, pode ocorrer uma reativação viral a partir do gânglio trigeminal em situações de imunossupressão (PEREZ et al., 2002). Desta forma, o animal pode desenvolver a doença clínica caracterizada por sinais neurológicos acentuados (PEREZ et al., 2002). As lesões no SNC causadas pelo BoHV-5 são caracterizadas por uma meningo-encefalite necrotizante que afeta principalmente os lobos frontal, temporal e parietal do telencéfalo, que macroscopicamente se caracteriza por amolecimento (malácia) do tecido nervoso com achatamento dos giros e hemorragia (RISSI; BARROS, 2013). Microscopicamente, estas lesões são caracterizadas por uma meningo-encefalite necrotizante, com áreas de astrogliose e necrose neuronal laminar, com ocasionais inclusões intranucleares eosinofílicas em astrócitos e neurônios (RISSI; BARROS, 2013).

Poucos estudos foram conduzidos para elucidar a resposta imune após a infecção pelo BoHV-5 (DEL MÉDICO ZAJAC et al., 2010). A doença aguda causada pelo BoHV-5 tem sido reproduzida em coelhos (BELTRÃO et al., 2000), o que de certa forma ajudou a entender as formas de latência e reativação viral. Em camundongos, quando inoculado pela via intraperitoneal, o BoHV-5 é capaz de se disseminar nos animais infectados, e a infecção em camundongos wild-type assim como naqueles com deficiências genéticas combinadas no sistema imune inato ou adaptativo revelaram novos conhecimentos a respeito da patogênese do BoHV-5 (ABRIL et al., 2004). Entretanto, a infecção pelo vírus nestes animais foi demonstrada apenas pela presença de DNA viral por PCR quantitativo (qPCR) e produção de anticorpos (ABRIL et al., 2004). Neste mesmo estudo, não foi possível avaliar a presença de partículas virais viáveis no tecido em decorrência de baixos títulos virais. O sistema interferon (IFN)- $\mathrm{y}$ intacto foi responsável pela eficiente 
replicação do BoHV-5 em neurônios e contribui para o desenvolvimento da doença neurológica (ABRIL et al., 2004). Estudos anteriores com isolados nacionais do BoHV-5, inoculados pela via intranasal, não conseguiram induzir encefalite em camundongos, no entanto a idade e a linhagens destes animais são fundamentais para o sucesso de indução da encefalite (SILVA et al., 1999; BELTRÃO et al., 2000; MORI et al., 2012). Estudos prévios em nosso laboratório, demonstraram que o BoHV-5, mesmo em altos títulos virais, não foi capaz de induzir encefalite, ou mesmo evidências de invasão do SNC de camundongos BALB/c wild type quando inoculado pela via intranasal (P. C. Maiorka, dados não publicados).

Apesar de existirem evidências de que o BoHV-5 em camundongos com deficiências genéticas combinadas, quando inoculado pela via intraperitoneal pode afetar o SNC (ABRIL et al., 2004), ainda não há evidências concretas de replicação viral, indução de encefalite e/ou latência no gânglio trigeminal. Portanto, o presente estudo tem como objetivo avaliar a resposta imune do SNC frente a infecção pelo BoHV-5 em camundongos isogênicos BALB/c inoculados pela via intracraniana, bem como avaliar a capacidade de replicação viral, neuropatogenicidade e latência em gânglio trigeminal.

\subsection{MATERIAIS E MÉTODOS}

\subsubsection{Herpesvírus bovino tipo 5 (BoHV-5)}

A amostra do BoHV-5 foi gentilmente cedida pela Profa. Dra. Edviges Maristela Pituco (Laboratório de Viroses de Bovídeos - Instituto Biológico de São Paulo - São Paulo). O vírus foi multiplicado e quantificado no Instituto Biológico de São Paulo, em microplacas utilizando-se células da linhagem MDBK (Mardin-Darby bovine kidney epithelial cells - CCL-22, ATCC) livres de contaminação pelo vírus da diarreia viral bovina (BVDV) e por Mycoplasma spp. As células foram cultivadas em meio essencial de Eagle (EMEM) acrescido de 10\% de soro fetal bovino, incubadas a $37^{\circ} \mathrm{C}$ em câmara úmida com atmosfera de $5 \%$ de $\mathrm{CO}_{2}$. Para obtenção do vírus, as células foram congeladas a $-80^{\circ} \mathrm{C}$ e posteriormente foram submetidas a 
centrifugação a $12.000 \mathrm{rpm}$ por 15 minutos a $4^{\circ} \mathrm{C}$. As alíquotas de vírus foram armazenadas a $-80^{\circ} \mathrm{C}$, e descongeladas apenas no momento de sua utilização. $\mathrm{O}$ título viral foi obtido em microplaca segundo método descrito por Reed e Müench (1938) para o cálculo da $\operatorname{TCID}_{50 / \mathrm{ml}}$ (dose infectante $50 \%$ em cultura de tecidos). A estirpe viral de BoHV-5 utilizada foi submetida a 3 passagens in vitro.

\subsubsection{Camundongos e delineamento experimental}

Foram utilizadas 200 fêmeas, com três semanas de idade, da linhagem BALB/c $\left(H 2^{d}\right)$. Os animais foram obtidos do biotério do Departamento de Patologia, da Faculdade de Medicina Veterinária e Zootecnia, USP. O ambiente onde os animais permaneceram durante todo 0 experimento possuía temperatura controlada entre 22 e $24^{\circ} \mathrm{C}$, umidade relativa do ar entre 40 e $60 \%$ e fotoperíodo de 12 horas de claro e 12 horas de escuro. Os grupos foram acondicionados

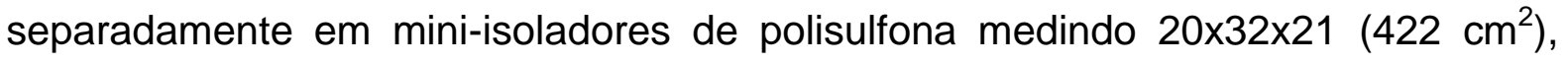
nos quais a cama foi formada por maravalha de pinnus autoclavada. Ração comercial para camundongos (Nuvilab CR1, Nuvital Nutrientes) e água filtrada e autoclavada foram fornecidas ad libitum durante todo o experimento. Todas as condições ambientais e manejo dos animais estão de acordo com aquelas previstas pelo National Research Council (NCR 2010). Todos os procedimentos aqui descritos foram aprovados pela Comissão de Ética no Uso de Animais (CEUA) da Faculdade de Medicina Veterinária e Zootecnia (FMVZ), Universidade de São Paulo (USP) sob o número de protocolo CEUA 3485200814.

Os 100 camundongos do grupo experimental foram inoculados por via intracraniana (hemisfério cerebral esquerdo), sob anestesia inalatória com sevoflurano, com $20 \mu \mathrm{l}$ de meio essencial de Eagle (EMEM) contendo a suspensão do BoHV-5, cultivado em células MDBK. Os 100 camundongos do grupo controle foram tratados de forma idêntica aos experimentais e receberam $20 \mu$ de meio EMEM extraído de cultivo de células MDBK similarmente ao utilizado na suspensão viral, por via intracraniana. Os animais foram observados e avaliados duas vezes ao dia, no intuito de verificar possíveis sinais clínicos por até 15 dias pós inoculação (DPI). Os grupos, tanto experimental como controle, foram divididos de acordo com 
o dia da eutanásia e coleta de amostras. Os camundongos inoculados com o BoHV-5 foram eutanasiados e as amostras de SNC foram coletadas em diferentes DPI (Tabela 1). A coleta de material para a análise histopatológica/imunohistoquímica, isolamento viral, e expressão gênica de citocinas e quimiocina se deu no $3,4,5,6,7,8,10$ e $15 \mathrm{DPI}$, tanto no grupo experimental como no grupo controle, ao passo que para quantificação da carga viral no SNC e gânglio trigeminal foi realizada no 1, 2 e 3 DPI. Para a análise de expressão gênica de citocinas e quimiocina pró-inflamatória, mensuração da carga viral no SNC e gânglio trigeminal, e exame histopatológico/imuno-histoquímico foram utilizados quatro camundongos BALB/c para cada DPI. Para a análise de isolamento viral foram utilizados três camundongos BALB/c para cada DPI (Tabela 1).

Tabela 1 - Delineamento experimental contendo os grupos de camundongos BALB/c inoculados por via intracraniana com o BoHV-5

\begin{tabular}{c|c|c|c}
\hline \multirow{2}{*}{$\begin{array}{c}\text { Dias pós } \\
\text { inoculação (DPI) }\end{array}$} & \multicolumn{3}{|c}{ Número de camundongos utilizados nos testes laboratoriais } \\
\cline { 2 - 4 } & $\begin{array}{c}\text { Histopatologia/IHQ } \\
\text { e expressão gênica }\end{array}$ & Carga viral & Isolamento viral \\
\hline 1 & - & 4 & - \\
2 & - & 4 & - \\
3 & 4 & 4 & 3 \\
4 & 4 & - & 3 \\
5 & 4 & - & 3 \\
6 & 4 & - & 3 \\
7 & 4 & - & 3 \\
8 & 4 & - & 3 \\
10 & 4 & - & 3 \\
15 & 4 & - & 3 \\
\hline
\end{tabular}




\subsubsection{Necropsia, coleta de material e perfusão transcardíaca}

Para uma adequada preservação dos tecidos, principalmente do SNC, realizou-se a perfusão transcardíaca em quatro animais de cada grupo para análise histológica/imuno-histoquímica. Para a realização do procedimento foi utilizada uma bomba peristáltica para camundongos com velocidade regulável (MasterFlex-ColeParmer $^{\circledR}$ ). Os animais foram anestesiados pela administração intraperitoneal de uma solução anestésica contendo $20 \mathrm{mg} / \mathrm{Kg}$ de xilazina e $100 \mathrm{mg} / \mathrm{Kg}$ de quetamina. Após uma adequada anestesia, na qual havia ausência dos reflexos podal e ocular, realizou-se a abertura da cavidade torácica. Uma agulha (26G), de ponta romba, conectada ao sistema de perfusão, foi introduzida no ventrículo esquerdo, e após o início da perfusão, realizou-se um corte no átrio direito, para que ocorresse a drenagem do sangue. Inicialmente procedeu-se à perfusão com aproximadamente $40 \mathrm{~mL}$ de solução de $0,9 \%$ de $\mathrm{NaCl}$ contendo EDTA tamponada $(\mathrm{pH} 7,4)$ seguida de perfusão com formalina tamponada a $10 \%$ até serem observados sinais de fixação dos órgãos internos. Amostras de SNC foram armazenadas em formalina tamponada $10 \%$ por $24 \mathrm{~h}$ até 0 momento do processamento para análise histopatológica.

Nos demais camundongos realizou-se a eutanásia por overdose de anestésico isoflurano para análise de GPCR para quantificação de citocinas e quimiocina pró-inflamatória, isolamento viral e qPCR absoluta para quantificação viral. Após a eutanásia, os mesmos foram necropsiados, e o SNC foi coletado e congelado imediatamente a $-80^{\circ} \mathrm{C}$.

\subsubsection{Análise histológica e imuno-histoquímica (IHQ)}

As amostras de SNC coletadas durante a necropsia dos camundongos e fixadas em formalina tamponada a $10 \%$ foram processadas pelos métodos rotineiros de histologia. As amostras foram desidratadas em concentrações crescentes de álcool etílico, diafanizadas em xilol e incluídas em parafina. Cortes de $5 \mu \mathrm{m}$ foram 
desparafinados em xilol e reidratados em concentrações decrescentes de álcool etílico. Posteriormente as lâminas foram coradas por hematoxilina e eosina (HE).

$\mathrm{Na}$ análise histológica e imuno-histoquímica, nas secções coronais do SNC, as seguintes estruturas foram avaliadas: bulbo olfatório, córtex piriforme, septoestriada, diencéfalo rostral, diencéfalo caudal, mesencéfalo rostral, cerebelo rostral, cerebelo caudal e início da medula espinhal.

A análise de $\mathrm{IHQ}$ foi realizada no SNC de quatro camundongos no $3,4,5,6$, 7, 8, 10 e 15 DPI. Cortes de $5 \mu \mathrm{m}$ do SNC em lâminas silanizadas Starfrost $\left(\right.$ Knitte $\left.^{\circledR}\right)$, desparafinados em xilol e reidratados foram submetidos à análise IHQ para detecção de antígenos de BoHV-5. Esta foi realizada utilizando-se a técnica de biotina-estreptavidina-peroxidase, semelhantemente ao descrito por Hübner et al. (2005). Os cortes histológicos foram submetidos ao bloqueio da peroxidase endógena com peróxido de hidrogênio a $3 \%$ em metanol por 30 minutos. Os antígenos do BoHV-5 foram recuperados por meio de digestão enzimática com proteinase K (GE Healthcare ${ }^{\circledR}$ ) a $0,05 \%$ por 15 minutos a $37^{\circ} \mathrm{C}$. Para o bloqueio de reações inespecíficas, os cortes foram submergidos em solução de leite desnatado (Molico, Nestlé ${ }^{\circledR}$ ) diluído em PBS a 5\% por uma hora. As lâminas foram incubadas por 14 a 16 horas overnight com anticorpo primário monoclonal clone 4E4 antiBoHV-5 (produzido e gentilmente cedido pelo professor Rudi Weiblen, Setor de Virologia, Universidade de Santa Maria- RS) na diluição de 1:50. Anticorpos secundários biotinilados (Dako, Carpinteria, CA) foram aplicados, seguidos pelo complexo avidina-biotina peroxidase (Dako), ambos por 30 minutos na temperatura ambiente. Posteriormente as lâminas foram submetidas ao cromógeno Vector Red (Vector NovaRed $^{\circledR}$ ), conforme as instruções do fabricante, e posteriormente contra coradas com hematoxilina. Secções de córtex cerebral de bovinos com meningoencefalite necrotizante por BoHV-5 foram utilizadas como controles positivos. Como controles negativos os anticorpos primários foram substituídos por soros homólogos não imunes. Os cortes foram considerados positivos para o antígeno de BoHV-5 quando havia intensa marcação em células inflamatórias, células da glia e neurônios. 


\subsubsection{Extração do RNA, transcrição reversa para síntese do DNA complementar (cDNA) e qPCR para quantificação de citocinas e quimiocina pró-inflamatórias}

A expressão gênica das citocinas pró-inflamatórias (IL-6, IFN-y e TNF- $\alpha$ ), e da quimiocina (CCL-2) no SNC dos camundongos infectados, no 3, 4, 5, 6, 7, 8, 10 e $15 \mathrm{DPI}$, foi realizada por transcrição reversa seguida pela reação de PCR quantitativa em tempo real (RT-qPCR) em triplicata e placas com 96 poços no aparelho StepOne Plus (Applied Biosystems). A extração de RNA de aproximadamente $30 \mathrm{mg}$ das amostras de SNC coletadas a partir do local de inoculação em quatro camundongos no 3, 4, 5, 6, 7, 8, 10 e 15 DPI foi realizada com o RNAspin Mini RNA isolation Kit (GE), de acordo com as recomendações do fabricante. Para eliminar o DNA residual, as amostras de RNA extraídas foram tratadas com DNAse I (RNAse free) (Invitrogen) e armazenadas em microtubos de polipropileno de $1,5 \mathrm{~mL}$ em freezer a $-80^{\circ} \mathrm{C}$ até $\mathrm{O}$ processamento. A quantificação de RNA foi realizada em espectrofotômetro NanoDrop ${ }^{\circledR} 2000$ (Thermo Fisher Scientific, Inc.). As amostras que apresentarem razão da absorbância 280/260 nm entre 1.9 - 2.1 foram consideradas adequadas para transcrição reversa. A síntese do DNA complementar (cDNA) foi realizada por meio de reação com transcriptase reversa a partir do RNA isolado, utilizando kit comercial Super Script ${ }^{\circledR}$ VILOTM cDNA Synthesis (Life Technologies, Califórnia, E.U.A). O cDNA foi diluído para $0,5 \mu \mathrm{g} / \mathrm{ml}$ após ser quantificado em Qubit® 2.0 Fluorometer (Qubit $\AA$ dsDNA BR).

Para a avaliação da expressão gênica das citocinas e quimiocina por PCR quantitativo (qPCR) em tempo real, as reações foram preparadas utilizando o conjunto de reagentes TaqMan ${ }^{\circledR}$ Universal PCR Master Mix (Applied Biosystems) em triplicata utilizando-se StepOnePlus ${ }^{\mathrm{TM}}$ (Applied Biosystems). Iniciadores e sondas de hidrólise $\operatorname{TaqMan}^{\circledR}$ tipo MGB marcadas com o fluoróforo FAM na posição reporter (Applied Biosystems) para IL-6 (Mm00446190_m1), IFN- $\gamma$ (Mm01168134_m1), TNF-a (Mm00443258_m1) e CCL2 (Mm00441242_m1) foram utilizados. A sonda TaqMan $^{\circledR}$ tipo MGB marcada com fluoróforo VIC na posição reporter para o gene 18S rRNA (RNA ribossomal) (Hs99999901_s1) foi utilizada como controle endógeno para a quantificação relativa do mRNA em cada amostra. 
A reação foi realizada em um volume final de $20 \mu \mathrm{L}$ contendo $10 \mu \mathrm{L}$ do tampão TaqMan Universal Master Mix 2× (Applied Biosystems), $1 \mu \mathrm{L}$ (0,5 ng) de cDNA total, $1 \mu \mathrm{L}$ do Assay Mix (0,9 mM de cada iniciador e 0,25 mM da sonda TaqMan MGB ${ }^{\mathrm{TM}}$ ) e água ultra-pura q.s.p. A reação se deu nas seguintes condições: ativação a $50^{\circ} \mathrm{C}$ por 2 min e desnaturação inicial a $95^{\circ} \mathrm{C}$ durante 10 min seguido de 40 ciclos com 15 $\mathrm{s}$, a $95^{\circ} \mathrm{C}$ para desnaturação e $1 \mathrm{~min}$ a $60^{\circ} \mathrm{C}$ para anelamento e extensão. A quantificação relativa da expressão de citocinas pró-inflamatórias (IL-6, IFN-ү e TNF- $\alpha$ ) e quimiocina (CCL-2) em relação ao controle endógeno $18 \mathrm{~S}$ foi calculada pelo método comparativo $\mathrm{Ct}$, conforme Steibel et al. (2009).

\subsubsection{Isolamento viral}

No intuito de verificar a presença de partículas virais viáveis nos tecidos, o isolamento viral foi realizado no SNC dos animais no 3, 4, 6, 7, 8, 10 e 15 DPI. Os órgãos íntegros foram descongelados, macerados e diluídos com EMEM na proporção de $33 \%$ peso/volume. Após a centrifugação a $500 \mathrm{~g}$ por $10 \mathrm{~min}$ a $4^{\circ} \mathrm{C}$ dos macerados diluídos, os sobrenadantes foram recolhidos, e $100 \mu \mathrm{L}$ dos mesmos foram inoculados em microplacas de 48 poços contendo monocamadas de células MDBK, as quais foram incubadas a $37^{\circ} \mathrm{C}$ por uma hora em câmara úmida contendo atmosfera a $5 \%$ de $\mathrm{CO}_{2}$. Após a adsorção viral nas monocamadas de células, as mesmas foram lavadas com EMEM, e incubadas com $500 \mu \mathrm{L}$ de EMEM contendo $2 \%$ de soro fetal bovino, a $37^{\circ} \mathrm{C}$ em câmara úmida contendo atmosfera a $5 \%$ de $\mathrm{CO}_{2}$. Os cultivos celulares foram avaliados por sete dias consecutivos para a observação de possíveis efeitos citopáticos (ECP) de herpesvírus, os quais podem ser caracterizados por desprendimento celular, aumento da refração, formação de células gigantes e sincícios celulares. Nos casos em que não se observaram ECPs na primeira passagem, duas passagens adicionais foram realizadas semelhantemente ao descrito anteriormente. Para tal, a microplaca da primeira passagem foi congelada a $-80^{\circ} \mathrm{C}$ para causar rompimento das membranas celulares, e após o descongelamento, as amostras foram centrifugadas a $500 \mathrm{~g}$ por $10 \mathrm{~min}$ a $4^{\circ} \mathrm{C}$, e $100 \mu \mathrm{L}$ do sobrenadante resultante foi utilizado para a passagem seguinte. 
Nos órgãos em que não se observaram ECPs nas três passagens realizadas foram considerados negativos na prova de isolamento viral.

\subsubsection{Detecção do BoHV-5 pela PCR quantitativa (qPCR) absoluta em tempo real}

Inicialmente, para padronização da qPCR absoluta para quantificação da carga viral no SNC de camundongos infectados pelo BoHV-5 foi realizada uma PCR convencional a partir do DNA extraído do isolado viral e do próprio SNC dos camundongos infectados. Os primers e sondas utilizados na qPCR foram descritos previamente (Quadro 1) (DIALLO; CORNEY; RODWELL, 2011). Para a realização da PCR convencional, o DNA genômico foi extraído das amostras de encéfalo e isolado viral utilizando-se o kit Reagentes Illustra células e tecidos (GE), seguindo o protocolo determinado pelo fabricante. As amostras de DNA extraídas e quantificadas em espectrofotômetro NanoDrop ${ }^{\circledR} 2000$ (Thermo Fisher Scientific, Inc.), foram armazenadas em microtubos de polipropileno de 1,5 $\mathrm{mL}$ em freezer a $-80^{\circ} \mathrm{C}$.

A PCR convencional foi realizada em uma reação contendo $2 \mu$ de DNA extraído e $23 \mu \mathrm{l}$ do mix de PCR contendo: 0,5 $\mu \mathrm{M}$ de cada um dos primers senso e antisenso (Tabela 2), 2,5 $\mu \mathrm{L}$ de tampão 10X, $4 \mu \mathrm{L}$ de dNTPs 1,25 mM, 37,5 mM de $\mathrm{MgCl}_{2}$ e 1,0 U de TaqDNA polimerase Platinum (Invitrogen ${ }^{\mathrm{TM}}$ Life Technologies, USA). A reação de amplificação foi realizada nas seguintes condições: desnaturação a $95^{\circ} \mathrm{C}$ por $5 \mathrm{~min}$; seguido de 30 ciclos de $95^{\circ} \mathrm{C}$ por $30 \mathrm{~s}, 5^{\circ} \mathrm{C}$ por $30,72^{\circ} \mathrm{C}$ por $30 \mathrm{~s}$ e uma extensão final de $72^{\circ} \mathrm{C}$ por $5 \mathrm{~min}$. Os produtos amplificados foram analisados pela eletroforese em gel de agarose a 1,5\% em tampão TBE pH 8,4 (89 mM Tris; 89 $\mathrm{mM}$ de ácido bórico; 2 mM EDTA) em uma voltagem constante (80V) por aproximadamente $1 \mathrm{~h}$, e posteriormente corado com Sybr Safe (Invitrogen, Life Technologies), e visualizado por meio de luz ultravioleta. 
Quadro 1 - Sequência de primers e sonda da qPCR para detecção de BoHV-5

\begin{tabular}{|c|c|c|}
\hline $\begin{array}{c}\text { Nome do primer e } \\
\text { sonda }\end{array}$ & $\begin{array}{c}\text { Sequência e localização no } \\
\text { genoma }(\mathrm{pb})\end{array}$ & $\begin{array}{l}\text { Gene e tamanho do } \\
\text { fragmento }\end{array}$ \\
\hline BoHV-5 F & $\begin{array}{c}5^{\prime} \\
\text { GGTACTTCTTCTTGGTGATG } \\
\text { 3' } \\
47302-47321\end{array}$ & \\
\hline BoHV-5 R & $\begin{array}{c}\text { 5' TCGGTCTTCGTCAAGTTC } \\
\text { 3' } \\
47444-47461\end{array}$ & $\begin{array}{l}\text { UL30 } \\
160 \mathrm{pb}\end{array}$ \\
\hline BoHV-5 sonda & $\begin{array}{c}\text { 5' VIC }^{\prime} \\
\text { AGGTCTTCTCGCACTC - } \\
\text { MGB 3' } \\
47338-47353\end{array}$ & \\
\hline
\end{tabular}

Fonte: (MESQUITA, L. P., 2016)

Para o desenvolvimento e padronização de uma reação de qPCR em tempo real para quantificação absoluta do BoHV-5 no SNC, os produtos gerados da amplificação na PCR convencional descrita acima foram inseridos individualmente em um vetor Pcr 2.1 TOPO (Invitrogen, Life Technologies), transformados e clonados em células competentes $E$. coli TOP10 conforme as recomendações do fabricante. O DNA plasmideal resultante da clonagem em células $E$. coli foi extraído por meio do PureLink Quick Plasmid Miniprep Kit (Invitrogen, Life Technologies) e quantificado no NanoDrop 2000 Spectrophotometer (Thermo Scientific). Após a quantificação, a relação entre a massa e número de plasmídeos foi calculada por meio da ferramenta online: http://www.thermofisher.com/br/en/home/brands/thermoscientific/molecular-biology/molecular-biology-learning-center/molecular-biology-reso urce-library/thermo-scientific-web-tools/dna-copy-number-calculator.html, com 0 objetivo de obter uma concentração inicial de $10^{10}$ cópias do plasmídeo. A partir desta concentração inicial, diluições seriadas na base 10 foram realizadas a fim de se construir a curva padrão e determinar a sensibilidade analítica do teste. Para tal, foi utilizada a plataforma StepOne Plus (Applied Biosystems) com o seguinte protocolo de ciclagem para amplificação: um ciclo de um ciclo de $95^{\circ} \mathrm{C}$ durante 10 
min; 40 ciclos de $95^{\circ} \mathrm{C}$ durante $15 \mathrm{~s}$ e $60^{\circ} \mathrm{C}$ durante $1 \mathrm{~min}$, ocorrendo a leitura da fluorescência neste último passo durante a fase de "anelamento" e extensão. As reações de qPCR foram realizadas com um volume final de $25 \mu \mathrm{L}$, contendo $12,5 \mu \mathrm{L}$ de Taqman Master Mix (Applied Biosystems), 0,5 $\mu \mathrm{M}$ de cada primer (senso e antisenso), 0,025 $\mu \mathrm{L}$ da sonda BoHV-5, $1 \mu \mathrm{L}$ de DNA e água livre de nucleases para finalizar com um volume de $25 \mu \mathrm{L}$. Na curva padrão, foram utilizados seis pontos (diluições), em duplicata: $10^{7}, 10^{6}, 10^{5}, 10^{4}, 10^{3}$ e $10^{2}$ cópias do DNA plasmideal contendo inserto do gene UL30 do BoHV-5.

\subsubsection{Extração de DNA para posterior detecção do BoHV-5 pela PCR quantitativa (qPCR) em tempo real}

Para a extração do DNA genômico das amostras de SNC e gânglio trigeminal foram utilizadas amostras provenientes de quatro camundongos de cada grupo experimental infectados pelo BoHV-5 e grupo controle no 1, 2, e 3 DPI. Para tal, o SNC foi macerado em microtubos de $2 \mathrm{~mL}$ contendo $800 \mu \mathrm{L}$ de PBS. O gânglio trigeminal foi macerado em microtubos contendo $200 \mu \mathrm{L}$ de PBS. Os microtubos foram inseridos em aparelho para maceração de tecidos (Tissue Lyser LT, Qiagen) por 5 min. Após a maceração, as amostras de SNC foram centrifugadas a $12000 \mathrm{~g}$ por $15 \mathrm{~min}$ e $200 \mu \mathrm{L}$ do sobrenadante foi utilizado para se realizar a extração de DNA. O DNA foi extraído com o método fenol/clorofórmio. Resumidamente, em $200 \mu \mathrm{L}$ do sobrenadante do SNC e da solução contendo o gânglio trigeminal macerado, foram adicionados $100 \mu \mathrm{L}$ de clorofórmio, seguidos por agitação em vórtex e centrifugação a $12000 \mathrm{~g}$ por $5 \mathrm{~min}$. O sobrenadante resultante foi transferido para microtubos contendo $600 \mu \mathrm{L}$ de isopropanol e os mesmos foram incubados por $3 \mathrm{~h} \mathrm{a}-20^{\circ} \mathrm{C}$. Posteriormente, os microtubos foram centrifugados a $12000 \mathrm{~g}$ por $20 \mathrm{~min}$, o sobrenadante foi descartado, e o pellet resultante foi lavado por duas vezes em etanol a 70\%. O pellet foi ressuspendido em $30 \mu \mathrm{L}$ de água ultrapura livre de DNAses e RNAses (Invitrogen). As amostras de DNA extraídas foram quantificadas em espectrofotômetro NanoDrop ${ }^{\circledR} 2000$ (Thermo Fisher Scientific, Inc.), e posteriormente armazenadas em microtubos 
de polipropileno de $1,5 \mathrm{~mL}$ em freezer a $-80^{\circ} \mathrm{C}$ até a análise de qPCR conforme descrito no item 3.2.7.

\subsection{RESULTADOS}

\subsubsection{Resultado da infecção - sinais clínicos}

Os camundongos infectados pelo BoHV-5 por via intracraniana, bem como os animais do grupo controle não apresentaram sinais neurológicos evidentes e os mesmos sobreviveram até o $15 \mathrm{DPI}$.

\subsubsection{Análise histológica e imuno-histoquímica (IHQ)}

Em todos os camundongos inoculados com o BoHV-5, foi possível visualizar a área de inoculação, a qual geralmente estava presente no diencéfalo caudal, área próxima ao hipocampo. Por vezes, foi observada a área de inoculação em mesencéfalo rostral. Nos camundongos inoculados com BoHV-5, lesões histológicas foram visualizadas até o $10 \mathrm{DPI}$. As lesões se localizavam principalmente no diencéfalo caudal e eram caracterizadas por espongiose focalmente extensa com áreas de liquefeitas (necrose de liquefação) do neurópilo, associada a grande quantidade de células da glia (gliose) e a uma menor quantidade de linfócitos, macrófagos e raros neutrófilos (Figura 1). Havia também macrófagos contendo pigmento intracitoplasmático levemente amarronzado (hemossiderina). No 4 e $5 \mathrm{DPI}$, na periferia e associado à área de inoculação, visualizaram-se manguitos perivasculares, principalmente compostos por uma a três fileiras de linfócitos, macrófagos e plasmócitos (Figura 2). Principalmente no diencéfalo caudal dos camundongos inoculados com BoHV-5 do 5 DPI foi visualizada periventriculite e meningite, composta principalmente por macrófagos, linfócitos, plasmócitos e raros neutrófilos, localmente extensa de variados graus de intensidade (Figura 3), que variava de leve a acentuada. Também foi observada meningite, composta por 
macrófagos, linfócitos, plasmócitos e raros neutrófilos, que se localizava principalmente em diencéfalo rostral, diencéfalo caudal, mesencéfalo rostral e cerebelo e variava de leve a moderada (Figuras 4 e 5). No grupo controle, somente em um animal foi possível localizar a área de inoculação, na qual foi possível observar espongiose e gliose focais e leves. Nestes animais do grupo controle, nos dias analisados, não havia inflamação significativa no SNC

Figura 1 - SNC, diencéfalo rostral, de camundongo BALB/c inoculado com BoHV-5, 5 DPI

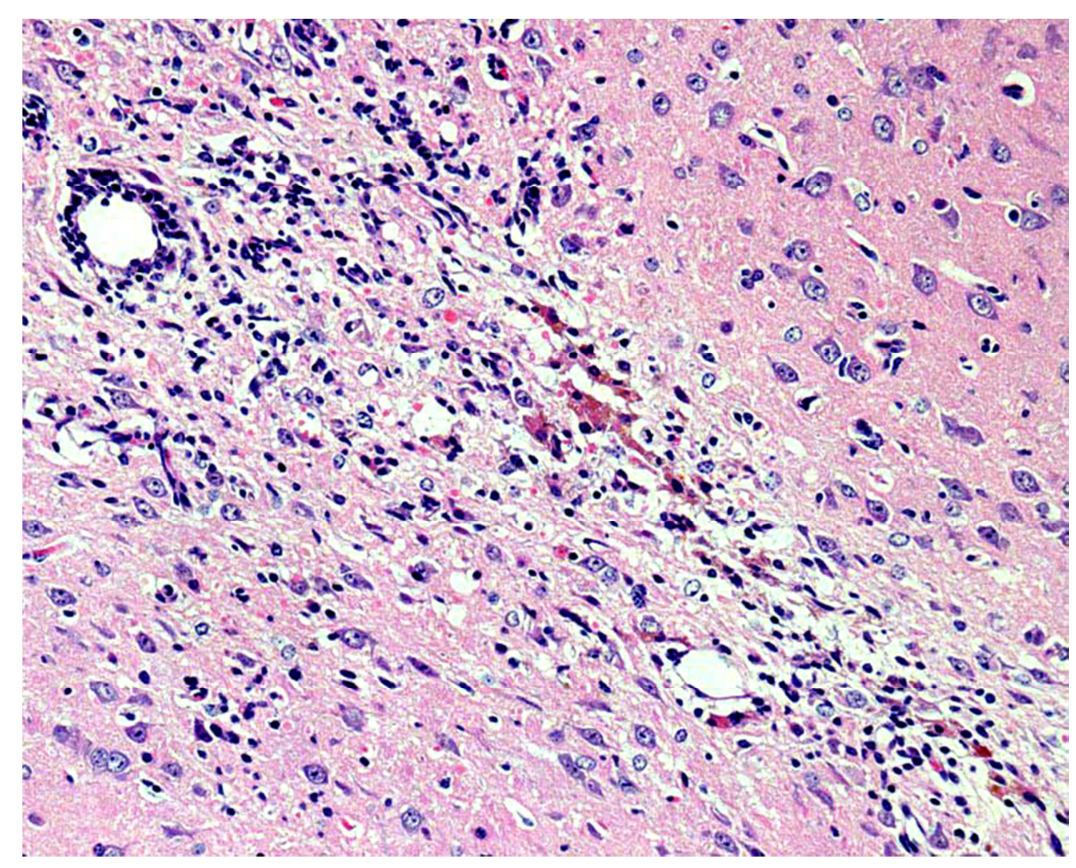

Fonte: (MESQUITA, L. P., 2016)

Legenda: Espongiose focalmente extensa com áreas de liquefeitas (necrose de liquefação) do neurópilo, associada a grande quantidade de células da glia (gliose) e a uma menor quantidade de linfócitos, macrófagos e raros neutrófilos, e manguito perivascular (canto superior esquerdo). HE, obj. 20x. 
Figura 2 - SNC, diencéfalo rostral, de camundongo BALB/c inoculado com o BoHV-5, 5 DPI

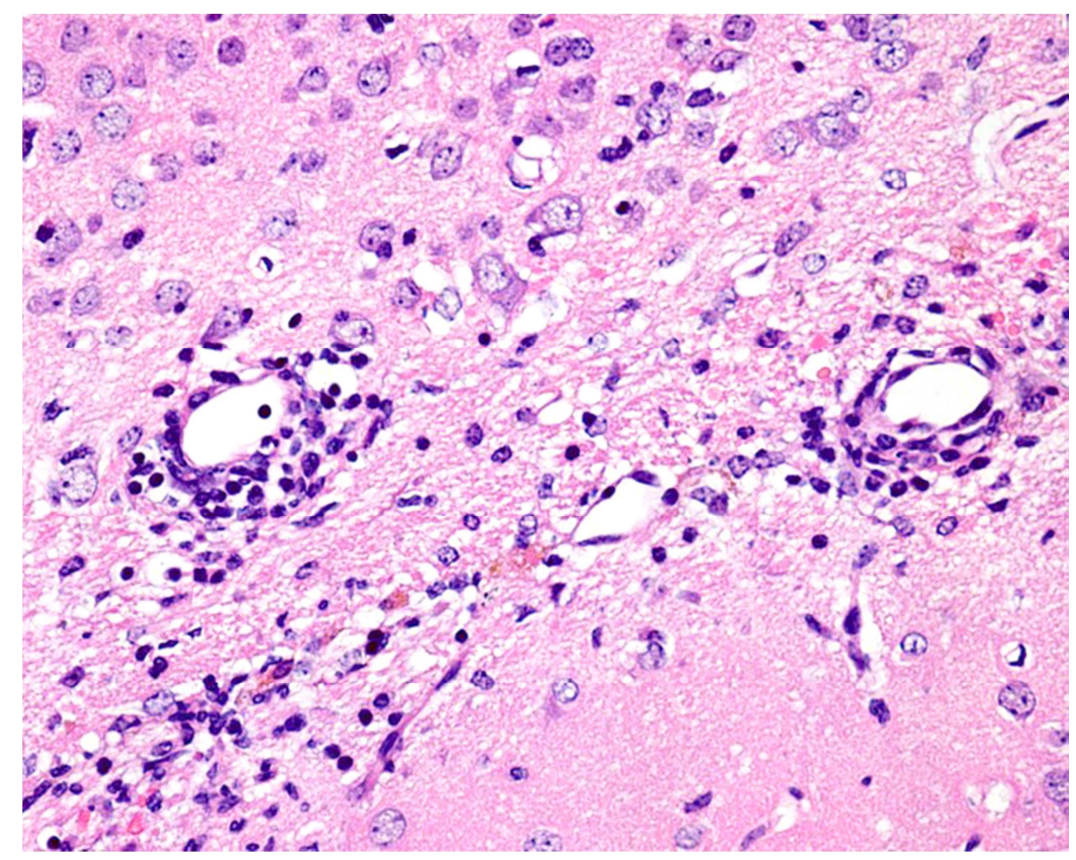

Fonte: (MESQUITA, L. P., 2016)

Legenda: Manguitos perivasculares compostos por uma a três fileiras de linfócitos, macrófagos e plasmócitos. HE, obj. 40x.

Figura 3 - SNC, diencéfalo rostral, de camundongo BALB/c inoculado com o BoHV-5, 5 DPI

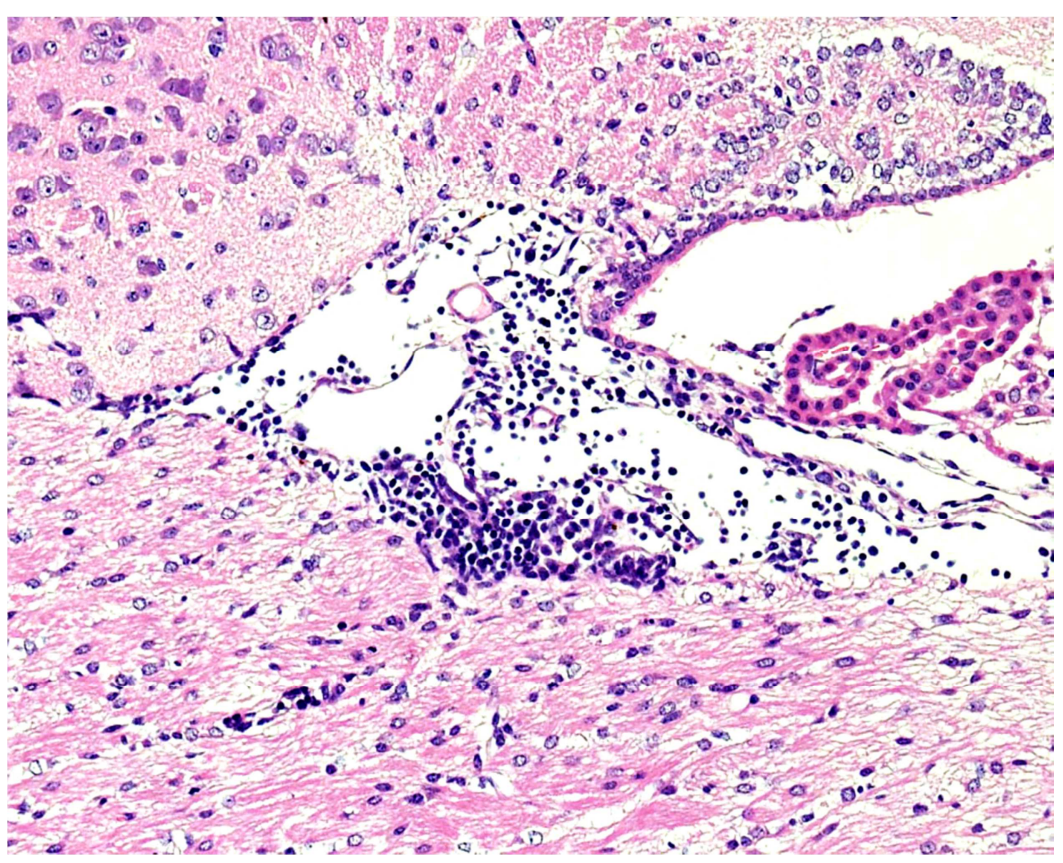

Fonte: (MESQUITA, L. P., 2016)

Legenda: Periventriculite acentuada, focalmente extensa, composta principalmente por macrófagos, linfócitos, plasmócitos e raros neutrófilos. HE, obj. 20x. 
Figura 4 - SNC, diencéfalo rostral, de camundongo BALB/c inoculado com o BoHV-5, 5 DPI

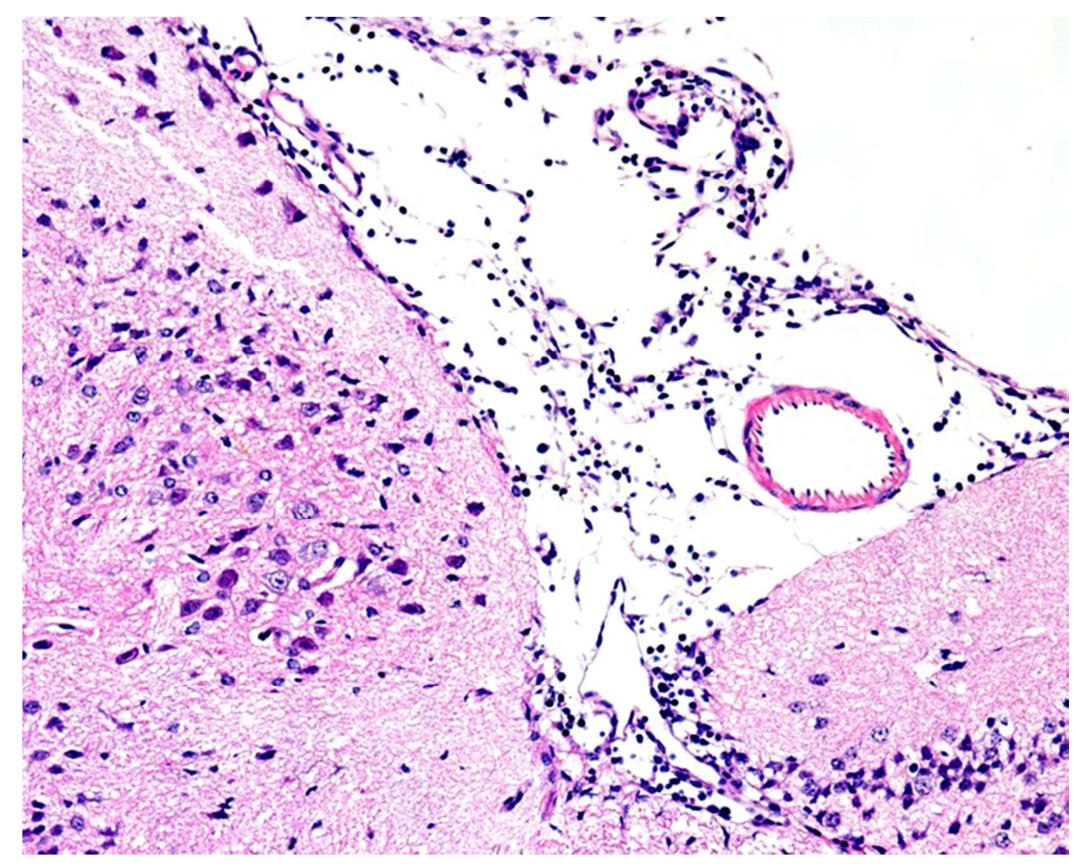

Fonte: (MESQUITA, L. P., 2016)

Legenda: Meningite focalmente extensa moderada, composta principalmente por macrófagos, linfócitos, plasmócitos e raros neutrófilos. HE, obj. 20x.

Figura 5 - SNC, diencéfalo rostral, de camundongo BALB/c inoculado com o BoHV-5, 5 DPI

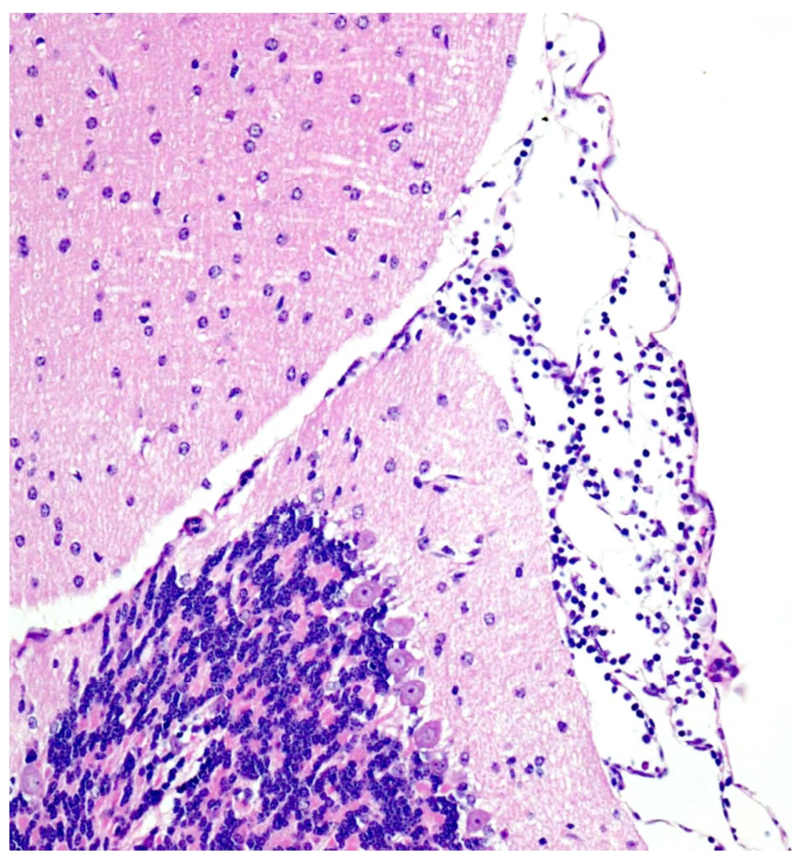

Fonte: (MESQUITA, L. P., 2016)

Legenda: Meningite focalmente extensa moderada, composta principalmente por macrófagos, linfócitos, plasmócitos e raros neutrófilos. HE, obj. 20x. 
$\mathrm{Na}$ análise IHQ, no SNC de bovino infectado pelo BoHV-5 utilizado como controle positivo para a reação de $\mathrm{IHQ}$, os antígenos virais foram detectados em células inflamatórias, principalmente naquelas presentes nos manguitos perivasculares (Figura 6), citoplasma e núcleos de neurônios, por vezes estes estavam degenerados e necróticos (Figura 7), e neurópilo. Em todos os camundongos inoculados com BoHV-5 foram visualizadas marcações para os antígenos de BoHV-5 nos cortes de SNC. A marcação foi mais intensa no 3, 4, 5, 6 e $7 \mathrm{DPI}$. Os antígenos de BoHV-5 estavam presentes principalmente nas áreas de inoculação. Nestas áreas, os antígenos foram visualizados no neurópilo, em citoplasma de células inflamatórias, células da glia e endotélio vascular (Figura 8). As marcações para BoHV-5 também estavam presentes no citoplasma de células inflamatórias, principalmente macrófagos, nas áreas de periventriculite e meningite (Figuras 9 e 10). Não foram visualizadas marcações no SNC dos camundongos do grupo controle.

Análises do gânglio trigeminal revelaram que no 6 DPI, grande quantidade de antígenos virais foram visualizados no citoplasma de neurônios (Figura 11). Neste gânglio trigeminal lesões histológicas não foram detectadas.

Figura 6 - SNC de bovino naturalmente infectado pelo BoHV-5, controle positivo

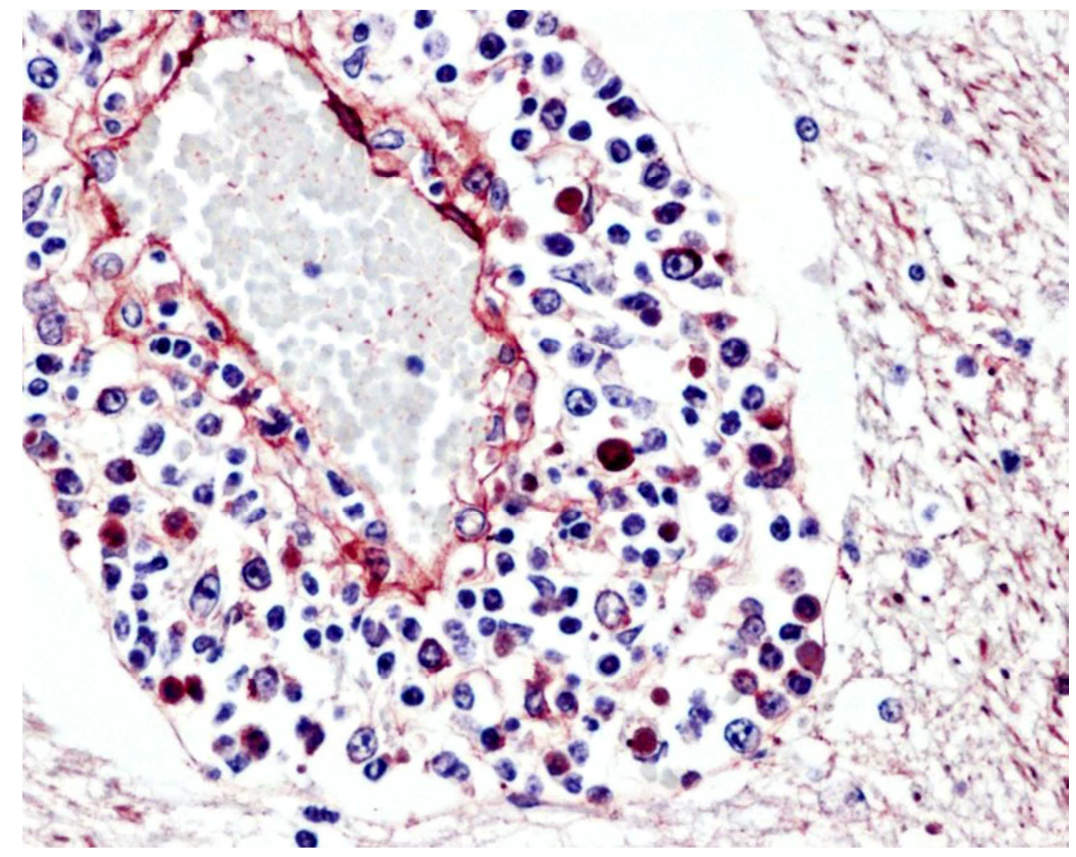

Fonte: (MESQUITA, L. P., 2016)

Legenda: Córtex cerebral, manguito perivascular. Visualizam-se marcações (em vermelho-tijolo) no citoplasma, principalmente de macrófagos, bem como no neurópilo adjacente. Método biotina-estreptavidina-peroxidase. Vector NovaRed ${ }^{\circledR}$, obj. 60x. 
Figura 7 - SNC de bovino naturalmente infectado pelo BoHV-5, controle positivo

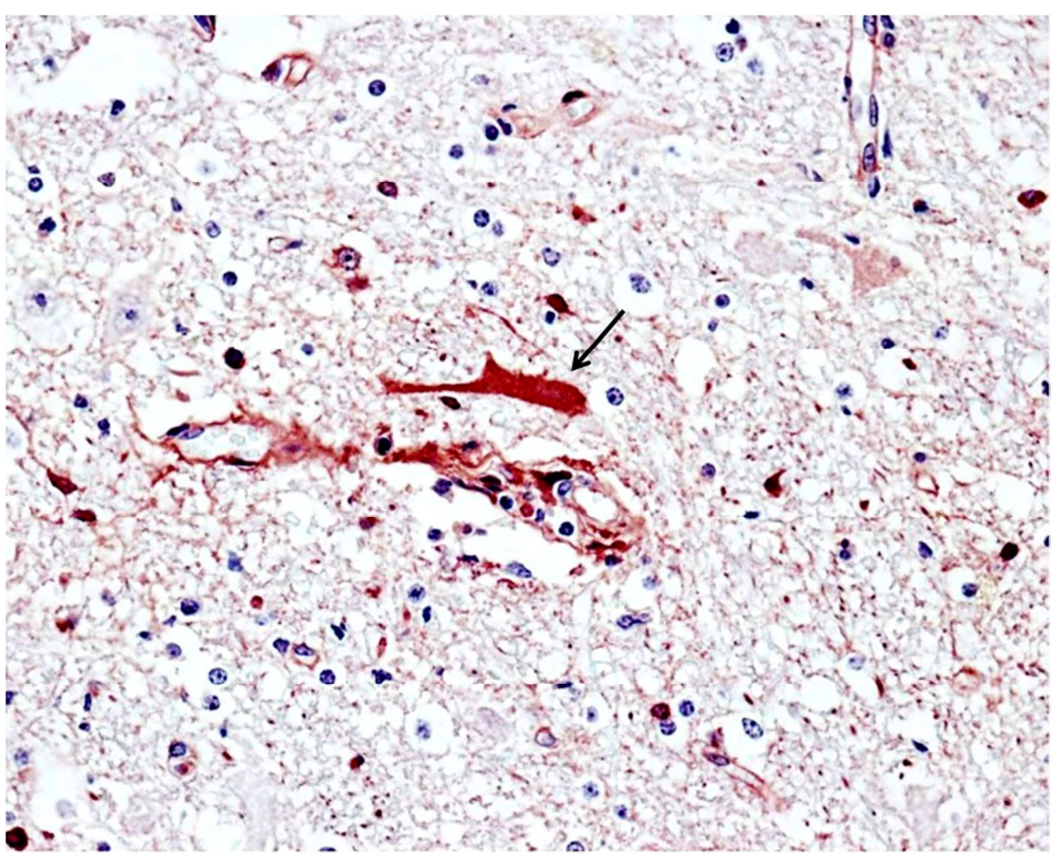

Fonte: (MESQUITA, L. P., 2016)

Legenda: Córtex cerebral. Nota-se marcação para antígeno de BoHV-5 em citoplasma de neurônio necrótico (seta). Método biotina-estreptavidina-peroxidase. Vector NovaRed ${ }^{\circledR}$, obj. 60x.

Figura 8 - SNC, diencéfalo caudal, de camundongo BALB/c inoculado com o BoHV-5, 5 DPI

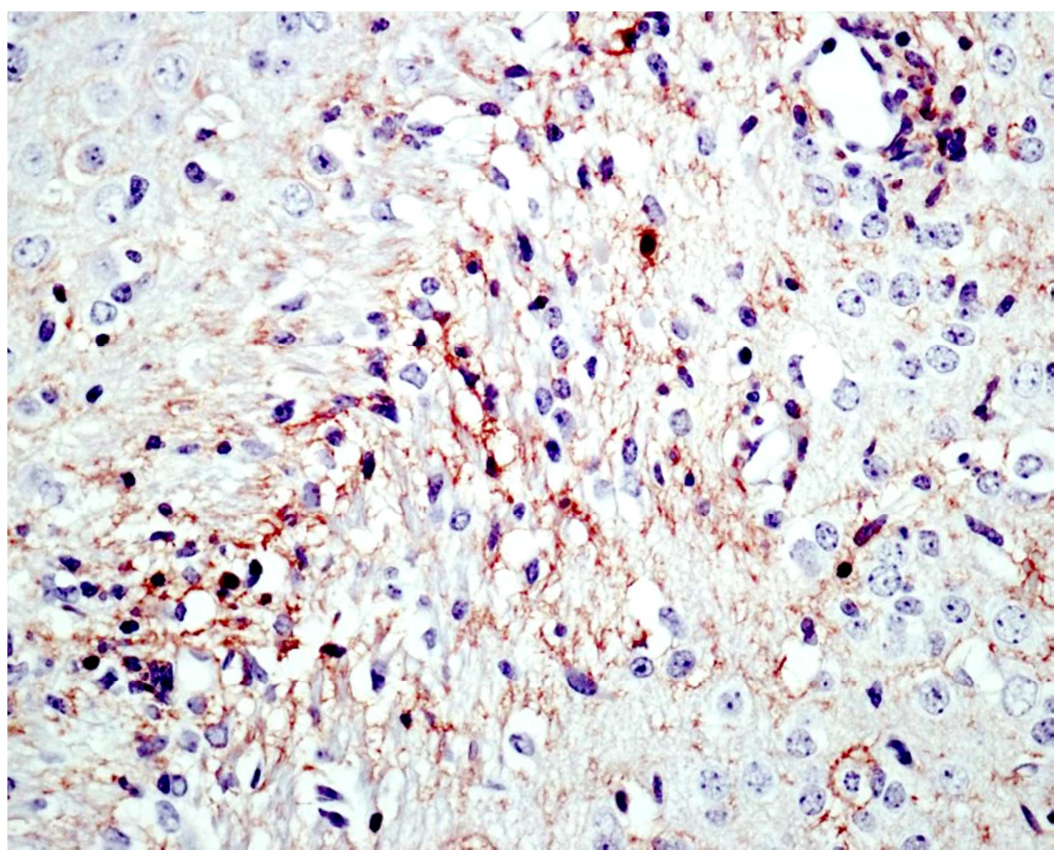

Fonte: (MESQUITA, L. P., 2016)

Legenda: Visualizam-se marcações para o BoHV-5 no neurópilo e citoplasma de células da glia. Método biotina-estreptavidina-peroxidase. Vector NovaRed ${ }^{\circledR}$, obj. 40x 
Figura 9 - SNC, diencéfalo caudal, de camundongo BALB/c inoculado com o BoHV-5, 5 DPI

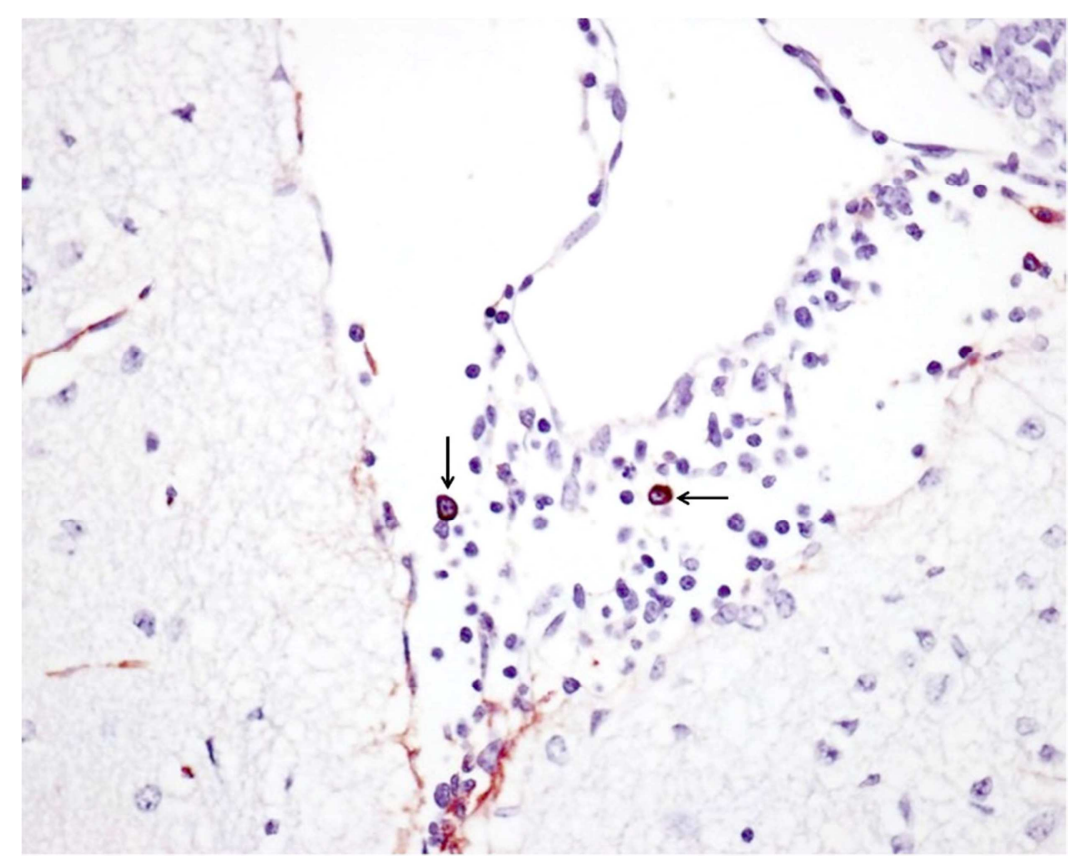

Fonte: (MESQUITA, L. P., 2016)

Legenda: Área de periventriculite. Notam-se marcações intracitoplasmáticas em macrófagos (setas). Método biotina-estreptavidina-peroxidase. Vector NovaRed ${ }^{\circledR}$, obj. 40x.

Figura 10 - SNC, diencéfalo caudal, de camundongo BALB/c inoculado com o BoHV-5, 5 DPI

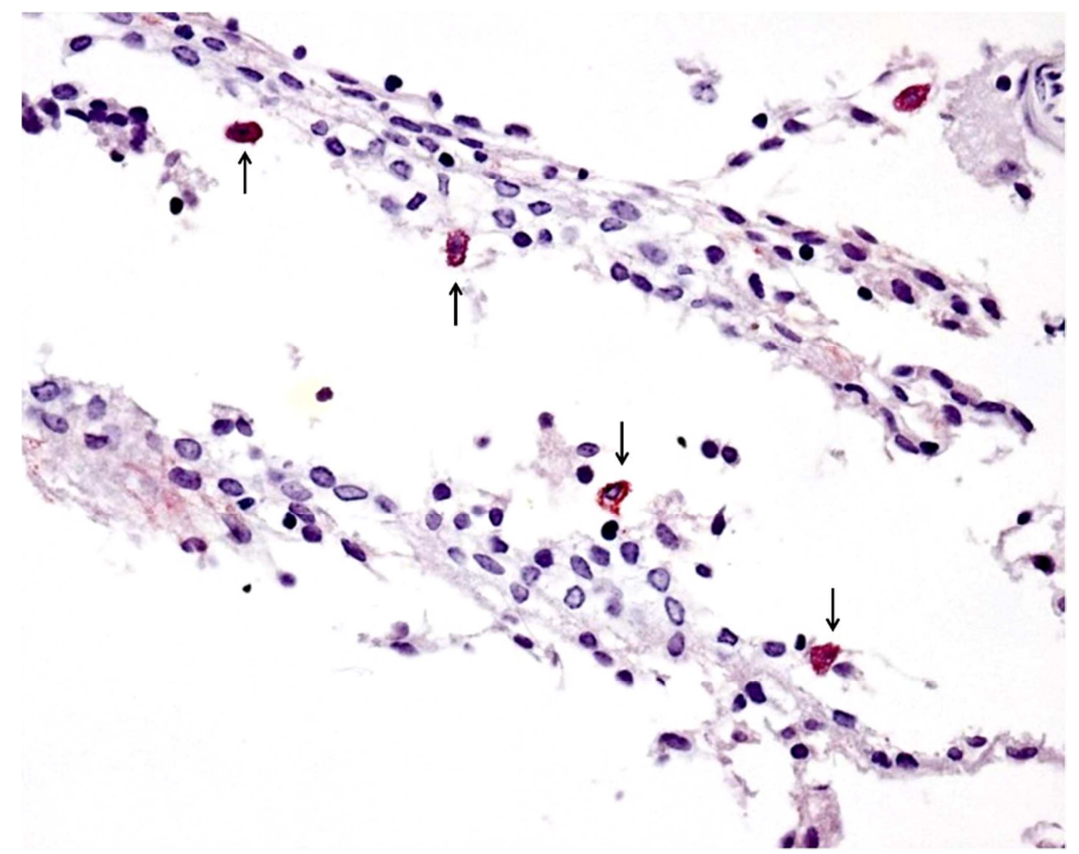

Fonte: (MESQUITA, L. P., 2016)

Legenda: Área de meningite. Notam-se marcações intracitoplasmáticas em macrófagos (setas). Método biotina-estreptavidina-peroxidase. Vector NovaRed ${ }^{\circledR}$, obj. 40x. 
Figura 11 - Gânglio trigeminal de camundongo BALB/c inoculado com o BoHV-5, 6 DPI

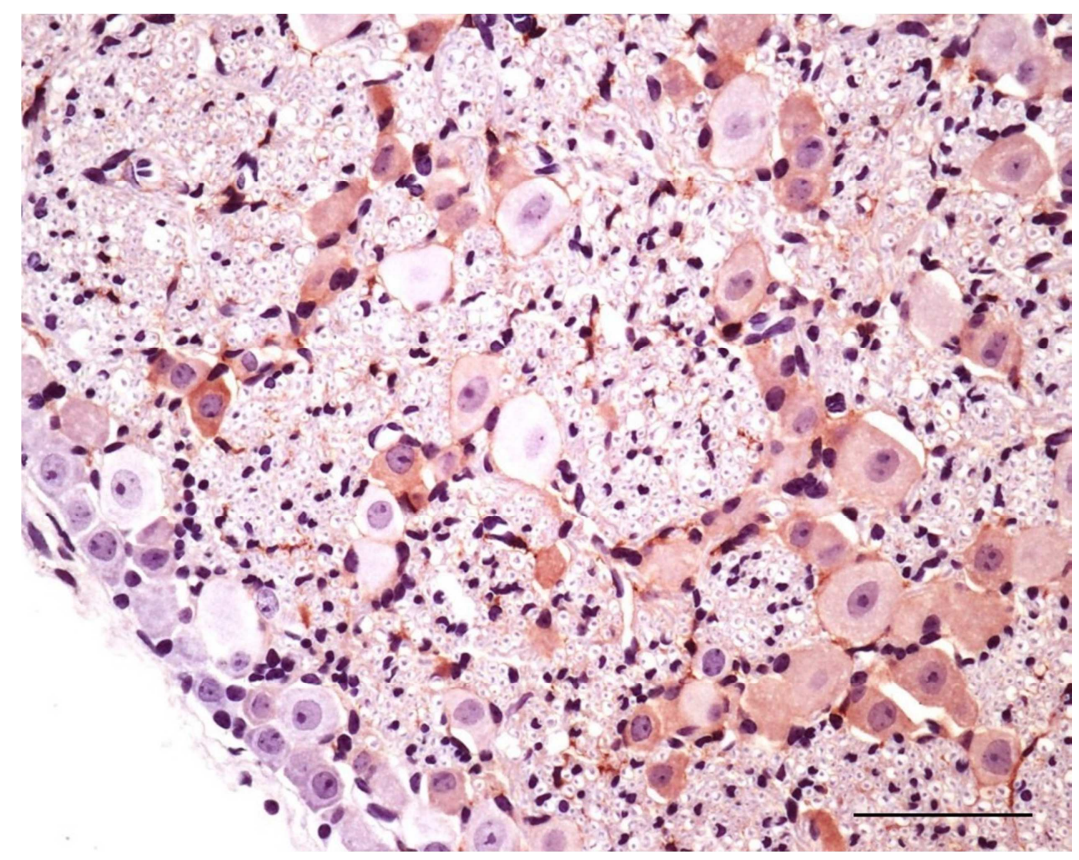

Fonte: (MESQUITA, L. P., 2016)

Legenda: Visualizam-se marcações para o BoHV- 5 no citoplasma e neurônios. Método biotinaestreptavidina-peroxidase. VectorNovaRed ${ }^{\circledR}$, obj. 40x

\subsubsection{Expressão gênica de citocinas e quimiocina pró-inflamatórias}

O nível de mRNA para as citocinas IFN- $y$, TNF- $\alpha$, IL-6 e quimiocina CCL-2 (MCP-1) no SNC de camundongos BALB/c inoculados com o BohV-5 foi realizado por meio de qPCR em tempo real de quantificação relativa em comparação ao grupo controle, o qual foi inoculado com EMEM extraído de células MDBK. A mensuração dos níveis de mRNA para estas citocinas e quimiocina próinflamatórias foi realizada em diferentes $\operatorname{DPI}(3,4,5,6,7,8,10$, e 15) com quatro animais em cada grupo.

No SNC dos camundongos infectados pelo BoHV-5 houve aumento significativo na expressão gênica das citocinas IFN-y $(p<0,0001)$, TNF- $\alpha$ ( $p<$ $0,0001$ ) e quimiocina CCL-2 ( $<<0,0001)$, em relação ao grupo controle. Ao passo que não houve diferença estatística entre os camundongos inoculados com BoHV-5 e o grupo controle em relação a expressão de IL-6 ( $p$ > 0.05) ao longo do tempo.

Os níveis de mRNA que codificam IFN-y estavam significativamente aumentados no grupo infectado pelo BoHV-5 em todos dias analisados, exceto no 
10 DPI (Gráfico 1). O aumento da expressão de IFN-y em relação ao grupo controle foi detectada principalmente nos dias iniciais da infecção (3 e 4 DPI), assim como no 15 DPI. A expressão gênica da quimiocina CCL-2 (MCP-1) estava significativamente aumentada em relação ao grupo controle nos SNC dos camundongos infectados pelo BoHV-5 no 3, 4, 6 e 15 DPI (Gráfico 2), sendo mais acentuados no início da infecção (3 e $4 \mathrm{DPI}$ ) e $15 \mathrm{DPI}$. Ao passo que os níveis de mRNA que codificam a citocina TNF-a, estavam principalmente aumentados no início da infecção (3 e 4 DPI), e no 15 DPI (Gráfico 3). No tocante a expressão de IL-6, não foram observadas diferenças entre os camundongos inoculados com BoHV-5 e o grupo controle em nenhum dos dias analisados (Gráfico 4).

Gráfico 1- Níveis do mRNA que codifica o IFN-y no SNC de camundongos BALB/c infectados com o BoHV-5 em diferentes dias pós-inoculação

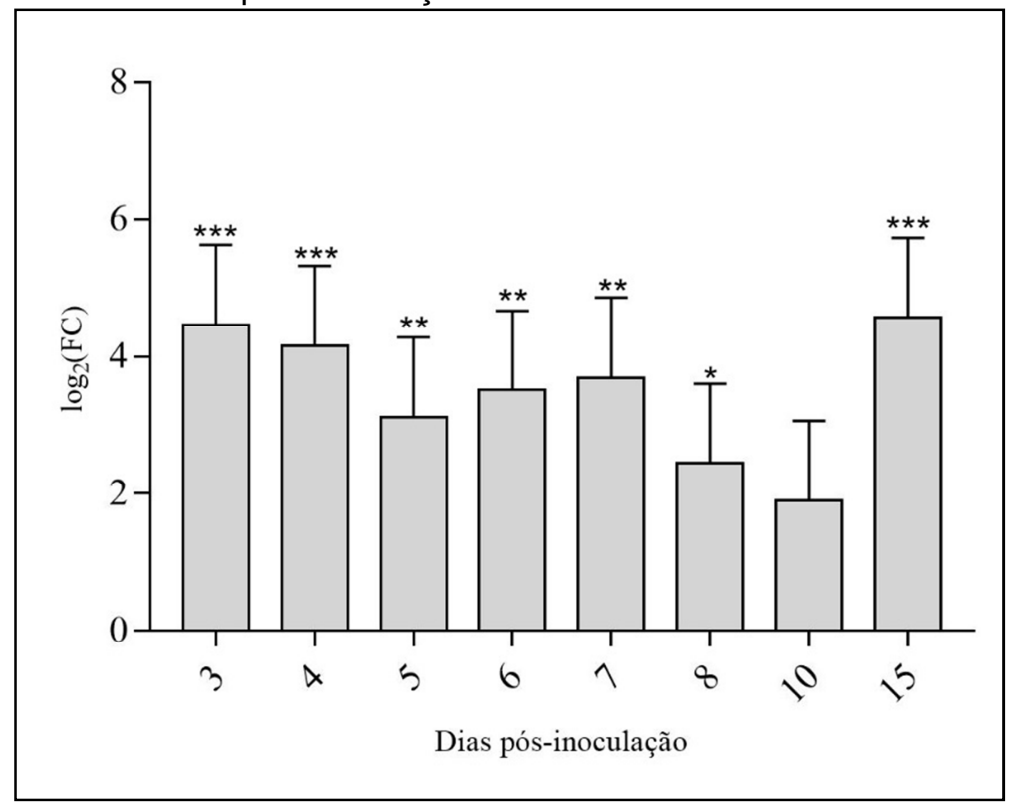

Fonte: (MESQUITA, L. P., 2016)

Legenda: Os valores relativos da expressão gênica estão apresentados como $\log _{2}(F C)$ no SNC de camundongos infectados com o BoHV-5 em relação ao controle negativo definido como 0 . As barras indicam um intervalo de confiança de $95 \%\left({ }^{*} p<0,05 ;{ }^{*} p<0,01 ;{ }^{*} p<0,001\right)$. 
Gráfico 2 - Níveis do mRNA que codifica o CCL-2 (MCP-1) no SNC de camundongos BALB/C infectados com o BoHV-5 em diferentes dias pós-inoculação

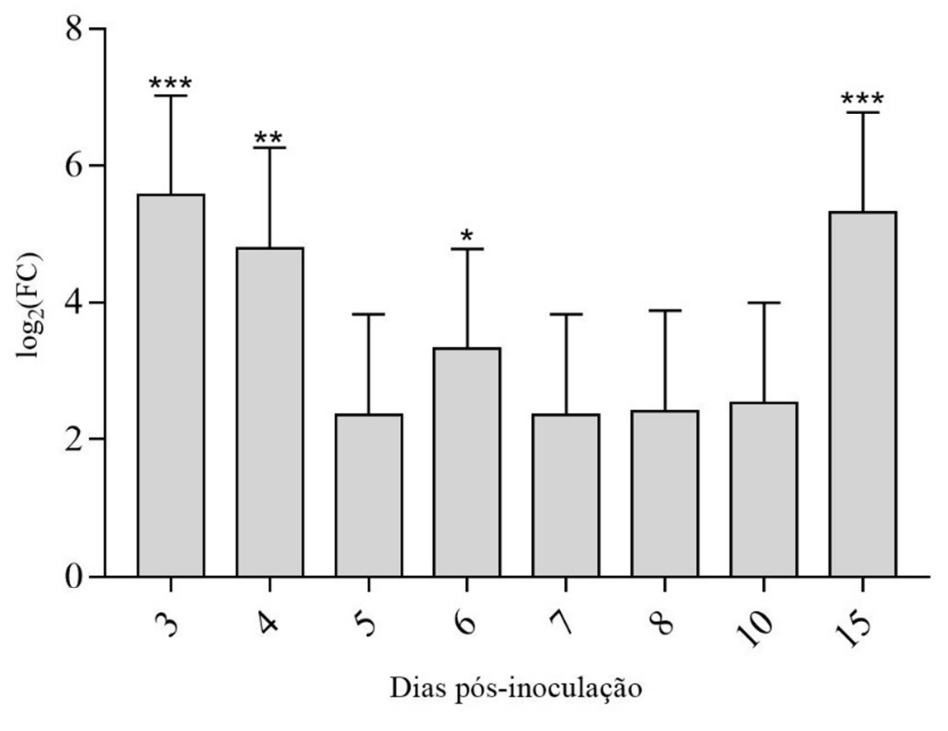

Fonte: (MESQUITA, L. P., 2016)

Legenda: Os valores relativos da expressão gênica estão apresentados como $\log _{2}(F C)$ no $S N C$ de camundongos infectados com o BoHV-5 em relação ao controle negativo definido como 0. As barras indicam um intervalo de confiança de $95 \%$ ( $\left.p<0,05 ;{ }^{*} p<0,01 ;{ }^{*} p<0,001\right)$.

Gráfico 3 - Níveis do mRNA que codifica o TNF-a no SNC de camundongos BALB/c infectados com o BoHV-5 em diferentes dias pós-inoculação

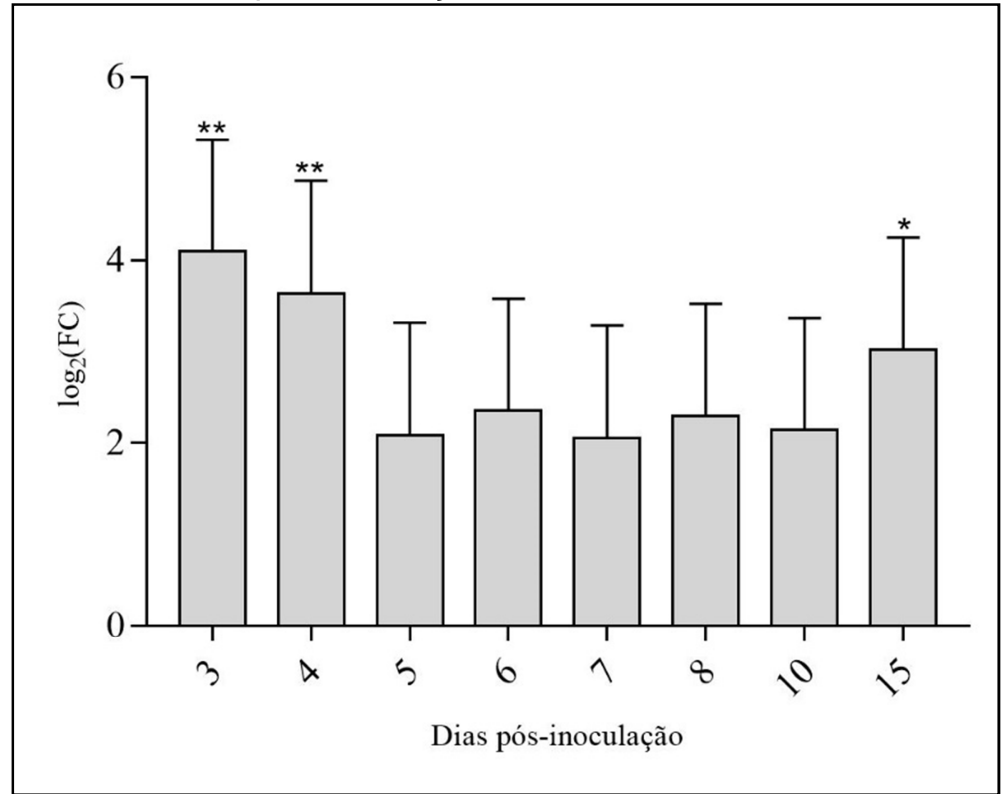

Fonte: (MESQUITA, L. P., 2016)

Legenda: Os valores relativos da expressão gênica estão apresentados como $\log _{2}(F C)$ no SNC de camundongos infectados com o BoHV-5 em relação ao controle negativo definido como 0. As barras indicam um intervalo de confiança de $95 \%$ ( $\left.p<0,05 ;{ }^{*} p<0,01 ;{ }^{*} p<0,001\right)$. 
Gráfico 4 - Níveis do mRNA que codifica o IL-6 no SNC de camundongos BALB/c infectados com o BoHV-5 em diferentes dias pós-inoculação

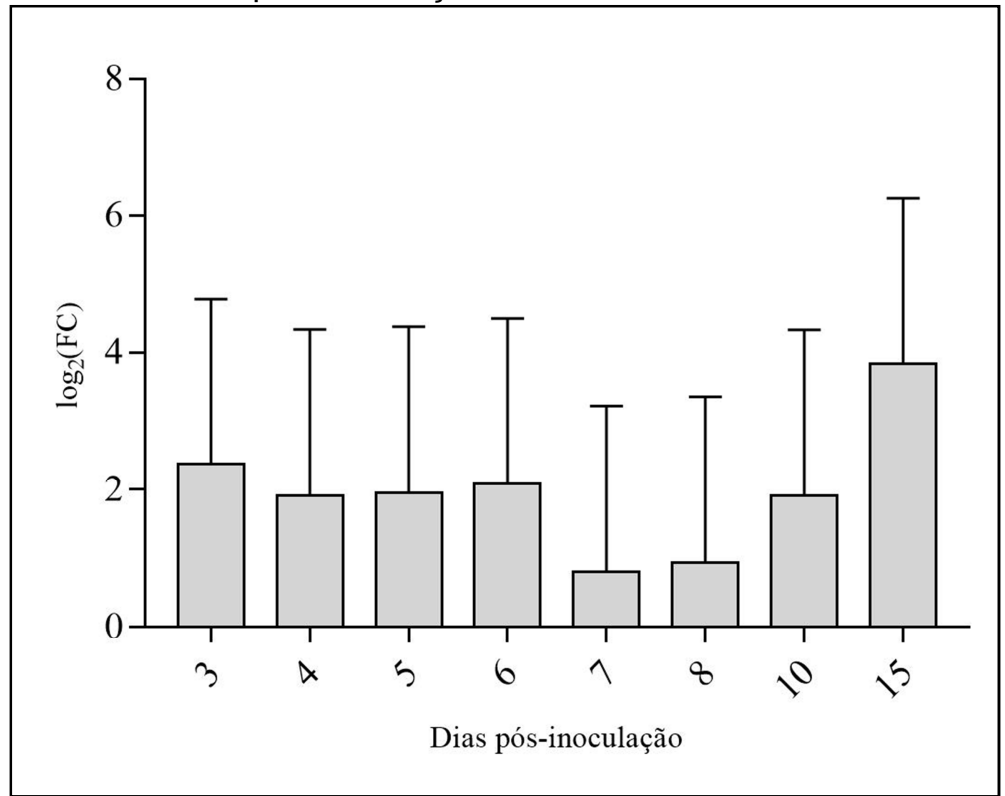

Fonte: (MESQUITA, L. P., 2016)

Legenda: Os valores relativos da expressão gênica estão apresentados como $\log _{2}(F C)$ no $S N C$ de camundongos infectados com o BoHV-5 em relação ao controle negativo definido como 0. As barras indicam um intervalo de confiança de $95 \%$ ( $\left.p<0,05 ;{ }^{*} p<0,01 ;{ }^{*} p<0,001\right)$.

\subsubsection{Isolamento viral}

No isolamento viral foi possível isolar o BoHV-5 do SNC dos camundongos inoculados com o vírus na primeira passagem em células MDBK nos dias 3, 4, 5 e 6 DPI (Figura 12), demonstrando, portanto, a existência de partículas virais viáveis no SNC destes camundongos até o $6 \mathrm{DPI}$. 
Figura 12 - Isolamento viral em células MDBK, SNC de camundongo BALB/c inoculado com o BoHV-5, 6 DPI

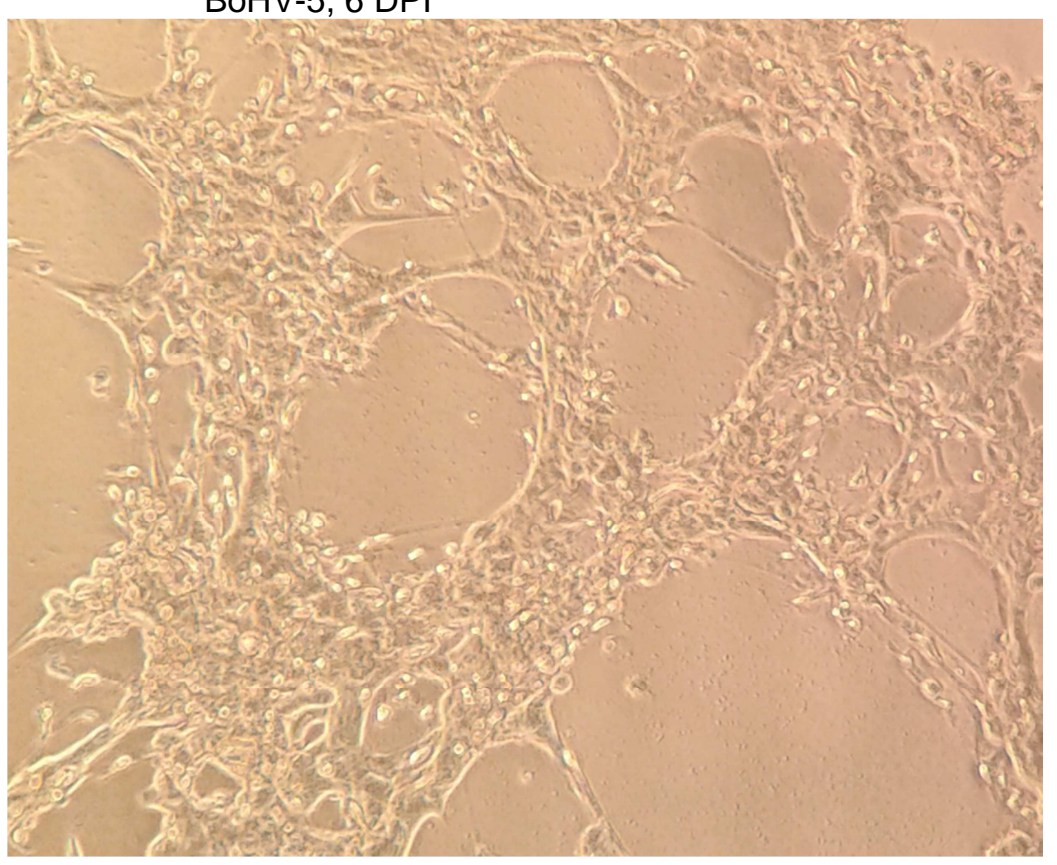

Fonte: (MESQUITA, L. P., 2016)

Legenda: Nestas células MDBK inoculadas com SNC de camundongo infectado pelo BoHV-5, observa-se o efeito citopático do vírus caracterizado por um aumento da refração e desprendimento de células, obj. 10x.

\subsubsection{Quantificação absoluta de BoHV-5 por qPCR em tempo real}

A qPCR absoluta em tempo real para detecção e quantificação de um fragmento do gene UL30 amplificou um fragmento de $160 \mathrm{pb}$, o que foi confirmado por PCR convencional do plasmídeo inserido por meio de clonagem em células $E$ coli TOP10 (Figura 13). Por meio desta qPCR foi possível detectar e quantificar partículas virais de 1 até $10^{8}$ cópias do plasmídeo, sendo que cada cópia do plasmídeo equivale a uma partícula viral. A curva da APCR, com seis pontos ou diluições $\left(10^{7}, 10^{6}, 10^{5}, 10^{4}, 10^{3}\right.$ e $\left.10^{2}\right)$ (Figura 14), apresentou uma eficiência de $103,278 \%$, com um slope de $-3,246$ e $\mathrm{R}^{2}=0,997$ (Figura 15). 
Figura 13 - Fragmento amplificado de $160 \mathrm{pb}$ a partir de plasmídeo contendo fragmento do gene UL30 de BoHV-5 clonado em células E. coli TOP10

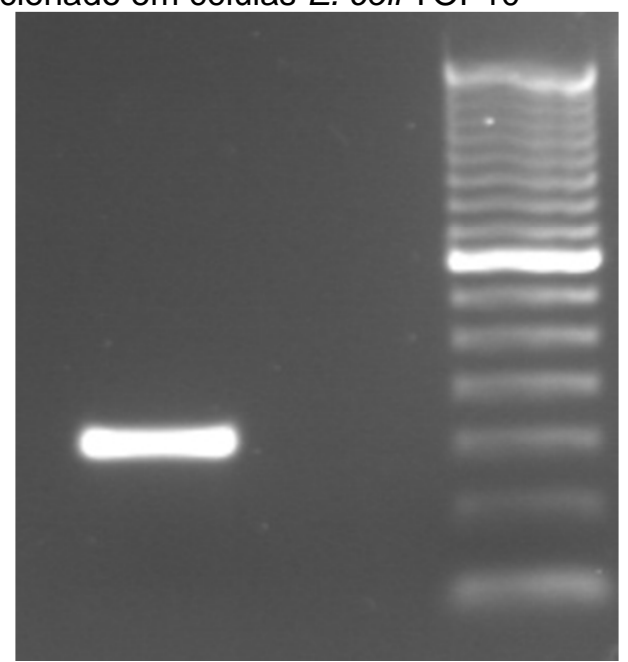

Fonte: (MESQUITA, L. P., 2016)

Legenda: Eletroforese em gel de agarose 1,5\%. Ladder (à direita): 50 pb.

Figura 14 - Curva padrão da QPCR absoluta em tempo real para detecção e quantificação do BoHV-5

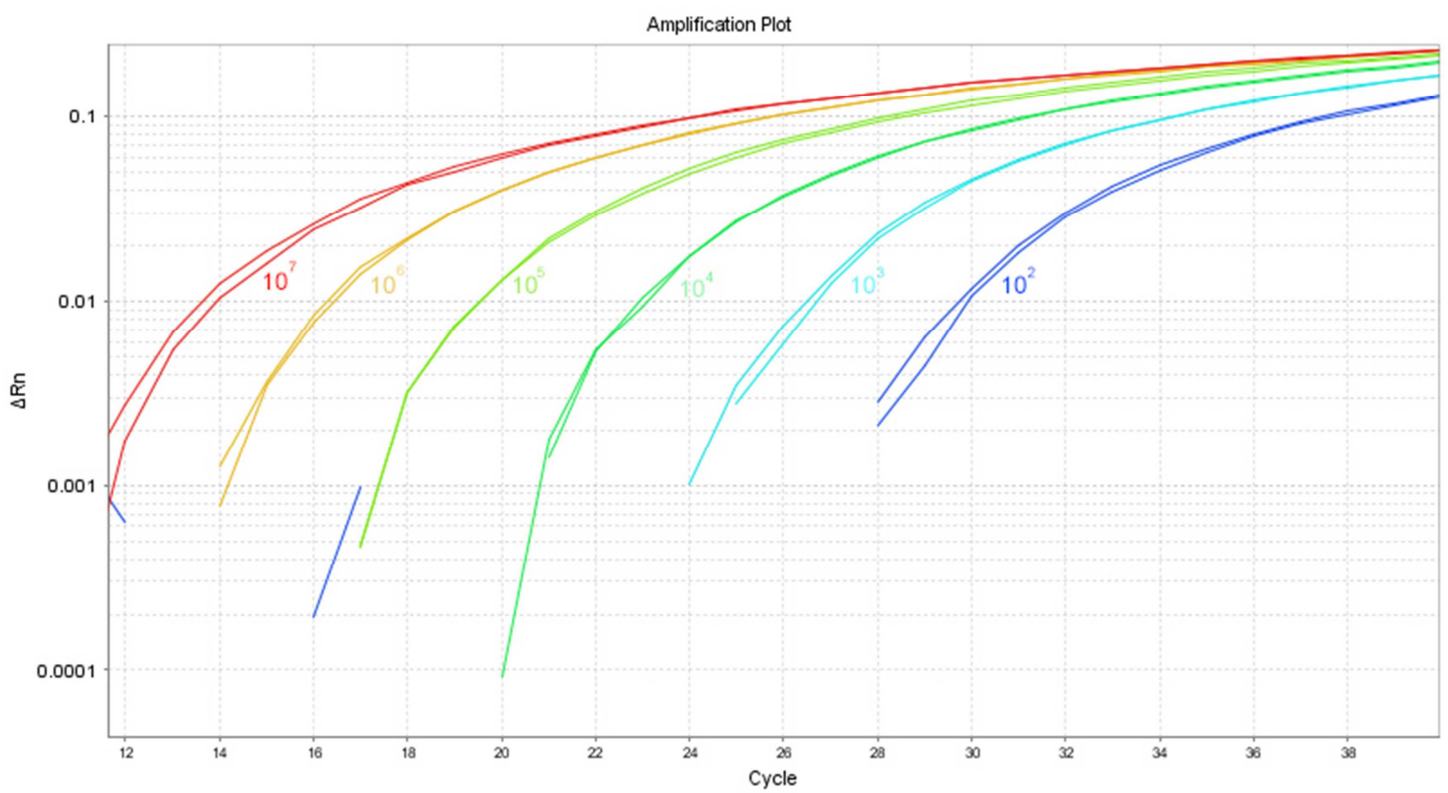

Fonte: (MESQUITA, L. P., 2016)

Legenda: Nesta curva para quantificação de BoHV-5 é possível observar os diferentes números de cópias do DNA viral $\left(10^{7}, 10^{6}, 10^{5}, 10^{4}, 10^{3}\right.$ e $\left.10^{2}\right)$. 
Figura 15 - Curva padrão da qPCR absoluta em tempo real para detecção e quantificação do BoHV-5

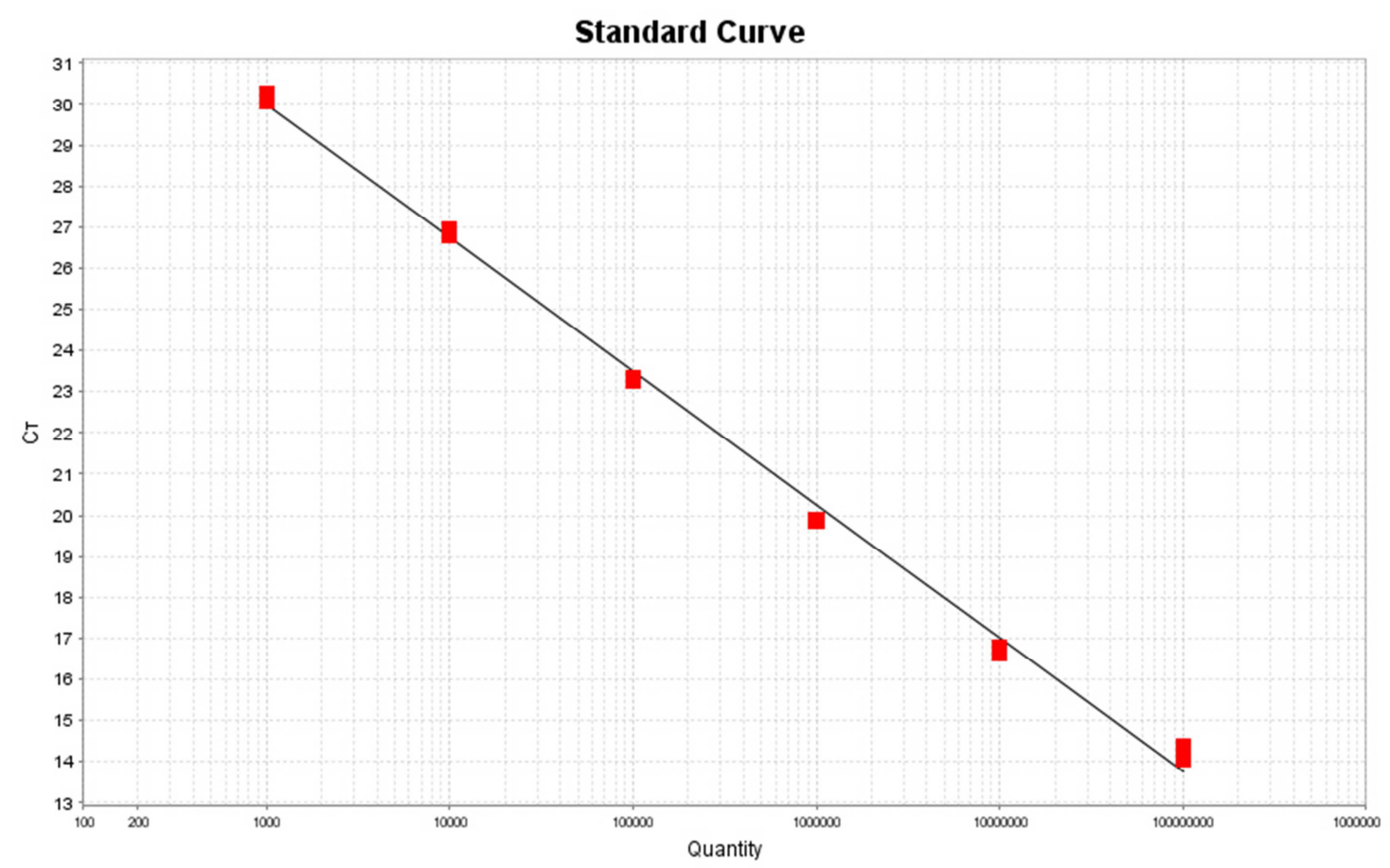

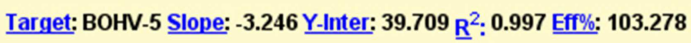

Fonte: (MESQUITA, L. P., 2016)

Legenda: A curva para quantificação de BoHV-5 apresentou eficiência de 103,278\%, com um slope de $-3,246$ e $R^{2}=0,997$.

A quantificação do número de cópias de BoHV-5 foi realizada em quatro animais de cada DPI (1, 2 e 3$)$. Os resultados desta quantificação estão apresentados no Gráfico 5. Houve um aumento no número de partículas virais do 1 DPI (média de 6.034 partículas) para o 2 DPI (média de 16.561 partículas) e $3 \mathrm{DPI}$ (média de 19.823 partículas). No SNC dos animais controle não foram detectadas cópias do DNA de BoHV-5.

Nas amostras de gânglio trigeminal foram detectadas um número significativo de cópias de BoHV-5 no 3 DPI, com uma média de 6077,6 partículas de BoHV-5. No gânglio trigeminal dos animais controle não foram detectadas partículas virais de BoHV-5. 
Gráfico 5 - Quantificação de BoHV-5 em amostras do SNC de camundongos infectados pelo BoHV-5

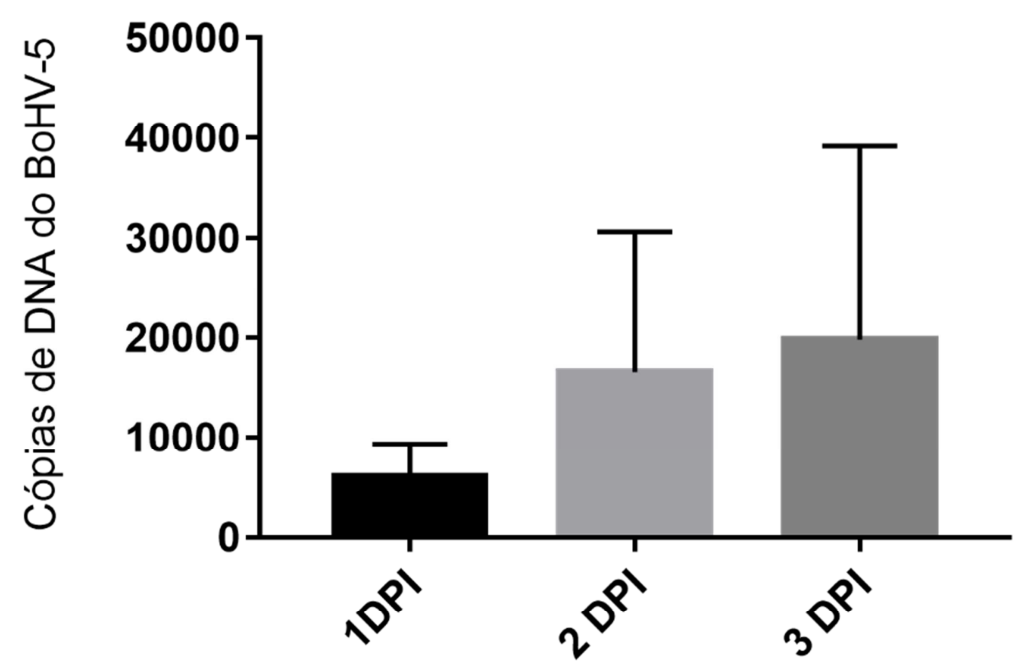

Dia pós-inoculação

Fonte: (MESQUITA, L. P., 2016)

Legenda: O gráfico representa a média de cada grupo. As barras de erro representam o desvio padrão.

\subsection{DISCUSSÃO}

O presente estudo teve como objetivo avaliar a cinética de replicação, bem como a resposta imune no SNC de camundongos BALB/C inoculados pela via intracraniana com o BoHV-5. Os achados dos experimentos aqui descritos sugerem fortemente que o BoHV-5 foi capaz de infectar e replicar no encéfalo de camundongos BALB/c, gerando uma resposta imune importante no SNC. Embora a via intracraniana não seja fiel à infecção no hospedeiro natural, a mesma foi escolhida no presente estudo para verificar se os camundongos BALB/c são permissíveis e susceptíveis à infecção pelo BoHV-5, uma vez que resultados preliminares obtidos em nosso laboratório e outros escassos dados de literatura (SILVA et al., 1999; BELTRÃO et al., 2000; ABRIL et al., 2004), demonstraram que camundongos wild-type não são susceptíveis à infecção do SNC por outras vias (intranasal e intraperitoneal). 
Os resultados de expressão gênica de citocinas e quimiocina próinflamatórias demonstraram uma resposta imunológica importante no SNC com aumento significativo de IFN- $\gamma$, CCL-2 e TNF- $\alpha$ no SNC de camundongos infectados com o BoHV-5 em diferentes dias pós-inoculação quando comparados ao grupo controle. Apesar de estar aumentada em todos os dias, exceto no $10 \mathrm{DPI}$, a expressão de IFN-y em relação ao grupo controle foi detectada principalmente nos dias iniciais da infecção (3 e 4 DPI), assim como no 15 DPI. Semelhantemente, os níveis de mRNA que codificam a quimiocina CCL-2 (MCP-1) estavam aumentados em diferentes dias pós-inoculação, sendo mais acentuados no início da infecção (3 e $4 \mathrm{DPI}$ ) e $15 \mathrm{DPI}$. Ao passo que os níveis de mRNA que codificam a citocina TNF- $\alpha$, estavam aumentados somente no início da infecção (3 e $4 \mathrm{DPI}$ ), e no $15 \mathrm{DPI}$. Diferentemente, não foram observadas diferenças na expressão gênica de IL-6 entre os camundongos inoculados com BoHV-5 e o grupo controle em nenhum dos dias analisados. Notavelmente, pode-se afirmar que os resultados aqui apresentados revelaram um padrão na expressão de determinadas citocinas e quimiocina próinflamatórias, principalmente de IFN- $\gamma$, CCL-2 e TNF- $\alpha$, no qual há aumento nos níveis de mRNA que codificam essas proteínas nos dias iniciais de infecção (3 e 4 DPI) seguida por um outro aumento significativo no $15 \mathrm{DPI}$. Em camundongos wildtype infectados pela via intraperitoneal foi demonstrado que há produção de anticorpos, mesmo que pequena, principalmente de IgG2, indicando uma resposta do tipo Th1 (ABRIL et al., 2004). Semelhantemente, no presente estudo, o padrão de citocinas expressos, incluindo IFN- $y$, indicam um tipo de resposta Th1. Entretanto, ainda são escassos os estudos sobre a resposta imunológica na infecção pelo BoHV-5. Em camundongos transgênicos com deficiência na produção de linfócitos $B$ e T (deleção em ambas as cópias do gene RAG-2) e deficiência nos sistemas IFN $\alpha / \beta$ morreram em decorrência da infecção, porém os mesmos não desenvolveram quaisquer alterações inflamatórias no encéfalo (ABRIL et al., 2004). Semelhantemente ao presente estudo, em camundongos infectados pelo herpes simplex vírus tipo 1 (HSV-1) observou-se um aumento na expressão gênica de IFN-Y e TNF- $\alpha$ no gânglio trigeminal tanto na infecção aguda como na infecção latente (CANTIN et al., 1995). TNF- $\alpha$, assim como outras citocinas tais como IL-6, no SNC são comumente produzidas por células inflamatórias e células residentes tais como astrócitos e micróglia em infecções virais no SNC tais como aquelas causadas pelo vírus da encefalomielite murina no SNC (LIBBEY et al., 2011). 
As citocinas e quimiocinas expressas no SNC dos camundongos BALB/C inoculados com o BoHV-5 muito provavelmente contribuíram para 0 desenvolvimento da meningo-encefalite observada nos animais do presente estudo. A expressão mais significativa de IFN- $\mathrm{\gamma}$, CCL-2 e TNF- $\alpha$ nos 3 e 4 DPI, antecedeu o influxo de células inflamatórias para 0 SNC, as quais foram observadas principalmente no 4 e $5 \mathrm{DPI}$. A meningo-encefalite nos animais inoculados com 0 BoHV-5 era caracterizada principalmente por espongiose focalmente extensa com áreas liquefeitas (necrose de liquefação) do neurópilo, associada a grande quantidade de células da glia (gliose) e a uma menor quantidade de linfócitos, macrófagos e raros neutrófilos. No 4 e 5 DPI, as lesões eram mais acentuadas e consistiam de manguitos perivasculares, compostos por uma a três fileiras de linfócitos, macrófagos e plasmócitos. Adicionalmente, periventriculite e meningite foram visualizadas, e eram mais acentuadas no 5 DPI. Diversas quimiocinas, incluindo a CCL-2, a qual estava significativamente aumentada nos animais infectados, principalmente no início da infecção, são responsáveis pelo recrutamento de células inflamatórias para o SNC, tais como monócitos e linfócitos T (ASENSIO; CAMPBELL, 1999). Estas quimiocinas podem ser expressas por células residentes do SNC, incluindo neurônios, micróglia e astrócitos (ASENSIO; CAMPBELL, 1999). Por outro lado, na encefalite auto-imune experimental em camundongos, a citocina IFN-y é principalmente produzida por linfócitos T CD4 ${ }^{+}$infiltrantes, ao passo que o TNF-a é principalmente expresso por macrófagos e micróglia (RENNO et al., 1995).

Resultados prévios do nosso grupo de estudo demonstraram, que quando inoculado pela via intranasal, o BoHV-5 não foi capaz de infectar o SNC de camundongos BALB/c. Nos camundongos adultos das linhagens BALB/c $\left(H 2^{d}\right)$, $\mathrm{BALB} / \mathrm{c}$ nude $\left(\mathrm{H} 2^{\mathrm{d}}\right), \mathrm{A} / \mathrm{J}\left(\mathrm{H} 2^{\mathrm{a}}\right)$ e $\mathrm{C} 3 \mathrm{H} / \mathrm{HeJ}\left(\mathrm{H} 2^{\mathrm{k}}\right)$ e inoculados pela via intranasal com o BoHV-5 não apresentaram sinais clínicos da infecção até o 4 DPI e pelo isolamento viral, não foi detectada a presença de partículas virais viáveis nos órgãos analisados (pulmão e SNC). Semelhantemente, outros isolados de BoHV-5 foram incapazes de causar doença ou infectar camundongos adultos (SILVA et al., 1999; BELTRÃO et al., 2000). Por outro lado, nos camundongos BALB/c inoculados pela via intracraniana, partículas virais viáveis foram detectadas por isolamento viral em primeira passagem até o $6 \mathrm{DPI}$. Do 1 para o 2 e $3 \mathrm{DPI}$ houve um aumento no número de partículas virais no SNC dos camundongos inoculados com o BoHV-5. O isolamento de partículas virais viáveis até o $6 \mathrm{DPI}$ associado a esse aumento no 
número de partículas detectadas por meio de qPCR absoluta, demonstra pela primeira vez que houve replicação no SNC destes camundongos wild-type. Em estudo prévio com camundongos com diversas deficiências genéticas infectados pela via intraperitoneal não foi realizado isolamento viral, e foi demonstrado indiretamente, por meio do aumento da carga viral na qPCR, que o BoHV-5 pode infectar e se replicar no SNC (ABRIL et al., 2004). Entretanto, isto foi demonstrado somente nos animais com severas deficiências genéticas, sendo que nos camundongos wild-type, replicação e evidências de infecção do SNC não foram comprovadas naquele estudo.

No presente estudo, antígenos virais de BoHV-5 estavam intimamente associados às áreas de inflamação, e os mesmos estavam localizados no neurópilo, em citoplasma de células inflamatórias, células da glia e endotélio vascular. Nas células inflamatórias o BoHV-5 estava localizado principalmente em macrófagos nas áreas de periventriculite e meningite. Em outro estudo, o vírus foi detectado no SNC de camundongos infectados pelo BoHV-5 com deficiência nos sistemas IFN $\alpha / \beta$, mas não nos animais wild-type (ABRIL et al., 2004), o que demonstra que camundongos wild-type provavelmente não são susceptíveis a infecção pelo BoHV-5 quando inoculados por outras vias, além da intracraniana. Semelhantemente ao presente estudo, em outros modelos animais, como no coelho, os antígenos de BoHV-5 foram detectados e, células endoteliais e células inflamatórias mononucleares (MACHADO et al., 2013). Entretanto, Machado et al. (2003) demonstraram a presença de antígenos de BoHV-5 em neurônios corticais, do hipocampo, diencéfalo e mesencéfalo de coelhos inoculados pela via intranasal e imunossuprimidos com dexametasona. No presente estudo, antígenos virais não foram detectados em neurônios nestas regiões.

A infecção pelo BoHV-5 em bovinos ocorre quando há inalação das partículas virais e infecção de células epiteliais, sendo que após a infecção aguda o vírus estabelece infecção latente em gânglios sensoriais, principalmente no gânglio trigeminal. Após eventos imunossupressivos ocorre reativação viral que cursa com meningo-encefalite necrotizante que geralmente é fatal (DEL MÉDICO ZAJAC et al., 2010). No presente estudo, no 6 DPI, antígenos virais foram visualizados no citoplasma de neurônios no gânglio trigeminal de camundongos BALB/c inoculados com BoHV-5. A presença do BoHV-5 no gânglio trigeminal foi confirmada por meio de qPCR absoluta, pela qual foi possível detectar um grande número de partículas 
virais no gânglio trigeminal. Estes resultados demonstram que o vírus foi capaz de infectar neurônios do gânglio trigeminal, o que pode indicar um possível estabelecimento de infecção latente. Entretanto, ainda são necessários mais estudos que comprovem se o BoHV-5 foi capaz de estabelecer infecção latente em camundongos e se o recrudescimento pode ocorrer com eventos imunossupressivos posteriores. Em bovinos experimentalmente infectados pelo BoHV-5 pela via intranasal, o primeiro aparecimento de lesões no gânglio trigeminal se deu no 7 DPI (PEREZ et al., 2002). No presente estudo, lesões significativas não foram detectadas no gânglio trigeminal. Além do gânglio trigeminal, outros locais podem servir de latência para o BoHV-5. Na infecção latente pelo BoHV-5 em coelhos, o DNA de BoHV-5 foi detectado em outras áreas tais como cerebelo e córtex cerebral (MAYER et al., 2006). Semelhantemente, em bovinos, outras áreas do SNC, tais como mesencéfalo, córtex olfatório, córtex frontal, e bulbo olfatório, possivelmente podem servir de latência para o BoHV-5 além do gânglio trigeminal (VOGEL et al., 2003).

No presente estudo, os camundongos infectados pelo BoHV-5, sobreviveram à infecção até o 15 DPI. Após o 10 DPI lesões significativas não foram visualizadas no SNC, bem como partículas virais viáveis não foram detectadas após o $6 \mathrm{DPI}$, o que demonstra que os camundongos da linhagem BALB/c foram capazes de debelar a infecção aguda, mesmo quando inoculados pela via intracraniana. Muito provavelmente as citocinas e quimiocina detectadas no SNC destes animais nos primeiros dias da infecção, tais como IFN-y, TNF-a e CCL-2, contribuíram para o controle da infecção aguda nestes animais.

\subsection{CONCLUSÕES}

O BoHV-5 quando inoculado pela via intracraniana foi capaz de infectar e se replicar no SNC de camundongos BALB/c. Entretanto, estes animais foram capazes de debelar a infecção aguda associado a uma resposta imune do tipo Th1, com expressão das citocinas IFN- $\gamma$, TNF- $\alpha$, além da quimiocina CCL-2. Muito provavelmente a expressão destas citocinas e quimiocina, principalmente no início da infecção (3 e 4 DPI), contribuíram para o desenvolvimento da encefalite e para a 
eliminação do vírus, uma vez que partículas virais viáveis não foram detectadas após o $6 \mathrm{DPI}$. Entretanto, grande quantidade do DNA de BoHV-5 foi detectada no gânglio trigeminal no $3 \mathrm{DPI}$, confirmado pela presença de antígenos virais no citoplasma de neurônios no 6 DPI, demonstrando que o BoHV-5 pode estabelecer uma infecção latente neste gânglio em camundongos BALB/c. 


\section{REFERÊNCIAS}

ABRIL, C.; ENGELS, M.; LIMAN, A.; HILBE, M.; ALBINI, S.; FRANCHINI, M.; SUTER, M.; ACKERMAN, M. Both viral and host factors contribute to neurovirulence of Bovine Herpesviruses 1 and 5 in Interferon Receptor-deficient mice. Journal of Virology, v. 78, n. 7, p. 3644-3653, 2004.

ASENSIO, V. C.; CAMPBELL, I. L. Chemokines in the CNS: plurifunctional mediators in diverse states. Trends in Neuroscience, v. 22, n. 11, p. 504-512, 1999.

BELTRÃO, N.; FLORES, E. F.; WEIBLEN, R.; SILVA, A. M.; ROEHE, P. M.; IRIGOYEN, L. F. Infecção e enfermidade neurológica pelo herpesvírus bovino tipo 5 (BHV-5): coelhos como modelo experimental. Pesquisa Veterinária Brasileira, v. 20, n. 4, p. 144-150, 2000.

CANTIN, E. M.; HINTON, D. R.; CHEN, J.; OPENSHAW, H. Gamma interferon expression during acute and latent nervous system infection by herpes simplex virus type 1. Journal of Virology, v. 69, n. 8, p. 4898-4905, 1995.

DEL MÉDICO ZAJAC, M. P.; LADELFA, M. F.; KOTSIAS, F.; MUYLKENS, B.; THIRY, J.; THIRY, E.; ROMERA, S. A. Biology of bovine herpesvirus 5. The Veterinary Journal, v. 184, p. 138-145, 2010.

DIALLO, I. S.; CORNEY, B. G.; RODWELL, B. J. Detection and differentiation of bovine herpesvirus 1 and 5 using a multiplex real-time polymerase chain reaction. Jounal of Virological Methods, v. 175, n. 1, p. 46-52, 2011

HUBNER, S. O.; PESCADOR, C.; COBERLLINI, L. G.; DRIEMEIER, D.; SPILKI, F. R.; ROEHE, P. M. Otimização da imuno-histoquímica para detecção de herpesvírus bovino tipo 5 (BHV-5) em tecidos do sistema nervoso central fixados em formaldeído. Arquivo Brasileiro de Medicina Veterinária e Zootecnia, v. 57, n. 1, p. 1-6, 2005.

LIBBEY, J.E.; KENNETT, N.J.; WILCOX, K.S.; WHITE, H.S.; FUJINAMI, R.S. Interleukin-6, produced by resident cells of the central nervous system and infiltrating cells, contributes to the development of seizures following viral infection. Journal of Virology, v. 85, p. 6913-6922, 2011.

MACHADO, G. F.; BERNARDI, F.; HOSOMI, F. Y. M.; PEIRÓ, J. R.; WEIBLEN, R.; ROEHE, P. M.; ALESSI, A. C.; MELO, G. D.; RAMOS, A. T.; MAIORKA, P. C. Bovine 
herpesvirus-5 infection in a rabbit experimental model: immunohistochemical study of cellular response in the CNS. Microbial pathogenesis, v. 57, p. 10-16, 2013.

MAYER, S. V.; QUADROS, V. L.; VOGEL, F. S. F.; WINKELMAN, E. R.; AREHART, S.; WEIBLEN, R.; FLORES, E. F. Dexamethasone-induced reactivation of bovine herpesvirus type 5 latent infection in experimentally infected rabbits results in a broader distribution of latent viral DNA in the brain. Brazilian Journal of Medical and Biological Research, v. 39, n. 3, p. 335-343, 2006.

MORI, C. M. C.; MORI, E.; FAVARO, L. L.; SANTOS, C. R.; LARA, M. C. C. S. H.; VILLALOBOS, E. M. C.; CUNHA, E. M. S.; BRANDÃO, P. E.; RICHTZENHAIN, L. J.; MAIORKA, P.C. Equid Herpesvirus type-1 exhibits neurotropism and neurovirulence in a mouse model. Journal of Comparative Pathology, v. 146, p. 202-210, 2012.

NATIONAL RESEARCH COUNCIL (NRC). Guide for the care and use of laboratory animals. $8^{\text {th }}$ ed. Washington D.C.: National Academy Press, 2010. 248 p.

PEREZ, S. E.; BRETSCHNEIDER, G.; LEUNDA, M. R.; OSORIO, F. A.; FLORES, E. F.; ODEÓN, A. C. Primary infection, latency and reactivation of bovine herpesvirus type 5 in the bovine nervous system. Veterinary Pathology, v. 39, n. 4, p. 437-444, 2002.

REED, L. J.; MUENCH, H. A simple method of estimating fifty per cent endpoints. The American Journal of Hygiene, v. 27, p. 493-497, 1938.

RENNO, T.; KRAKOWSKI, M.; PICCIRILLO, C.; LIN, J. Y.; OWENS, T. TNF-alpha by resident microglia and infiltrating leukocytes in the central nervous system of mice with experimental allergic encephalomyelitis. Regulation by Th1 cytokines. The Journal of Immunology, v. 154, p. 944-953.

RISSI, D. R.; BARROS, C. S. L. Necrotizing meningoencephalitis in a cow. Veterinary Pathology, v. 50, n. 5, p. 926-929, 2013.

SILVA, A. M.; FLORES, E. F.; WEIBLEN, R.; CANTO, M. C.; IRIGOYEN, L. F.; ROEHE, P. M.; SOUZA, R.S. Pathogenesis of meningoencephalitis in rabbits by bovine herpesvirus type-5 (BHV-5). Revista Brasileira de Microbiologia, v. 30, p. 22-31, 1999.

STEIBEL, J. P.; POLETTO, R.; COUSSENS, P. M.; ROSA, G. J. M. A powerful and flexible linear mixed model framework for the analysis of relative quantification RTPCR data. Methods, v. 94, p. 146-152, 2009. 
VOGEL, F. S. F.; CARON, L.; FLORES, E. F.; WEIBLEN, R.; WINKELMAN, E. R; MAYER, S. V.; BASTOS, R. G. Distribution of bovine herpesvirus type 5 DNA in the central nervous systems of latently, experimentally infected calves. Journal of Clinical Microbiology, v. 41, n. 10, p. 4512-4520, 2003. 


\section{CONCLUSÃO GERAL}

As quimiocinas RANTES (CCL-5) e MCP-1 (CCL-2) são expressas por diferentes células residentes do sistema nervoso central (SNC) no bulbo olfatório (BO) durante a infecção causada pelo vírus da estomatite vesicular sorotipo New Jersey (VEVNJ) em ratos-veadeiros. Neurônios, astrócitos e micróglia expressaram RANTES, ao passo que MCP-1 foi expresso por neurônios e astrócitos. A disseminação viral nos neurônios do BO procedeu a expressão destas quimiocinas, demonstrando que os neurônios infectados exercem um papel importante na iniciação da resposta imune no BO. Apesarem de não estarem significativamente infectados pelo VEVNJ, os astrócitos e a micróglia também responderam à infecção ao expressarem quimiocinas.

O herpesvírus bovino tipo 5 (BoHV-5) foi capaz de infectar e se replicar no SNC de camundongos BALB/c por meio da via intracraniana. Entretanto, os camundongos infectados foram capazes de debelar a infecção aguda, o que estava associado a uma resposta imune do tipo Th1, com expressão das citocinas IFN- $\gamma$, TNF- $\alpha$, além da quimiocina CCL-2. A expressão destas citocinas e quimiocina, principalmente no início da infecção (3 e 4 DPI), muito provavelmente contribuíram para o desenvolvimento da encefalite e para a eliminação do vírus, uma vez que partículas virais viáveis não foram detectadas após o 6 DPI. Apesar dos camundongos infectados terem eliminado o BoHV-5 durante a infecção aguda, grande quantidade do DNA de BoHV-5 foi detectada no gânglio trigeminal no 3 DPI, confirmado pela presença de antígenos virais no citoplasma de neurônios no 6 DPI. Estes resultados demonstram que o BoHV-5 possivelmente estabelece uma infecção latente no gânglio trigeminal em camundongos BALB/c. 